\title{
THE NUMBERS GAME: ESTIMATES OF ILLEGAL ALIENS IN THE UNITED STATES, 1970-1981
}

\author{
ARTHUR F. CORWIN*
}

I

\section{INTRODUCTION}

Many of the fundamental decisions about immigration reform in this country hinge on questions of numbers. How many illegal aliens are there? How many might qualify for this or that amnesty date or for permanent work permits? If amnestied aliens send for relatives, what might be the rate of exponential immigration growth? If an estimated $60 \%$ or more of all deportable aliens are of Mexican origin would a similar percentage show up in the number of aliens that might be legalized? Should Mexico be given a special high number of immigration visas to help absorb illegal entrants? If local governments should be compensated for social assistance costs resulting from a legalization program, on what estimated numbers should such compensation be based? If illegal aliens are "undocumented" taxpayers and make less use of social assistance, as some pro-amnesty groups claim, how should that consideration be weighed quantitatively into a compensation formula?

These and other related questions are of such magnitude that they justify a broad survey of what is known, or not known, about illegal alien numbers in the United States. This study seeks to provide just such a global picture of the controversial subject by tracking the development of the "numbers game" in a loosely chronological frame. Within that structure, the topic is subdivided into several major areas of interest.

Section II provides a brief history of how, in the early 1970's, illegal aliens first came to be seen as a "numbers problem" as legislators sought some statistical guidance on what to do about "undocumented" workers and residents. This section suggests how the "politics" of the numbers game first emerged. Section III describes initial responses to the numbers problem by the Immigration and Naturalization Service (INS). Subsequent sections describe the emergence of a new and flourishing field of research and speculation concerning the number of illegal aliens. The methodologies into which such studies can be conveniently divided are also suggested, for example, analytical/residual estimates in section IV, speculative estimates in section $\mathrm{V},{ }^{1}$ and socioeconomic profiles of illegal aliens in section VI. ${ }^{2}$

\footnotetext{
Copyright (C) 1983 by Law and Contemporary Problems

* Independent researcher and writer on immigration subjects who served as an immigration consultant to the House Judiciary Committee 1981-82.

1. The methodological problems inherent in any attempt to size up "hidden populations" are conve-
} 
Section VII looks at the numbers game from the Mexican side of the river, which is important because data from below the border is a fundamental source of information for demographers and social scientists seeking to measure the migration of "undocumented" Spanish language groups. Of course, in the interest of brevity, some studies of the number of illegal aliens in the United States could not be considered in this survey.

Section VIII includes an account of the controversy surrounding the 1980 Census and its findings. The census is an integral part of the development of the disputatious numbers game, mainly because of its importance in formulating representation and welfare state policies. Finally, section IX describes the legislative dilemma resulting from a lack of firm statistical information on the size of the illegal alien population.

II

\section{"How Many Are We Talking About Commissioner?"-The EMERGENCE OF THE "NUMBERS GAME"}

By 1965 the Johnson administration (1963-1968), under the banner theme of the Great Society, had committed a then-affluent nation to a domestic war on poverty. ${ }^{3}$ Just as Great Society programs began to reduce the mobility and job

TABLE 1

Deportable Aliens located For Fiscal Years JULY 1 TO JUNE 30

\begin{tabular}{rr}
\hline 1964 & 86,597 \\
1965 & 110,371 \\
1966 & 139,520 \\
1967 & 161,608 \\
1968 & 212,057 \\
1969 & 283,557 \\
1970 & 345,353 \\
\hline
\end{tabular}

Soutce: IMMIGRATION AND NATURalization SERVICE, U.S. DEP'T of Justice, AnNual Report Tables 27B \& 33 (1964-1970).

niently summarized in U.S. General accounting Office, Problems and Options in Estimating; the Size of the Illegal alien Population, Report to the Chairman of the Committee on the JUDICIARY (1980) (prepared at the request of Sen. Alan Simpson).

2. A guide to other academic works that seek to assess the socioeconomic impact of "undocumented" immigrants may be found in J. Vialet, Illegal Aliens: ANalysis and Background (1977) (available from Congressional Research Service, U.S. Library of Congress with updates). See also STAFF OF SELECT Comm'n on Immigration and Refugee Policy, 97th CONG., 1st Sess., Final Report: U.S. ImMigration Policy and the National Interest (Comm. Print 1981) [hereinafter cited as SCIRP Final Report]; U.S. ImMigration POlicy and the National Interest: APPendix E to Staff Report of the Select Comm'n on Immigration and Refugee Policy, Papers on Illegal Migration to the United States AND APPEndices (1980) (Supplement to SCIRP Final RePORT) [hereinafter cited as Appendix E to SCIRP FINAL REPORT].

3. Lyndon B. Johnson, Annual Message to the Congress on the State of the Union, 1965 PUB. PAPERS 1-9 (Jan. 4); Lyndon B. Johnson, Remarks at the University of Michigan, 1964 PUB. PAPERS 704-06 (May 22). 
needs of various sectors of the American labor force, and as America's manpower became increasingly committed to an undeclared war in Vietnam, the Mexican contract labor program (also known as the Bracero program) was allowed to lapse. American contractors and employers, encountering this war on two fronts, increasingly turned to illegal labor from Mexico and other countries. This is roughly indicated by the rapid rise in the number of illegal aliens apprehended by the U.S. Immigration and Naturalization Service (INS).

Since the INS concentrated most of its enforcement personnel in areas bordering on Mexico, from $80 \%$ to $90 \%$ of the apprehensions involved Mexican nationals, many of them "repeaters" seeking seasonal jobs in the United States." But immigration directors and investigators in the district offices of the interior were also keenly aware that non-Mexican illegals were slipping into the country in ever larger numbers, usually as tourists and visitors arriving on international airflights, or through other sophisticated smuggling channels. One had only to look around at the new alien labor force in American cities to find visible proof that the control problem was no longer strictly a Mexican border problem. ${ }^{5}$

A surge of complaints reached Congress that illegal aliens and "new-style wetbacks" were undermining Great Society job training programs for America's disadvantaged minorities, and were nullifying efforts to unionize farm labor and certain jobs in the secondary labor market, such as garment workers. ${ }^{6}$ Employers were accused of greedily using cheap immigrant labor to break strikes, and to depress wages and working conditions. ${ }^{7}$

In 1971 the House Judiciary Committee and its Subcommittee on Immigration, under Chairman Peter W. Rodino, Jr., began the most extensive series of hearings ever held on the subject of illegal aliens. ${ }^{8}$ The hearings took place all over the country and focused national attention not only on the growing problems of illegal aliens in America's economy and society, but also on the need for penalties against the employers of such aliens. Twice, in 1972 and 1975, so-called Rodino bills providing for "preventive" solutions to illegal entries and settlements were approved by the House of Representatives. Both bills were blocked by the Senate Judiciary Committee then headed by Senator James O. Eastland, who was himself a user of cheap alien labor on his Mississippi plantations. ${ }^{9}$

4. See Immigration and Naturalization Service, U.S. Dep't of Justice, Annual Report Tables 30 \& 33 1964-70.

5. See State of Illinois, Legislative Investigating Commission, Report to the General Assembly on the Illegal Mexican Alien Problem in Illinois (1971); Portes, Retum of the Wetback, SocieTY Mar.-Apr. 1974, at 40, 40-46; Wetbacks Are Heading for the Cities, Houston Post, July 27, 1969 at 12, col. 1.

6. Illegal Aliens: Hearings Before Subcomm. No. I of the House Comm. on the Judiciany, 92d Cong., ist and 2d Sess. (1971-1972) (five parts) [hereinafter cited as Rodino Hearings].

7. In particular, Cesar Chavez, head of the United Farm Workers, affiliated with the AFL-CIO, popularized the charge that employers were using illegal aliens as strike breakers. See Review of the Administration of the Immigration and Nationality Act: Hearings Before the Subcomm. on Immigration, Citizenship, and Intemational Law of the House Comm. on the Judiciary, 93d Cong., 1st Sess. 155-60 (1973).

8. Rodino Hearings, supra note 6.

9. See Controversy Over Proposals to Reduce the Number of Illegal Aliens, ConG. DiG., Jan. 1975, at 1, 1-32; Corwin, A Story of $A d$ Hoc Exemptions, in IMMIGRants--AND IMMIGRANTS: Perspectives ON MEXICAN Labor Migration to the United States 136, 136-75 (A. Corwin ed. 1978). 
The Rodino hearings highlighted the unavailability of firm estimates based on empirical research or actual head counts of illegal alien workers or residents. The Central Office of the INS could only provide apprehension statistics, which were of limited use. Otherwise the INS had only a hazy notion of how many illegals might have settled into jobs or established households. ${ }^{10}$

Nevertheless, the hapless INS was pushed by Congress to come up with an estimate of the number of foreign nationals illegally in the United States. Commissioner of Immigration Raymond Farrell, who wished to maintain the appearance that his administration (January 1962 to April 1973) had immigration matters under control, did not press Congress or the President's Office of Management and Budget for more manpower or documentary control facilities. He finally reluctantly admitted in 1972 that there could possibly be $1,000,000$ illegals in the country. ${ }^{11}$

Farrell's figure was a "guesstimate" done after a hasty consultation with district directors who were unsure whether the estimate was limited to illegal workers, or also included family members. Meanwhile, INS arrest figures surged upwards, paralleled by public complaints about illegal aliens, as can be seen in appendix $\mathrm{A}$ and in table 2 .

TABLE 2

Deportable Aliens located For Fiscal Years
July 1 TO June 30

\begin{tabular}{lll}
\hline & Mexican & Other \\
\cline { 2 - 3 } 1971 & 348,406 & 64,406 \\
1972 & 430,211 & 61,978 \\
1973 & 576,807 & 70,705 \\
1974 & 709,945 & 71,046 \\
\hline
\end{tabular}

Source: IMMIGRATION AND NATURALIZATION SERVICE, U.S. DeP'T OF JUSTICE, ANNUAL REPORT Tables 27B \& 30 (19711974).

In late 1973 the Nixon administration appointed an enforcement-minded Commissioner of Immigration, Leonard F. Chapman, Jr., a former Marine Corps general. General Chapman expressed his alarm about the inability of an understaffed immigration service to contain the flow of illegal aliens into the American labor market and into American communities. He found the Service so

10. The INS lacked, and still lacks, research capabilities and a modern documentary control system. For instance, it has never known how many legally admitted immigrants and nonimmigrants return to their home country. See U.S. General ACcOUnTing Office, RePORT by THE Comptroller General of the United States: Controls Over Nonimmigrants Remain Ineffective (1980); see also 20 Million Aliens 'Lost' in U.S. Maze, Chicago Trib., Nov. 23, 1981, at 1, col. 1 (report on the inability of an understaffed INS to keep track of millions of foreign visitors) [hereinafter cited as Chicago Tribune].

11. Rodino Hearings, supra note 6, at 1323-25; U.S. INTERAGENCY TASK FORCE ON IMMIGRATION Policy, U.S. DeP'T OF Justice, Interagency Task Force on Immigration Policy StafF RePort/Departments of Justice, LABOR AND State 384 (1979). 
undermanned and so underfunded, and its equipment so outmoded, that it could perform only minimal service and enforcement functions. In other words, there was a logistical problem.

TABLE 3

IMMigRation SERVice ResourCes

\begin{tabular}{lccc} 
Fiscal Year & 1971 & 1972 & 1973 \\
\hline Total personnel of INS & 7,230 & 6,682 & 6,682 \\
Total INS budget (in millions of \$) & 121.9 & 130.9 & 137.5 \\
\hline
\end{tabular}

Note: Apprehension and budget figures may vary.

Source: Immigration and Naturalization SERvice, U.S. DEP'T of Justice, AnNual REPORT Tables 23, 27B (1971-1973); Hearings Before Subcomm. on Commerce, Justice, and State, of the House Comm. on Appropriations, 92d Cong., 1st Sess. Pt. 1, 788 (1971); id., 92d Cong., 2d Sess. Pt. 1, 948 (1972); id. 93d Cong;, Ist Sess. Pt. 1 (1973); id. 94th Cong., 1st Sess. Pt. 4, 628-719 (1976); Immigration and Naturalization Regional Office Operations Hearings Before the Subcomm. on Legal and Monetary Affairs of the House Comm. on Government Operations, 93d Cong., 1st \& 2d Sess. (1973-74); Correspondence with Statistics Division, Central Office, Immigration and Naturalization Service, Washington, D.C.

Meanwhile, estimates of illegal aliens actually residing in the United States took a quantum leap. In October 1974, Attorney General William Saxbe, after touring the Mexican border and communities deluged with aliens, estimated the number of illegal residents to be at least between 4,000,000 and 7,000,000 and probably higher. At the same time, Commissioner Chapman, who was trying to drum up public support and appropriations for enforcement of immigration laws and inspection standards, spoke ominously of a "Silent Invasion" and gave a rough estimate of from $4,000,000$ to $12,000,000$ illegal residents. ${ }^{12}$

The numbers game had acquired a political character which has dominated estimates of illegal aliens, whether high or low, ever since. Neither the Commissioner of Immigration, nor his superior, the Attorney General, had any clear idea as to what nationalities composed the estimates, although immigration officials commonly figured that from $60 \%$ to $75 \%$ of all illegal resident aliens were Mexicans and other Hispanics. ${ }^{13}$ Accused (by Chicano and other Hispanic leaders) of using exaggerated "racist estimates" in order to justify an immigration crackdown on disadvantaged minorities ${ }^{14}$ and pressed by Congress and the administration for

12. See Chapman, Illegal Aliens: Time to Call a Halt', Reader's Dig., Oct. 1976, at 186, 186-92; N.Y. Times, Dec. 31, 1974, at 26, col. 1 (Chapman was reported to have said that the illegal alien population was at least $6,000,000$ or $7,000,000$ and might be as high as $10,000,000$ or $12,000,000$; see also W. FOGEL, Mexican Illegal Workers in THE United States 19 (Institute of Industrial Relations Monograph No. 20, 1978).

13. See Immigration 1976: Hearings on S. 3074 Before the Subcomm. on Immigration and Naturalization of the Senate Comm. on the Judiciary, 94th Cong., 2d Sess. 28, 35 (1976) [hereinafter cited as 1976 Hearings]; Corwin, Quien Sabe, Mexican Migration Statistics, in IMMIGRants-AND IMMIGRanTs: Perspectives on MeXICAN Labor Migration to the United States 108, 125-30 (A. Corwin ed. 1978).

14. Statements by Mexican, Chicano, and Anglo-American delegates at a symposium, Immigration and Public Policy: The Humanistic Imperative, sponsored by Chicano Training Center of Houston, University of Houston, in April 1977; see also Mazón, Illegal Alien Surrogates: A Psychohistorical Interpretation of Group Stereotyping in Times of Economic Stress, 6 AzTlan-InT'L J. Chicano STUd. Research 305, 305-13, $318-21$ (1975); Illegal Aliens and Scapegaats, Wall St. J., May 2, 1977, at 12, col. 1. 
more precise estimates, Chapman and other INS officials decided that it was time for the INS to search out more precise, objective estimates.

III

INS Estimates of Deportable Aliens, 1975-1976, AND Their Use

\section{A. General INS Surveys}

Prior to Commissioner Chapman's administration, the INS had never sponsored any serious research on immigrant populations or flows. Congress had never mandated this, nor had congressional appropriations provided for it. Nevertheless, Chapman decided that if Congressional committees were to be provided with needed information about the dynamics of the new waves of immigration, the INS would have to promote outside research and, to whatever extent was possible, develop its own research capabilities. Hereafter, the INS would take an active role in assessing the problems that it was charged with solving. ${ }^{15}$

As a first step, the INS contracted with Lesko Associates, a research firm, to do an independent survey of the number of illegal residents in the United States as of 1975. A panel of immigration experts and academicians, some of them associated with newly created ethnic study centers, was asked to estimate the total number of illegal aliens, and the subtotal of Mexican illegals.

Unknown to one another, the panelists evaluated each other's estimates in followup questionnaires. The estimates ranged from 2,000,000 to $12,000,000$ depending on whether the panelists primarily considered the number of illegal workers or the number of workers plus family dependents. The results were averaged and announced in October 1975 as follows: 8,200,000 illegal residents in all, of which 5,200,000 were thought to be Mexicans. ${ }^{16}$

The technique used by Lesko Associates for this survey is known as the Delphi technique and has been described as "iterative informed guesswork." 17 Both the technique and the results of the survey were the subject of scathing criticism by professional demographers. For one thing, panelists provided no systematic rationale for their estimates. For another, the panel was not balanced. Certain experts were left out, or refused to participate. ${ }^{18}$

In fairness to Lesko Associates and the INS, however, Commissioner Chapman never intended the project to be more than a preliminary survey of expert opinion

15. See Guss, Even If You're on the Right Track, You'll Get Run Over if You Just Sit There, INS REP. 51, 53 (1977).

16. Lesko Associates, Final Report: Basic Data and Guidance Required to Implement a Major Illegal Alien Study During Fiscal Year 1976, 2-3, 12, 15-16 (1975) (prepared for Office of Planning and Evaluation, INS).

17. See Siegel, Passel \& Robinson, Preliminary Review of Existing Studies of the Numbers of Illegal Residents in the United States, in Appendix to SCIRP FINAL REPORT, supra note 2, at 13, $16-17$ (report prepared for SCIRP by U.S. Census Bureau demographers) [hereinafter cited as Siegel].

18. For critiques of the Lesko survey, see Keely, Counting the Uncountable: Estimates of Undocumented Aliens in the United States, 3 Population \& Dev. Rev. 447, 447-78 (1977); K. Roberts, M. Conroy, A. King, \& J. Rizo-Patron, The Mexican Numbers Game: An Analysis of the Lesko Estimate of Undocumented Migration from Mexico to the United States, Research Report (Apr. 1978) (available from Bureau of Business Research, University of Texas at Austin). 
confirming the existence of a serious alien problem in the nation, and pointing the way toward needed empirical studies of illegal aliens. The survey served both of these purposes very well.

A second step toward a general survey of the size of the illegal alien population was taken when Commissioner Chapman ordered the district directors to make a careful estimate by a consensus method of the number of aliens, including family dependents, working or residing illegally in each district. ${ }^{19}$ Each district director gathered estimates primarily from his regular staff of experienced investigators, but in some cases supplemented by estimates from border patrol agents, immigrant inspectors, and local law enforcement authorities. Most of these officers worked daily in immigrant communities and were considered to be the closest thing to "field experts" best able to judge numbers. District officials also considered, in varying degrees, apprehension statistics for iliegals captured in transit, in residence, or at a place of employment, as well as rough estimates of escape ratios and voluntary return rates to the home country. ${ }^{20}$

The district-by-district survey came up with a consensus of estimates for each district, resulting in a total estimate of 5,500,000 to 6,000,000 illegal aliens in the United States as of late $1975 .^{21}$ These results were presented to Congressional committees in early 1976.22 While Census Bureau demographers criticized the 1975 INS survey as lacking any statistical methodology other than "synthetic speculation," 23 the survey, for all its lack of uniform procedures, may still be the most realistic estimate by experienced people of the illegal alien population for a given date. The results are included in table 4.

As the recession deepened and the American economy headed toward a nine percent unemployment rate, the Ford administration (1974-1976), worried about immigrant competition in a shrinking job market and public reaction, declared illegal aliens a "national problem."24 The administration and Congress now urgently wanted statistics on illegal workers. Seeing the recession as an opportune time to substantiate the need for immigration reform and increased INS funding, Commissioner Chapman urged district directors to make a survey of employed illegal aliens similar to the 1975 district-by-district estimates of illegal alien residents. ${ }^{25}$ Field offices were also directed to collect, tabulate, and circulate wage and employment data on illegal aliens, as seen below in section VI, Socioeconomic Profiles of Illegal Aliens.

19. Telephone interview with Robert Anderson, Office of Planning and Evaluation, INS (Oct. 13, 1981); Telephone interview with Edwin Chauvin, Jr., Chairman, Association of Immigration Directors, New Orleans (Nov. 13, 1981).

20. Id.

21. Id.

22. 1976 Hearings, supra note 13 , at 39-41.

23. Keely, supra note 18, at 474-75; Siegel, supra note 17, at 17.

24. See Corwin \& Fogel, Shadow Labor Force, in IMMIGRANTS-AND IMMIGRANTs: PERsPECTIVES ON Mexican labor Migration to.THe United States 257, 280-82 (A. Corwin ed. 1978).

25. For a critique of Chapman's estimates and his motivations, see Keely, supra note 18, at 477 . See also Keely, The Shadows of Invisible People: Estimating the Number of Illegal Migrants, AM. DEMOGRAPHICS, Mar. 1980, at 24, 26-29. 
TABLE 4

Estimated Total Number of Illegal Aliens by Immigration

DISTRICTS, 1975

\begin{tabular}{lrr} 
Western Region & & \\
\hline Honolulu & $1,500-$ & 1,600 \\
Los Angeles & $1,350,000-1,500,000$ \\
Phoenix & $50,000-$ & 55,000 \\
San Francisco & $220,000-$ & 240,000 \\
Southem Region & & \\
\hline Atlanta & $75,000-$ & 80,000 \\
El Paso & $75,000-$ & 80,000 \\
Houston & $525,000-$ & 550,000 \\
Miami & $360,000-$ & 380,000 \\
New Orleans & $40,000-$ & 50,000 \\
San Antonio & $310,000-$ & 330,000 \\
Northern Region & & \\
\hline Anchorage & $600-$ & 700 \\
Chicago & $375,000-$ & 400,000 \\
Cleveland & $75,000-$ & 80,000 \\
Denver & $30,000-$ & 35,000 \\
Detroit & $50,000-$ & 60,000 \\
Helena & $2,000-$ & 3,000 \\
Kansas City & $10,000-$ & 12,000 \\
Omaha & $6,000-$ & 7,000 \\
Portland, Ore. & $25,000-$ & 30,000 \\
St. Paul & $6,000-$ & 7,000 \\
Seattle & $10,000-$ & 12,000 \\
Eastem Region & & \\
\hline Baltimore & $60,000-$ & 70,000 \\
Boston & $10,000-$ & 15,000 \\
Buffalo & $10,000-$ & 15,000 \\
Hartford & $7,000-$ & 8,000 \\
Newark & $275,000-$ & 300,000 \\
New York & $1,350,000-1,500,000$ \\
Philadelphia & $80,000-$ & 90,000 \\
Portland, Me. & $3,000-$ & 3,000 \\
San Juan & $10,000-$ & 15,000 \\
St. Albans & $500-$ & 600 \\
Washington, D.C. & $50,000-$ & 60,000 \\
Estimated Total & $5,451,600-5,989,900$ \\
\hline Sort & & \\
\hline & &
\end{tabular}

Source: Immigration 1976: Hearings on S. 3074 Before the Subcomm. on Immigration and Naturalization of the Senate Judiciary Comm., 94th Cong., 2d Sess. 39-41 (1976).

By the astute use of plausible statistical estimates, and a whirlwind public relations campaign that explained the control problem and immigration needs to powerful lobbying groups such as the American Legion and the AFL/CIO, Commissioner Chapman, with assistance from understanding Congressmen, was able to bring about a considerable improvement in the pathetic resources of the INS. Chapman was able to achieve an increase in the total number of authorized personnel for the INS and annual budget increases from 1974 to 1977. As the INS budget grew so did apprehension totals, as shown in table 5. 
TABLE 5

Alien Arrests and Immigration Service Resources

\begin{tabular}{lrrrr}
\hline Fiscal Year & 1974 & 1975 & \multicolumn{1}{c}{1976} & \multicolumn{1}{c}{1977} \\
\hline Total alien apprehensions & 788,145 & $766,600^{*}$ & 866,433 & $1,042,215$ \\
Total Mexican apprehensions & 709,959 & 680,392 & 781,438 & 954,778 \\
Total personnel of INS $\dagger$ & 7,982 & 8,082 & 8,882 & 9,473 \\
Total INS budget (Millions of \$) & 155.2 & 181.3 & 213.6 & 245.0 \\
\hline
\end{tabular}

* Depth of economic recession, apprehensions down.

†Authorized positions but not always filled for lack of funding.

Note: Apprehension and budget figures may vary.

Source: Immigration and Naturalization Service, U.S. Dep't or Justice, Annual REPORT Tables 23, 27B (1974-1977); Data from Statistical Division, Central Office, INS. With a new alien rush underway following the amnesty promises of 1977 by President Carter, INS personnel numbered 10,071 in fiscal 1978 and the INS budget totaled $\$ 266$ million.

The resources and responsibilities of the INS should be compared to other federal agencies. For example, the FBI in fiscal 1978 had $\$ 500$ million and 19,000 employees, and the Environmental Protection Agency $\$ 849$ million and 10,200 employees.

Chapman had hoped for more. Yet, taking into account rampant inflation and the overwhelming demands on immigration services and enforcement functions during his administration, he left the INS relatively well-off in fiscal 1977 compared to fiscal 1974, as seen in appendix B, INS: Staffing Levels Since Fiscal Year 1977.

\section{B. Fraudulent Entrants Study of 1975}

In September 1975, Commissioner Chapman established a Social Science Research Branch in the Office of Planning and Evaluation of the INS. Through this office, no longer operational, the INS for the first and only time thus far sponsored a major research program for the study of illegal aliens and related enforcement needs. ${ }^{26}$

The first studies conducted under the new research program were enforcement experiments funded by the Law Enforcement Assistance Administration. They were designed to suggest the size of the illegal alien flow through data collected from both electronic sensors along the Mexican border and from various deployment patterns of border patrol squadrons along common crossing points. ${ }^{27}$ Part of the design included a Fraudulent Entrants Study. Because this study was the first serious effort to measure empirically the illegal flow of documented aliens through

26. This project was done in consultation with David $\mathbf{S}$. North, an immigration and labor-use specialist who is now Vice President of the New Transcentury Foundation, a nonprofit research and consultant firm, and with the special assistance of Marion Houstoun, now with the Economic Research Division of the U.S. Dept. of Labor. Telephone interview with Marion Houstoun, Immigration Staff Specialist, Bureau of International Labor Affairs, U.S. Dep't of Labor (Nov. 14, 1981).

27. Telephone interview with Robert Anderson, supra note 19. 
inspection points, and because its findings are virtually the only sound basis for current estimates and guesses as to the size of this flow, the Fraudulent Entrants Study deserves special attention from immigration students.

\section{Methodology and Results}

The flow study was designed to provide statistically valid estimates of illegal aliens and aliens with mala fide intentions who passed through ports of entry on the Mexican border and through the largest international airports in the United States. ${ }^{28}$

Three groups of illegal entrants were studied; first, those attempting entry with counterfeit or altered documents; second, imposters, using false verbal or documented claims to American citizenship; and, third, those presenting valid documents, such as a tourist visa, a border-shopping card, or a student visa, the terms of which the bearer intended to violate after entry, usually by taking a job. Additionally, the Fraudulent Entrants Study sought information on the characteristics of fraudulent entries by time, place, and techniques used. ${ }^{29}$

The study, prepared mainly by researcher David S. North of the New Transcentury Foundation, was conducted from September 1975 to February 1976 by two teams, each comprised of four immigration inspectors. One team inspected a random sample of entrants at ten major international airports in the United States, and the other team inspected a random sample of entrants at the twelve busiest ports of entry on the Mexican border. Both teams used routine inspection techniques and questions. However, since both teams were relieved of the usual hectic inspection pressures they were able to make more thorough inspections. Because the number of mala fide applicants for admission was estimated to be relatively small compared with the many millions of annual entries, a sample of some 240,000 persons was determined to be a statistically valid sample.

During the course of the study, the two close-inspection teams denied entry to between twelve and fourteen times the number of applicants denied entry under routine inspection procedures. There were 709 mala fide applicants identified by the land team for 203,658 admissions, a ratio of 1 to 287 , and 185 mala fide applicants at airports for 38,808 admissions, a ratio of 1 to 210 .

28. Telephone interview with Lisa Roney, Office of Planning and Evaluation, INS (Oct. 13, 1981). According to Roney, who helped plan and direct the study, Canadian land border ports were excluded because Canadian citizens are not required to have border-crossing documents and because relatively few illegal aliens enter the United States there compared with the Mexican border, and because there was a plan, not carried out, to do a supplementary survey of that border. Sea ports were not surveyed because they represented only an estimated $1 \%$ of fraudulent entries.

29. See Office of Planning and Evaluation, Immigration and Naturlization Service, U.S. Dep't of Justice, Illegal Alien Study, Part 1: Fraudulent Entrant Study, a Study of Mala Fide Applicants for Admission at Selected Airports and Southwest Border Ports (1976). 


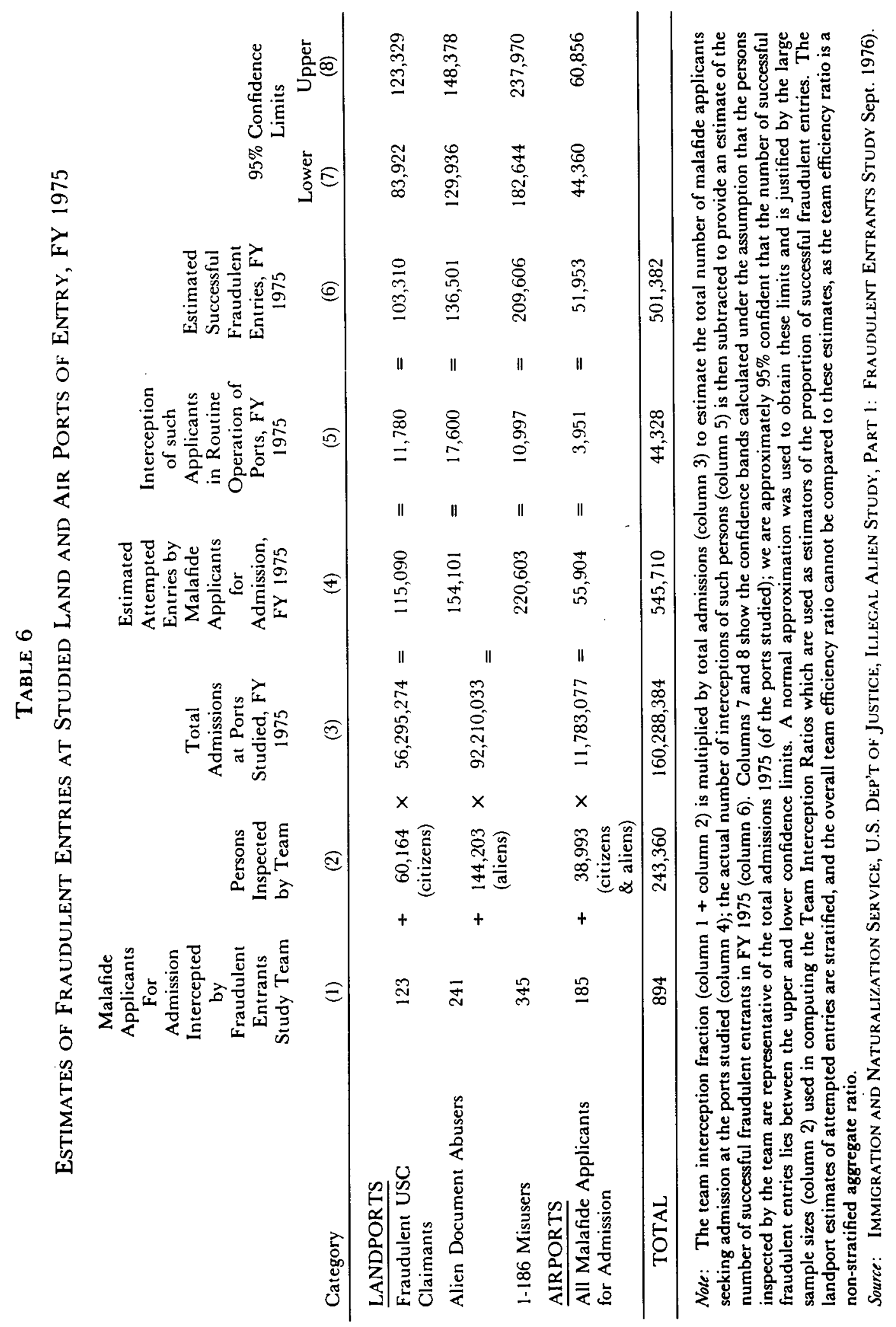


The border team found that $55 \%$ of its mala fide applicants were women. The average age of all mala fide applicants detected was twenty-seven to twenty-eight years, and almost one-quarter of the mala fide entries occurred on Saturdays (suggesting a pattern of going back and forth to jobs in the border states). At the airports, $55 \%$ of mala fide applicants intercepted were men, and the average age was thirty years. Some $71 \%$ of this group came from Caribbean countries. The majority of this group carried valid nonimmigrant visas, but many intended to seek or return to jobs or to settle with relatives in the United States. ${ }^{30}$

Based on the results of the two teams, in excess of 500,000 mala fide applicants were projected to have successfully entered through the studied ports during fiscal 1975 , roughly 450,000 at land ports, and 50,000 at international airports. One must carefully note, however, that the foregoing projection represents only mala fide entries and not necessarily the population of illegal entrants.

\section{Present Validity of the Study}

In order to maintain its relevance, the 1975 Fraudulent Entrants Study should be updated, and based, if possible, on a larger sample for several reasons. ${ }^{31}$ First, the number of aliens and returning U.S. citizens admitted through all American ports of entry and international airports continues to grow by millions each year, suggesting an overwhelming workload for immigration and customs inspectors. In fiscal 1978, for instance, 103,000,000 aliens (many of them repeat visitors) and 60,000,000 U.S. citizens (mostly Mexican-Americans and Anglo-American tourists) were admitted through Mexican border ports. Similarly, over the Canadian border 51,700,000 aliens were admitted to the United States and 36,000,000 American citizens crossed into Canada. Also admitted in 1978 were some 9,300,000 nonimmigrant aliens from all parts of the world, arriving mostly at international airports. ${ }^{32}$ Immigration inspectors, who curiently number less than 1,350 , believe that the percentage of fraudulent and mala fide entrants through ports of entry has steadily gone up since 1975, and that the number entering through airports alone may now be at least several hundred thousand a year. ${ }^{33}$

Second, an overwhelming percentage of all apprehensions are Mexican, Latin American, and other aliens attempting to enter by way of Mexico. The number of illegal aliens who successfully enter at international airports or through Canadian ports of entry with fraudulent documents or with mala fide intentions, if known, would undoubtedly change the proportions of the table.

30. Id. at viii-ix.

31. According to David S. North, Center for Labor and Migration Studies, New Transcentury Foundation, Washington, D.C. (Nov. 6, 1981) (telephone memo); see also Keely, supra note 18, at 475.

32. IMmigration and Naturalization SERVice, U.S. Dep't Of JUSTICE, STATISTICal YearboOK OF THE IMMIGRATION AND NATURALIzATION SERVICE 42, 58 (1978); see also Chicago Trib., supra note 10.

33. Interviews with immigration officers in 24 district offices and substations, and with border patrolmen in seven sectors during twelve-week tour of midwestern and southwestern states (Mar. 1 to Apr. 10, and May 1 to June 15, 1981); see also Telephone interview with Michael G. Harpold, President, Immigration and Naturalization Service Council, American Federation of Government Employees (Oct. 2, 1981). 


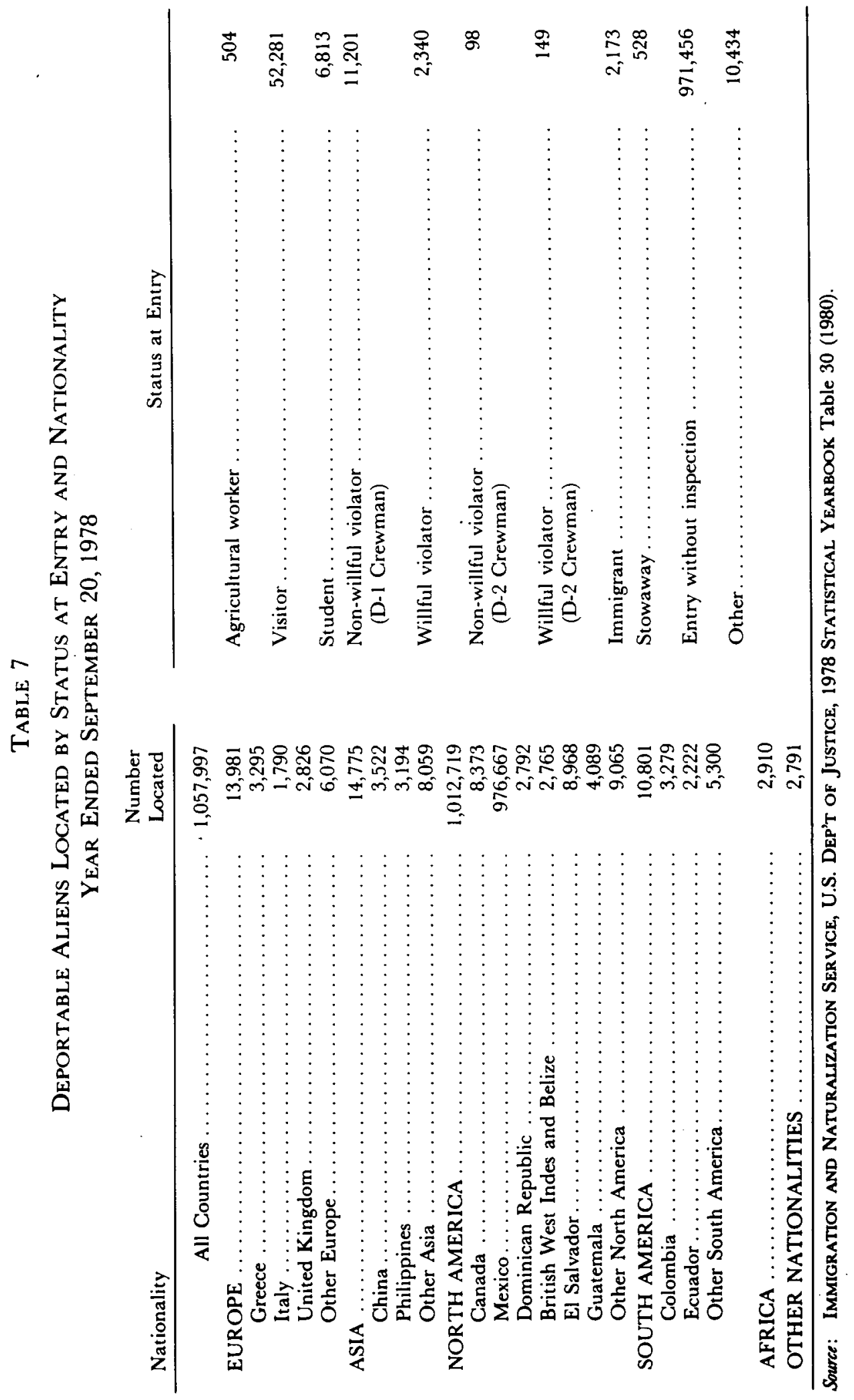


Third, "Entries Without Inspections" (EWI's) can be a very misleading figure. Many illegals pass through ports of inspection with documents, but once in the United States they often hide the entry document and take an assumed name, because if they were apprehended with the document they could be subject to felony charges ${ }^{34}$ and, in any case, the entry document would be confiscated. Consequently, when fraudulent entrants are picked up, they commonly reply that they crossed the border avoiding inspection ports. They are then usually given a nonpenalty voluntary departure, and soon after can use the same hidden document to return through an entry port where inspection is minimal because of manpower shortages in the INS. Those shortages can be seen in appendices $B$ and $C$.

The distribution of apprehended aliens for a recent year is given in the table below, which also roughly indicates the countries from which illegal aliens most commonly come, but not necessarily the real proportions.

\section{The Reyes Residential Survey of Illegal Aliens}

By 1976 the subject of "how many illegal aliens?" was enveloped in a fog of conflicting estimates and interpretations. Many federal legislators and top immigration officials believed it was high time for a headcount of illegal residents. If such a count could be taken, its results might cut through an impasse and prepare the way for enlightened legislative or enforcement measures.

Consultant David S. North proposed a residential survey and indicated how it might be done. Commissioner Chapman saw this proposal as a logical culmination of illegal alien research studies fostered by his administration, and therefore pushed the idea before the interagency Domestic Council on Illegal Aliens, a group appointed by the Ford administration. ${ }^{35}$ By then, proposals of mass amnesty were floating in the air. ${ }^{36}$ The Council agreed that before endorsing such a radical solution more precise information about the number and nature of the possible beneficiaries would be needed. The Council therefore approved the survey on the understanding that it could be completed in one year. ${ }^{37}$ Congress agreed, and in fiscal 1976 gave the INS $\$ 1,000,000$ to cover contract costs. Never before had the INS had such a windfall to invest in immigration study.

The objectives of the residential survey were: (1) to estimate the number of illegal aliens by type (for example, entrant without inspection, visa abuser, mala fide applicant, or falsely documented) in selected areas in the twelve most populous states where, it was assumed, the majority of illegals would be found, namely: California, Texas, Illinois, Indiana, Ohio, Michigan, Pennsylvania, New York, New Jersey, North Carolina, and Florida; (2) to collect and analyze information

34. Immigration and Nationality Act, 8 U.S.C. $\$ \S 1306,1325$ (Supp. IV 1980).

35. Telephone interview with Lisa Roney, Office of Planning and Evaluation, INS (Nov. 14, 1981).

36. See S. 561, 94th Cong., 1st Sess. (1975), Cong. ReC. S2454; U.S. DOMestic Council Comm. ON Illegal Aliens [Executive Office of the President], Preliminary Report Domestic Council. Comm. ON Illegal Aliens December 1976, at 242-43 (1976).

37. U.S. Comptroller General (GAO), Review of the Contract of the U.S. Immigration and Naturalization Service with J.A. Associates, Inc. (1978) (prepared for Joshua Eilberg, Chairman, House Subcommittee on Immigration, Citizenship, and International Law) [hereinafter cited as Report of the Comptroller General]. 
on the characteristics of illegal aliens, such as age, sex, nationality, education, mode of entry, length of stay, type of job, source of livelihood, size of family; (3) to determine the extent to which illegal residents made use of social services; and (4) to suggest further lines of research. ${ }^{38}$ The rationale for sampling immigrant communities in twelve populous states was based on a "clustering hypothesis" which assumes that illegal aliens naturally tend to live in neighborhoods where there is already a concentration of legal aliens of the same or similar ethnic origin. ${ }^{39}$

After hasty competitive bidding, the contract was awarded to J.A. Reyes Associates, a Mexican-American research firm based in Washington, D.C. Emphasizing that illegal aliens would rather run than be counted, Joseph Reyes convinced immigration officials that his mostly Hispanic group understood the people in question (presumably mostly Mexicans and other Hispanics) and thus could gain their confidence. As a condition of success, however, he insisted that the INS suspend all area control operations in the neighborhoods under study. ${ }^{40}$

Reyes Associates, counting on technical assistance from the INS and other government agencies, and on neighborhood cooperation from parish priests and other social outreach agencies such as the community development agencies set up by the War on Poverty, proposed to send teams of trained researchers through immigrant colonies. Their goal sounded somewhat like "the impossible dream," said an immigration employee, for they were to gather 100,000 interviews in twelve months from legal and illegal residents alike, 10,000 in phase I, the test phase, and the remainder in phase II.

The Reyes contract initially amounted to $\$ 751,000$. Later, the Department of Health, Education and Welfare added $\$ 80,000$ for research on the use of social service programs by illegal aliens. Another $\$ 147,000$ was spent on a separate contract for management and technical assistance. No additional funding was available from other government departments, in part because the Reyes design seemed too ambitious. ${ }^{41}$

In the fall of 1977 , a preliminary test of approximately 700 interviews was conducted in order to refine interviewer training and procedures and adjust the questionnaires. But already the project had fallen behind schedule. Meanwhile, soon after the Carter administration came to power in January 1977, Commissioner Chapman was replaced by Leonel F. Castillo. In February, after several extensions of time, the contractor explained to Commissioner Castillo that the survey could not be completed with the $\$ 300,000$ that remained.

Congressional committees faced with the Carter plan of mass amnesty for illegal aliens began to fret. Where was Reyes? Where was the data? Congressman Sam B. Hall of the House Subcommittee on Immigration told Castillo at the

38. Id.

39. Id. at 2-3; Immigration and Naturalization Service, U.S. Dep't of Justice, Residential Survey: Conduct a Residential Survey to Estimate the Illegal Alien Population in the Twelve Most Populous States and to Obtain and Analyze Characteristics and Impact Data (Aug. 2, 1976) (memorandum).

40. Telephone interview with Ralph Thomas, Consultant to U.S. Immigration and Naturalization Service (Oct. 6, 1981).

41. Report of the Comptroller General, supro note 37, at 2; Telephone Interview with Robert Anderson, Office of Planning and Evaluation, INS (Nov. 13, 1981). 
March 1978 hearings: "I think I can see that he's going to come in and ask for additional funds."

"He already has," said Mr. Castillo. The figure under discussion was another $\$ 1,000,000.42$

Commissioner Castillo ordered the survey reduced to 10,000 interviews and extended the delivery date to October 9, 1978, allowing a total of twenty-five months. Finally, in June 1978, regular interviews got underway, but a month later the money ran out. Reyes wanted $\$ 130,000$ to complete at least a large sampling. Castillo told a reporter: "I decided that these cost overruns have a way of just running out of sight. So I felt it was simply time to cut bait and take what we had."43 As it turned out, Mr. Castillo had no fish. Reyes, aggrieved, refused to hand over the incomplete data. According to a reporter, he refused to discuss a court action that would force him to turn over the data and turn back some of the money. "Anything I've got to say would be twisted around to make me look like a jerk."44

What went wrong? The Government Accounting Office which investigates how public money is spent or misspent, usually after the fact, found that the original size, methodology, and timeframe of the Reyes Project were faulty, and that additional, awkward delays were caused by the inexperience of all groups involved. For example, a several month delay occurred while the INS tried to recruit cooperation from other government agencies. In addition, there was the surprising timidity of INS legal counsel who, after the contract had been signed, found themselves uncertain whether under the Privacy Act of 1974 information gathered from annual alien address reports could be used to identify areas for the Reyes study where legal and illegal aliens might cluster. ${ }^{45}$ Furthermore, INS personnel new to this type of research pestered Reyes Associates with requests for changes in survey design and questionnaire content, and both parties quarreled over contractual definitions. All the while, the contractor had to pay his inactive teams.

Presently, Mr. Reyes sits on top of whatever information his associates accumulated. No outsider has ever seen it. His legal stance is as formidable as that of the U.S. Census Bureau, as shown below in section VIII-C. He holds in trust confidential raw data and client information that conceivably could be abused by public officials or immigration officers. To say the least, Reyes Associates would want additional funding, possibly $\$ 150,000$ or more, to cover the cost of processing the unseen data, and to prepare an interpretative profile and final report. ${ }^{46}$

42. Dickey, SI Million U.S. Study Yields Dubious Resulss, The Washington Post, Dec. 10, 1978, at 1A, col. 5 .

43. Id.

44. Id.

45. Report of the Comptroller General, supra note 37, at 6; Telephone interview with William Joyce, Office of Planning and Evaluation, INS (Oct. 6, 1981).

46. Immigration and Naturalization Service: Hearings Before the Subcomm. on Immigration, Refugees and International Law of the Senate Comm. on the Judiciary, 96th Cong., Ist Sess. 145-50 (1979); Interview with Joseph A. Reyes, Immigration Consultant, Washington, D.C. (Aug. 23, 1981); Telephone interview with Steve Schroffel, Statistics Division, INS (Oct. 5, 1981). 


\section{Analytical-Residual Estimates of Illegal Aliens}

As the decade of the 1970's progressed and illegal aliens became a growing public policy concern, demographers, academicians, and statisticians, fascinated by the riddle of numbers, made some notable efforts to calculate the size of the illegal alien population using various analytical techniques. A few representative examples follow.

In 1974, Howard Goldberg, a graduate student at Georgetown University, did a seminar paper in demography interesting for its use of the "classic techniques" of the residual method for estimating a migrant population. He compared census data from Mexico and the United States for the years 1960 and 1970; then using survival rates and fertility rates for a ten-year period he calculated the expected population increase of Mexico had there been no out-migration. The actual 1970 Mexican census count was subtracted from the expected census count to reach a residual estimate of $1,860,000$ emigrants during that decade. Then subtracting the enumerated increase of Mexicans in the United States from 1960 to $1970(260,000$ according to the U.S. Census count), Goldberg reached a rough estimate of $1,600,000$ Mexican emigrants who had entered the United States illegally in the 1960 's and were still alive in $1970 .{ }^{47}$ For comparative purposes, the number of Mexican immigrants legally admitted into the United States during that same decade was 443,301.48 The Goldberg residual method employed a number of questionable assumptions, perhaps the most important of which was the assumption that the Mexican census omission rates in 1960 and 1970 remained relatively the same. ${ }^{49}$

In 1979, demographer David M. Heer, in another noteworthy example of the use of residual techniques, sought to approximate the net annual inflow of deportable Mexican nationals. He examined the increase in the Mexican-origin population in the United States, according to averages taken from the Census Bureau's annual Current Population Survey (CPS) for the years 1970 through 1975. Heer then calculated the natural increase in the Mexican-origin population allowing for births and deaths over a five-year period, and added the known amount of annual legal immigration, but allowed also for an assumed return rate to Mexico. In this way he reached the expected increase in the Mexican-origin population, which was then subtracted from the annual CPS survey estimates to leave residual estimates. Heer found that from 1970 to 1975 , illegal net immigration from Mexico ranged from 80,000 to 242,000 per year, and this added up to 400,000 to $1,200,000$ for the whole five-year period. ${ }^{50}$ Other demographers raise a number of questions

47. H. Goldberg, Estimates of Emigration from Mexico and Illegal Entry into the United States, 1960-1970, by the Residual Method 2, 5-6, 11, 13-14 (1974) (unpublished paper available from the Georgetown University Center for Population Research, Washington, D.C.).

48. Immigration and Naturalization Service, U.S. Dep't of Justice, Annual Report 64 (1970).

49. See Siegel, supra note 17, at 19-20; M. García y Griego \& C. Zazueta, Approaches to the Estimation of Deportable Mexicans in the United States: Conjectures or Empirical MeaSUREMENT? 18-20, 26-30, 47-50 (1980) [hereinafter cited as APPROACHES].

50. See Heer, What Is the Annual Net Flow of Undocumented Mexican Immigrants to the United States?, 16 
about Heer's assumptions and methodology, pointing out that the annual CPS sample surveys "move in an irregular fashion because of sampling and response errors." 51

An innovative attempt to compute the size of the illegal alien population in certain regions using residual techniques was presented in 1979 by $\mathrm{J}$. Gregory Robinson, ${ }^{52}$ who compared death rates for white males, age twenty to forty, in the period 1960 to 1975 for five states in the Southwest and five in the Northeast, where reportedly there were the largest concentrations of illegal residents. One should note here that for Census purposes, Mexicans and nearly all other immigrants fall into the white population category.

Robinson, a Census Bureau demographer, assumed that relatively few illegals showed up in Census counts of 1960 or 1970, or in the CPS of 1975, but that death statistics included most illegal residents in the ten-state area, and, moreover, that their death rates were similar to the general population. He reasoned that regions having a heavy concentration of illegal residents would naturally have death rates exceeding those of the general population. Indeed, his analysis of the data did show such higher rates; it also suggested that for 1975, the illegal population of white males, age twenty to forty-four, could range anywhere from 600,000 to $4,700,000.53$

Some of Robinson's assumptions have been found to be shaky by a subsequent Census Bureau study. ${ }^{54}$ Also, the observation has been made that Robinson was actually trying to measure a proportion of the total population missed by the Census. But that proportion could conceivably include, besides deportable aliens, other groups, such as visitors or Puerto Ricans, commonly missed by the Census. ${ }^{55}$ In any case, Robinson's range of estimates, like those of Heer, seem so wide that they would be of little practical use in public policy decisions about immigration.

In 1978, Clarise Lancaster and Frederick Scheuren of the U.S. Social Security Administration (SSA), using a sophisticated "multiple systems approach" and a combination of empirical and analytical techniques, estimated the total number of all illegal residents in the United States in 1973. They matched relatively small samples of IRS individual income tax returns, Social Security contributions, and beneficiary data for age groups eighteen to forty-four, with the CPS of March 1973. Assuming that IRS and SSA data included resident aliens, the authors compared that data with the CPS estimate which they assumed did not include an appreciable number of illegal residents. The difference amounts to an estimated stock population of 3,900,000 illegal residents aged eighteen to forty-four but with

Demography 417 (1979). This is a condensed version of a paper prepared by Heer, a demographer associated with the Population Research Laboratory, University of Southern California, for the Employment and Training Administration, U.S. Dep't of Labor.

51. Siegel, supra note 17 , at 22-24.

52. See Robinson, Estimating the Size of the Illegal Alien Population in the United States by the Comparative Trend Analysis of Age-Specific Death Rates, 17 DEMOGRAPHY 159, $159-76$ (1980).

53. Id. at $160-61,163,168-72$.

54. Siegel, supra note 17 , at $22-23$.

55. APPROACHES, supra note 49, at 18-19. 
a possible low of $2,900,000$ and a possible high of $5,700,000 .^{56}$

This study has been faulted on a number of points. For example, employment data for many illegal aliens paid in cash are lacking. Also, it is possible that many deportable aliens do, indeed, file income tax returns, and that many have SSA payments automatically deducted from paychecks, yet many of these could be Mexican and other seasonal workers who reside in the home country in the offseason. ${ }^{57}$

Nevertheless, the range of estimates offered by Lancaster and Scheuren seem quite plausible to immigration experts. Moreover, the "multiple systems approach" represents the first serious attempt by employees of a federal agency to apply a record-keeping methodology to the numbers game. Unfortunately, federal agencies have so far made little use of such techniques in estimating the number of illegal alien residents in the United States.

In the fall of 1981, Census Bureau demographer Robert Warren used two analytic methods to yield similar residual estimates of illegal aliens who entered in the period July 1970 to November 1979. In one study, Warren used estimates of the foreign-born population that entered the United States legally in that period based on INS data on legal immigrants, refugees, and foreign students, with allowances being made for emigration and mortality. The resulting figure of $3,474,000$ was then subtracted from the November 1979 CPS estimate of $4,612,000$ for the foreign-born population that entered in the period, leaving a difference of $1,138,000$. This latter figure would represent counted illegal aliens who entered in that same period, as. shown in table 8.

Warren's other residual technique used data on the number of aliens registering with the INS in January 1980 with an estimate of the completeness of the registration on form $\mathrm{I}-53$, which reports an entry date. The resulting estimate of $2,970,000$ registered aliens was then compared, with adjustments, to the November 1979 CPS estimate of $4,222,000$. The difference of $1,252,000$ is assumed to represent illegal aliens from all countries who entered the United States in the period 1970-1979 and who were counted by the CPS. The same techniques indicated that 734,000 of the counted illegal aliens came from Mexico, 240,000 in the period 1970 to 1974 , and 494,000 in the period 1975 to 1979 . Although one must allow for legals and illegals moving seasonally back and forth over the Mexican border, Warren's data seem to confirm a growing trend in illegal immigration. ${ }^{58}$

A study by University of Texas demographers, Frank D. Bean, Allan G. King, and others, with the special assistance of Jeffrey S. Passel of the U.S. Census

56. Lancaster \& Scheuren, Counting the Uncountable Illegals: Some Initial Statistical Speculation Employing Capture-Recapture Techniques, 1977 PROC. OF THE SOC. STAT. SEC., PART I 530-35 (1978) (proceedings of American Statistical Association. The authors were then with the Social Security Administration, U.S. Department of Health, Education and Welfare.).

57. ApproAches, supra note 49, at 14-16; see also Sehgal \& Vialet, Documenting the Undocumented: Data, Like Aliens, Are Elusive, U.S. Dep't LAB. MonThly LAB. Rev., Oct. 1980, at 18, 18-21.

58. R. Warren, Estimates of the Size of the Illegal Alien Population in the United States Table 3 (Nov. 12-13, 1981) (an unpublished paper presented to the Census Advisory Committee Meeting of the American Statistical Association in Washington, D.C.). 
TABLE 8

\begin{tabular}{|c|c|c|}
\hline \multicolumn{3}{|c|}{$\begin{array}{c}\text { Census Estimates of the Illegal Foreign-Born Population } \\
\text { THAT Entered the United States Between } 1970 \text { AND } \\
\text { November, } 1979\end{array}$} \\
\hline (1) & $4,089,000$ & $\begin{array}{l}\text { Immigrants and refugees } \\
\text { (INS Annual Reports, 1970-1979, and unpublished data for } \\
\text { refugees) }\end{array}$ \\
\hline (2) & 140,000 & $\begin{array}{l}\text { Nonimmigrant foreign students } \\
\text { (INS Alien Registration data, January 1979) }\end{array}$ \\
\hline (3) & 61,000 & $\begin{array}{l}\text { Deaths } \\
\text { (Estimates from U.S. life tables) }\end{array}$ \\
\hline (4) & 694,000 & $\begin{array}{l}\text { Emigration of } 1970-1979 \text { immigrants } \\
\text { (Assumes } 1960-1970 \text { Cohort emigration rate, DEMOGRAPHY, } \\
\text { Feb. 1980, at } 77 \text { ) }\end{array}$ \\
\hline (5) & $3,484,000$ & $\begin{array}{l}\text { Estimates of foreign-born population } \\
\text { (Controlléd to January } 1980 \text { totals, adjusted by } 9.2 \% \text { for } \\
\text { underreporting) }\end{array}$ \\
\hline (6) & $4,612,000$ & $\begin{array}{l}\text { November } 1979 \text { Current Population Survey, CPS } \\
\text { (Adjusted to be consistent with corrected independent controls } \\
\text { and for overreporting of naturalization of foreign born } \\
\text { population) }\end{array}$ \\
\hline \multicolumn{3}{|r|}{ Poputanis } \\
\hline (7) & $1,138,000$ & $\begin{array}{l}\text { Difference between (5) and (6) } \\
\text { (Presumably census-counted illegal aliens who entered 1970- } \\
\text { 1979) }\end{array}$ \\
\hline
\end{tabular}

Source: R. Warren, Estimates of the Size of the Illegal Alien Population in the United States 9 (Nov. 12-13, 1981) (adapted from Table 2) (presented to the Census Advisory Committee Meeting of the American Statistical Association, Bureau of the Census).

Bureau, is apparently the first serious attempt to estimate by analytical methods the size of the "undocumented" population for a given state. The study came in response to a request by Governor William P. Clements, Jr., and other state officials for estimates of illegal Mexican migrants in Texas in order to support arguments before the Supreme Court that untold numbers of undocumented migrant children should not be entitled to a free public education at local expense. ${ }^{59}$ Also, deeply concerned about sweeping amnesty proposals in Congress, Texas officials wanted more information about the possible size of the undocumented Mexican population.

Primary sources used by the authors were 1970 and 1980 census information on the Spanish surname population of Texas, residential information on persons of Mexican foreign stock, and annual alien registration data for legal Mexican immigrants, together with data on the characteristics of apprehended persons and on Mexican immigrants whose intended state of residence was Texas. Significantly, an alternative set of estimates was derived from Mexican census information for 1970 and 1980; and from Mexico's CENIET residential surveys, discussed in section VII-C.

59. Plyler v. Doe, 102 S. Ct. 2382 (1982). 
The use of Mexican census data involved an analysis of sex ratios for the 1970 and 1980 enumerations and cohort survival ratios for age groups, particularly the age group fifteen to thirty-nine years. This methodology rests on the premise that-in Texas at least-the migrant flux over a porous border is mainly a phenomenon associated with young males and that Mexican census data should therefore show a relative absence of males. ${ }^{60}$

Using a sophisticated combination of analytical-residual techniques that, among other things, compared the expected growth of the Mexican-origin population in Texas with the reported growth during a decennial period, the authors reached a range of estimates for the undocumented Mexican migrant population in 1980. The extremes ran from 568,100 to 918,000 , with an average midpoint of $763,800 .{ }^{61}$ The average figure might easily be too low, not only because of census undercounts, but because of the fraudulent use of "Tex-Mex" birth certificates for several generations.

In a follow-up study, also directed toward the Governor's Task Force on Illegal Aliens, Bean and King attempted to gauge the size of the undocumented Mexican population on a national scale. Making the same assumptions and using similar sources and methodology, including the lower proportion of males in Mexican census data for 1970 and 1980 , the authors concluded that the number of illegal Mexican migrants in the United States in 1980 ranged from $1,800,000$ to $4,200,000$, with an average estimate of $2,900,000 .^{52}$

With respect to the carefully calculated estimates of Bean and King, a Mexican observer might note that one problem with the sex-based ratios as found in Mexican census data is that the lower proportion of males may be due as much to the migration of rural unemployed men and boys to Mexican cities as to their migration to the United States. Mexican cities swarm with transient males, and it is probable that the Mexican census seriously undercounts this vagrant population.

Moreover, estimates based on sex-based ratios do not seem to take fully into account the fact that family members usually follow an undocumented worker who decides to settle in the United States, and that he or she usually does not reveal family facts. What is clear is that uncounted family members, in cumulative fashion, are generating a growing concern about social costs. ${ }^{63}$

In general, the analytical-residual techniques used by Goldberg, Heer, Robinson, Lancaster, Scheuren, Warren, Bean, King, Passel, and others have brought a much-needed scientific methodology to the numbers game. They have also served to discredit exaggerated estimates of deportable populations by emphasizing that the most important measure is not the gross flow but the net flow and

60. F. Bean \& A. King, Estimates of the Number of Illegal Migrants in the State of Texas 26-31 (Mar. 15, 1982) (a report prepared, with the assistance of $\mathbf{R}$. Benford, L. Perkins, and others associated with the Population Research Center of the University of Texas, for the Governor's Task Force on Illegal Aliens, Governor's Office of Budget and Planning).

61. Id. at $36-37$.

62. F. Bean \& A. King, A Sex Ratio-Based Estimate of the Number of Illegal Migrants of Mexican Origin in the United States 2, 10, 17 (Summer 1982) (available from The Center for Population Research, University of Texas at Austin).

63. Immigrants-and Immigrants: Perspectives on Mexican Labor Migration to the United States 291-93 (A. Corwin ed. 1978). 
the cumulative stock. ${ }^{64}$

On the other hand, as the GAO has emphasized to immigration reform leaders in Congress, no one has yet developed a satisfactory methodology for counting diverse groups of people who do not want to be counted. So far, the most that the GAO can propose is "a multi-indicator method" in which it hopes possible errors would counterbalance each other. ${ }^{65}$

\section{V \\ Speculative Estimates of Illegal Aliens}

The subject of "How many illegal aliens?" naturally invites speculative estimates. In their simplest form these are impressionistic guesses. More advanced are the speculative methodologies or techniques which may employ a combination of fragmentary data, reasonable assumptions, informed guesses from experienced people, simple arithmetic, and logic, and which may yield estimates of a "shadow population" sometimes more in accord with common sense and the observer's eye than those produced by the more scientific methodologies. Two examples of speculative estimates are the Lesko survey and the immigration district survey which were described in section III.

Another representative example of speculative estimates is provided by labor economist Walter F. Fogel at the University of California, Los Angeles, in a study of Mexican illegal workers published in 1978.66 Fogel started with a 1975 statement made by Commissioner Chapman to the effect that immigration records failed to account for the departure of $10 \%$ of the more than $6,000,000$ annual foreign visitors, and that an estimated $5 \%$ had actually remained in the United States. Fogel, who presumably used INS data, apparently assumed that about $30,000,000$ nonimmigrant visitors were admitted to the U.S. interior in the period 1965-1974. Chapman's estimate thus could mean that during a ten-year period 1,500,000 nonimmigrants, presumably Mexican nationals, remained illegally in the United States. 67

Fogel gave a second example of speculative approaches. According to experienced immigration officers and a 1973 California agricultural study, the INS has only a one-in-five chance of apprehending an illegal entrant who has been in the country for a month or more. In 1974 about 200,000 illegals, presumably Mexicans, were so reported. One might then assume that another 800,000 went undetected. Allowing "rather arbitrarily" that half of this number return voluntarily to Mexico, the net addition would be 400,000 for 1974 . Using INS apprehension data, Fogel estimated that possibly 4,000,000 Mexicans entered illegally in the years 1965 to 1974 . If half returned voluntarily this would leave a cumulative stock figure of 2,000,000 for that period. If one added 200,000 for the current 1974 net flow, and 1,500,000 nonimmigrants, the illegal alien population, presumably

64. Heer, supra note 50 .

65. U.S. General Accounting Office, Problems and Options in Estimating the Size of the Illegal Alien Population i-iii, 19-23 (1982).

66. W. FOGEL, supra note 12, at 23-25.

67. Id. 
Mexican, at the end of a ten-year period becomes 3,700,000.68 Fogel's main point in this little exercise was to show how simple it is to make speculative estimates with any available figure and some convenient assumptions. The limitations of such speculative techniques have been discussed at length by demographers Manuel García y Griego and Carlos H. Zazueta. ${ }^{69}$

In a more complex example of speculative techniques, Edwin P. Reubens, an economist, at the City College of New York, sought to measure the net annual inflow of illegal workers. ${ }^{70} \mathrm{He}$ started with an annual apprehension figure of $1,000,000$ a year (as in fiscal 1977, 1978, and 1979, according to INS figures) and used assumptions about "got-away" ratios and return rates of deportable aliens obtained from experienced immigration agents in five immigration districts facing the largest inflows of illegals.

Discounting "repeaters," Reubens estimated that 600,000 individual illegals were apprehended in a year such as 1979. This latter figure was then doubled to represent the estimated number of illegals who successfully avoided apprehension. Another informed assumption was that most of the 1,200,000 illegal entrants were young, able-bodied adults, and, therefore, it was estimated that $80 \%$ or 960,000 , participated in the American labor market. From the latter figure, $40 \%$ was deducted to account for short stays and voluntary returns, leaving 600,000 as the net annual inflow of all illegal foreign workers in 1979. Of the aforementioned number, 450,000 or $75 \%$ were estimated to be Mexicans. ${ }^{71}$

In a matter of related interest, Professor Reubens estimated the cumulative stock of foreign workers, legal and illegal, for the eight years 1972-1979. For legal permanent alien workers, an annual figure of 180,000 net inflow was used; the accumulation came to $1,440,000$. This inflow figure was based on INS admissions of legal resident aliens at approximately 400,000 per year, with a $60 \%$ labor-participation rate $^{72}$ and further reduced by a $25 \%$ return rate (based on intercensal data), yielding an annual figure of 180,000.

For refugees, who were relatively few from 1973 to 1979, an accumulation of 120,000 workers was adopted. The temporary foreign workers, mostly admitted as seasonal workers, were treated as revolving stock, and thus contributed 100,000 workers. "Finally, for the illegals_whose numbers have been rising strongly during the 1970's, so far as the entry trend may be measured by the reported apprehensions - we adopt an average of 480,000 annual net inflow, and multiply by eight years, to yield an accumulation of $3,840,000$ illegal workers." 73 The sum

\section{Id.}

69. APPROACHES, supra note 49 , at $47-50$.

70. See Reubens, Immigration Problems, Limited-Visa Programs and Other Options, in U.S. IMMIGRATION Policy and the National Interest: Appendix F to Staff Report of the Select Comm'n on Immigration and Refugee Policy 89, 91-139 (1980) (Supplement to SCIRP Final Report) [hereinafter cited as Appendix F to SCIRP FinAl REPORT]; Aliens, Jobs and Immigration Policy, PUB. INTER EST, Spring 1978, at 113, 116-17.

71. See Reubens, supra note 70; Aliens, Jobs and Immigration Policy, supra note 70.

72. Rate derived from U.S. DOMEstic Council Comm. ON Illegal Aliens [Executive Office of THE PRESIDENT], supra note 36.

73. Appendix E to SCIRP Final REPORT, supra note 2, at 133-34. 
of all the foregoing classes amounted to a net accumulated stock of 5,500,000 foreign workers during the period 1972-1979.

Such estimates in the aggregate seem realistic to experienced immigration officers and more acceptable than the results from most analytic-residual studies, but since the methodology depends here and there on "educated guesswork," it would be naturally difficult to prove or disprove the accuracy of Reubens' figures. Also, it is possible that he may have overestimated somewhat the net annual inflow of Mexican illegal workers by not adjusting enough for INS concentration of enforcement efforts in the states bordering on Mexico (90\% of the Border Patrol is there) resulting in high apprehension rates for Mexican aliens, including "repeaters," and low arrest rates for other nationalities. ${ }^{74}$

In fact, during the past several years about $87 \%$ to $90 \%$ of all INS apprehensions have been Mexican nationals. ${ }^{75}$ (Annual apprehension figures are included in appendix A.) However, experienced immigration employees believe that perhaps $40 \%$ to $50 \%$ of the present net inflow of illegal alien workers and family members are non-Mexican, mostly arriving as superficially inspected tourists and visitors at international airports. ${ }^{76}$ Here, two complementary factors are U.S. consulates overseas that hurriedly issue visas and the shortage of trained immigration inspectors at ports of entry. (Shortages of immigration and consular personnel are reflected in appendices $B$ and $C$.)

What has been said about Reubens' flow estimates could partially apply to those of Milton D. Morris and Albert Mayio, who estimated the undocumented flow from Mexico for the year 1978 as running between 1,075,000 and 1,735,000.77 This rough approximation, which assumes a heavy return flow of seasonal workers, was derived from INS apprehension data, questionable INS estimates of "gotaway" ratios, and the percentage of fraudulent entrants based on the INS 1976 study, and CENIET flow information as shown in section VII-C.

Also, Morris and Mayio used flow estimates from Lesko Associates to estimate the stock of illegal immigrant populations. After assuming a base figure of about $1,000,000$ illegal Mexican residents in the United States in 1970, they then added the estimated net flow over the ensuing eight years to reach an estimated illegal Mexican population of 2,400,000 in 1977. By similar speculative methods the authors estimated the total illegal alien population to run from $4,300,000$ to $6,200,000 . .^{78}$

In the fall of 1978 President Carter appointed the Select Commission on Immigration and Refugee Policy (SCIRP) under the chairmanship of Father Theodore Hesburgh, President of Notre Dame University. ${ }^{79}$ In 1980 SCIRP, influenced by

74. APPROACHES, supta note 49, at 47-50.

75. Immigration and Naturalization Service, U.S. Dep't of Justice, AnNual Report Table 30 (1970); see also id. at app. A.

76. Television interview of Kenneth T. Blaylock, American Federation of Government Employees, on NBC Meet the Press (Sept. 6, 1981).

77. M. Morris \& A. Mayio, Foreign Policy Aspects of Illegal Immigration A-3-7 to A-3-11 (1980) (prepared for the U.S. Dep't of Labor).

78. Id. at 3-57 to $3-60$.

79. The sixteen-member commission, which included distinguished congressmen, senators, cabinet 
the Reyes fiasco, requested Census Bureau demographers (but not the Census Bureau per se) to give their best estimate of the number of illegal resident aliens in the United States. ${ }^{80}$ This speculative study, authored by Jacob S. Siegel, Jeffrey S. Passel, and J. Gregory Robinson, was entitled Preliminary Review of Existing Studies of the Number of Illegal Residents in the United States. ${ }^{81}$ The authors did no empirical research of their own, but rather a careful evaluation and critique of selected studies conducted during the 1970's that had made a significant or plausible effort to measure the size of the illegal alien population or the net inflow, as seen in appendix D.

In conclusion, the three demographers offered the following as "cautious speculations":82

The total number of illegal residents in the United States for some recent year, such as 1978 , is almost certainly below 6.0 million, and may be substantially less, possibly only 3.5 to 5.0 million . . . .

The Mexican component of the illegally resident population is almost certainly less than 3.0 million, and may be substantially less, possibly only 1.5 to 2.5 million.

No estimate was made of the percentage of illegals that might have been in the U.S. labor force.

Having nothing more substantial to go on, most members of SCIRP accepted the foregoing estimates as a working hypothesis, but they had no clear sense of proportion between family dependents and workers. ${ }^{83}$ Consequently, such estimates, considered conservative by some immigration experts, helped shape some of the rather generous recommendations of SCIRP submitted to the President and

members, and persons representing ethnic minority and labor interests, was under the executive direction of Dr. Lawrence Fuchs of Brandeis University.

SCIRP, at work from October 1978 to March 1981, was mainly concerned with gathering testimony and policy recommendations with respect to: (1) the socioeconomic impact of immigrants, legal and illegal, and refugees; and (2) reform needs in immigration and refugee policies. This was mainly accomplished through twelve regional meetings held in such cities as New York, Chicago, Miami, Denver, Los Angeles, and San Antonio, and through invitations to specialists in immigration and immigrant labor to present an account of their research findings, their interpretations and their policy recommendations to SCIRP, the Carter Administration's standing Interagency Task Force on Immigration, the Department of Labor, or congressional hearings.

Among social scientists and professional researchers who contributed, one way or another, to the SCIRP, and whose research is relevant to the study of illegal immigration and "cheap labor," were the following: economists Vernon M. Briggs, Jr., Philip Martin, Barry Chiswick, Julian Simon, Edwin P. Reubens, and Sidney Weintraub; political scientist Wayne Cornelius; researchers David S. North and Guillermina Jasso; and demographers Leon F. Bouvier, Michael Teitelbaum, and Charles Keely.

80. The Select Commission was expected to carry out the most thorough study ever made of national immigration policy and the impact of immigration on American society and economy. It started out with some hope that the Reyes survey might still produce some acceptable results, but strangely, SCIRP did not insist on residential survey information about illegal aliens. See, supra text accompanying notes 35-46. A consideration here was that government agencies and commissions, feeling burned by the "Residential Survey," hardly dared to recommend spending money on another residential survey attempt. Consequently, SCIRP settled for a "speculative estimate" of the illegal alien population.

81. Reprinted in Appendix E to SCIRP FINAL REPORT, supra note 2, at 15-39.

82. Id. at 33 .

83. See Final Report of the Select Comm'n on Immigration and Refugee Policy: Joint Hearings Before the Subcomm. on Immigration and Refugee Policy of the Senate Judiciary Comm. and Subcomm. on Immigration, Refugees, and Intemational Law of the House Comm. on the Judiciary, 97th Cong., 1st Sess. 23-52 (1981) [hereinafter cited as Joint Hearings]. 
Congress on March 1, $1981 .^{84}$

In any case, conjectural estimates of illegals tend to run much higher than the $3,500,000$ to $6,000,000$ figure currently used by the Reagan administration and various legislators in formulating immigration reforms. The example below in table 9 of a higher conjectural estimate, based on some recent research by the author, might at least serve to suggest the need to break down a rather vague global estimate of illegal aliens into certain component parts.

TABLE 9

\section{Conjectural Estimates of Illegal Aliens Settled in the UNITED STATES IN $1981^{85}$}

\begin{tabular}{|c|c|c|}
\hline LOW & $\underline{\mathrm{HIGH}}$ & \\
\hline \multirow[t]{2}{*}{$5,400,000$} & $6,790,000$ & $\begin{array}{l}\text { MEXICAN. Mostly unskilled and semi-skilled workers, male } \\
\text { and female, who, because of border proximity, have on the } \\
\text { average possibly } 60 \% \text { to } 70 \% \text { family dependents in the } \\
\text { household, including many U.S. born children. }\end{array}$ \\
\hline & & $\begin{array}{l}\text { Rough breakdown: California, } 2.5-3.0 \text { million; Texas } 2.0-2.5 \\
\text { million; Illinois, } 250,000-350,000 \text {; Colorado, } 150,000-200,000 ; \\
\text { Arizona, } 90,000-100,000 \text {; New Mexico, } 60,000-90,000 \text {; other } \\
\text { states, } 400,000-500,000 \text {. }\end{array}$ \\
\hline \multirow[t]{2}{*}{400,000} & 530,000 & $\begin{array}{l}\text { CARIBBEAN. Mainly unskilled workers and family dependents } \\
\text { who commonly live near black and Puerto Rican populations, } \\
\text { as in New York City, Newark, Miami, and Washington, D.C. } \\
\text { Also includes many middle- and upper-class expatriate families, } \\
\text { many with professional training. }\end{array}$ \\
\hline & & $\begin{array}{l}\text { Rough breakdown: Dominicans, } 140,000 \text { to } 180,000 \text {; Haitians, } \\
150,000-200,000 ; \text { Jamaicans, } 80,000-100,000 \text {; plus } 30,000-50,000 \\
\text { Trinidadians, Tobagans, Barbadians, and others, some of them } \\
\text { in the U.S. Virgin Islands and Puerto Rico. }\end{array}$ \\
\hline \multirow[t]{2}{*}{390,000} & 500,000 & $\begin{array}{l}\text { CENTRAL AMERICAN. Mostly in Hispanic areas of Los } \\
\text { Angeles, San Francisco, New York, Chicago, Miami, Houston, } \\
\text { and Washington, D.C., employed as common labor and } \\
\text { domestics. But includes many student overstays, and tens of } \\
\text { thousands of quasi-political and "economic" refugees from all } \\
\text { social classes, mainly Salvadorans and Nicaraguans, of the latter } \\
\text { several thousand have been granted asylum. }\end{array}$ \\
\hline & & $\begin{array}{l}\text { Rough breadown: †Salvadorans, } 200,000-230,000 \text {; Guatemalans, } \\
70,000-110,000 \text {; Panamanians, } 60,000-70,000 \text {; Nicaraguans, } \\
40,000-50,000 \text {; other, } 20,000-30,000 \text {. }\end{array}$ \\
\hline
\end{tabular}

$\dagger$ Early 1982 estimates of undocumented Salvardoran "refugees" run as high as 400,000 .

84. SCIRP FINAL REPORT, supta note 2.

85. Information for the estimates was derived from the following sources: (1) Rough estimates and conjectures from district immigration officers, police officials, educators, and Hispanic and other ethnic leaders, gathered during tour by author of 24 district immigration offices and substations and seven border patrol sectors in midwestern and southwestern states, March 1 to April 10, 1981, and May 1 to June 15, 1981, and Washington, D.C., June 18 to June 23, 1981; (2) Newspaper articles on 1980 Census topics and alleged undercounts in such cities as New York, Detroit, Chicago, Houston, and San Francisco; (3) Various studies and congressional hearings on illegal aliens; (4) Mexican press coverage, principally from Excelsior, 
$270,000380,000$ SOUTH AMERICAN. Mostly in metropolitan cities like New York, Miami, San Francisco, Los Angeles, Miami, Houston, Chicago, and Washington, D.C. Includes a mix of overstay students and visitors, professionals, expatriates, drug traffickers, as from Colombia, and common laborers.

Rough breakdown: Colombians, 100,000-120,000, Argentinians, 40,000-60,000, Ecuadorans, 30,000-50,000; Peruvians, 20,000-

30,000 ; other, $80,000-100,000$.

440,000 540,000 ASIAN. Principally in "China towns," as in Los Angeles, San Francisco Bay area, or New York City. Includes many overstay students and trainees, as well as numerous relatives who labor in small family-run shops and restaurants or in nearby garment "sweat shops."

Rough breakdown: Chinese-Taiwanese, 300,000-350,000; Koreans, 40,000-60,000; Southeast Asians, 80,000-100,000; Japanese, 20,000-30,000.

$250,000300,000$ FILIPINO. Mainly in California and Hawaii as unskilled and semiskilled labor, but also includes many overstay students, visitors, trainee professionals, relatives, and expatriates of all social classes.

Mexico City, on Mexican groups in the United States; (5) Telephone calls to consular personnel and to immigrant-aid societies.

Of the illegal aliens currently settled in the United States, possibly $2,000,000$ to $3,000,000$ would be employed full-time, year-round. Many help produce and distribute agricultural and industrial goods, and many perform essential services, as in hospitals and nursing homes. But according to immigration officers, most illegals seem to perform work of marginal economic value, as in taxi-driving, domestic service, car washes, hotels, restaurants, laundries, janitorial service, or in the secondary labor market as assembly-line workers or garment workers. Teenagers or machines could do much of the foregoing labor, or it could be done in satellite plants in Hong Kong, or in Mexico's border industrial zone.

In addition, a growing number of illegals are employed part-time or full-time in mini-retail businesses, such as ethnocentric shops and food services run by immigrant friends or relatives within rapidly growing immigrant colonies. Here also recently arrived women and teenagers are often employed as domestic servants for other immigrants. The INS, laboring under manpower and court restrictions, has virtually no control over employment patterns in immigrant colonies.

In estimating the total size of the illegal work force one should allow for part-time workers. Also, one should add perennial seasonal workers, particularly Mexican transborder migrants who may number anywhere from 400,000 to $1,000,000$, depending on the season. Furthermore, an estimated 250,000 to 300,000 Mexico border-town dwellers cross almost daily as shoppers and visitors to work illegally in American border communities primarily in low-paying service jobs.

If the latter two Mexican-origin groups were counted as part of the illegal alien population in the United States in a given season the total conjectural estimate would run in a higher range, from $8,600,000$ to $11,000,000$. Not included in that range are a large number of older illegal immigrants and overstay visitors, mostly from Western Europe and Canada, who have become integrated in the mainstream of American society, but who never bothered to legalize their status, even though they may have raised a family in the United States.

From the viewpoint of subcultural and exploitation problems, the resident illegal alien population, perhaps $40 \%$ to $50 \%$ of it counted in the 1980 census, consists overwhelmingly of Third World immigrants who have settled in the United States since 1960, mainly in introverted subcultures, where, according to immigration officers, there is relatively little interest in naturalization. In Third World cultures there is a strongly felt obligation to bring in members of the extended family, with or without visas, so that the number of dependents grows. Although many Third World illegals are single, or have not yet brought in family members, the ratio of family dependents to each full-time worker, male or female, is probably near two to one on the average, and in Mexican households probably three to one, and higher near the border. 
$320,000 \quad 350,000$ MIDDLE EASTERN AND EAST INDIAN. Many are overstay students, professionals, political exiles-relatives, with some common labor recruits, from such countries as Iran, Iraq, Jordan, India, and Pakistan.

$500,000600,000$ OTHER. Includes overstay students, professionals, businessmen, tourists, and relatives, maybe half from Canada, and most of the remainder from the British Isles and Europe, notably Greece, Italy, Portugal, and Slavic countries, where kinship obligations are strong, together with some Africans, former students mostly.

$7,970,000 \quad 9,990,000 \quad$ TOTAL

\section{VI}

Socioeconomic Profiles of Illegal Aliens

Congressional hearings on immigration bills starting in the early 1970's revealed, among other things, a woeful lack of firm economic and social data about illegal aliens. How many are in the American labor force and in what sectors? What immigrant nationalities are found in this or that sector? Do they displace American workers? What percentage of illegal workers receive unemployment compensation or social security benefits? How many use social assistance and health programs? How many have taxes deducted from paychecks?

\section{A. INS Profile Data}

The INS, during the term of Commissioner Chapman in 1973-1976, for the first time made a methodical effort to gather and provide data on patterns of illegal alien employment and wage levels. Table 10 is an example.

TABLE 10

Estimated Number of Employed Illegal Aliens in the WESTERN REgION BY CATEGORY OF EMPLOYMENT AND BY Wage SCALE Ranges Fiscal Year 1976

\begin{tabular}{lrrrrr}
\hline Category & $\$ 6.50$ & $\$ 4.50$ & $\$ 2.50$ & Less Than & \\
\hline Heavy Industry & 333 & 500 & 1,167 & \multicolumn{1}{c}{$\$ 2.49$} & \multicolumn{1}{c}{ Total } \\
Light Industry & 1,167 & 4,585 & 97,189 & 104,607 & 207,533 \\
Agriculture & 500 & 7,002 & 643,482 & 109,213 & 850,197 \\
Construction & 583 & 583 & 3,084 & 2,251 & 6,501 \\
Services & 583 & 1,167 & 13,670 & 24,672 & 40,092 \\
\hline \multicolumn{1}{c}{ TOTALS } & 3,166 & 13,837 & 758,592 & 331,076 & $1,106,671$ \\
\hline
\end{tabular}

Source: Robert J. Seitz, Public Information Director, INS, ciled in M. VILLALPONDO, A STUDY of the Socionconomic Impact of Illegal. Aliens on the County or San Diego 48, Table 6 (1977) (citing Rober J. Seitz, Public Information Director) (copies available from county). 
Under Commissioner Chapman the INS also provided speculative estimates on the number of illegal workers by regions. The following table, prepared mostly by investigative staffs in the district offices, is an example.

Since the departure of Chapman early in 1977, the INS has made little effort to measure or estimate either the size or the socioeconomic impact of illegal alien groups. Having committed itself to a human rights policy for disadvantaged people everywhere, and having appointed Mexican-American Leonel Castillo as Commissioner of Immigration, the Carter administration was hypersensitive to complaints by Hispanic leaders, civil libertarians, and affirmative action employees that immigration data and speculative estimates on alien jobholders were being used to "scapegoat" Hispanic minorities and to hustle the American Government into taking deportation measures against the "undocumented worker" class. ${ }^{86}$ However, the INS did continue to provide Congress with appre-

\section{TABLE 11}

Estimated Totals of All Employed Illegal Aliens by

IMMIGRATION REgIONS AND DISTRICTS, FISCAL 1976

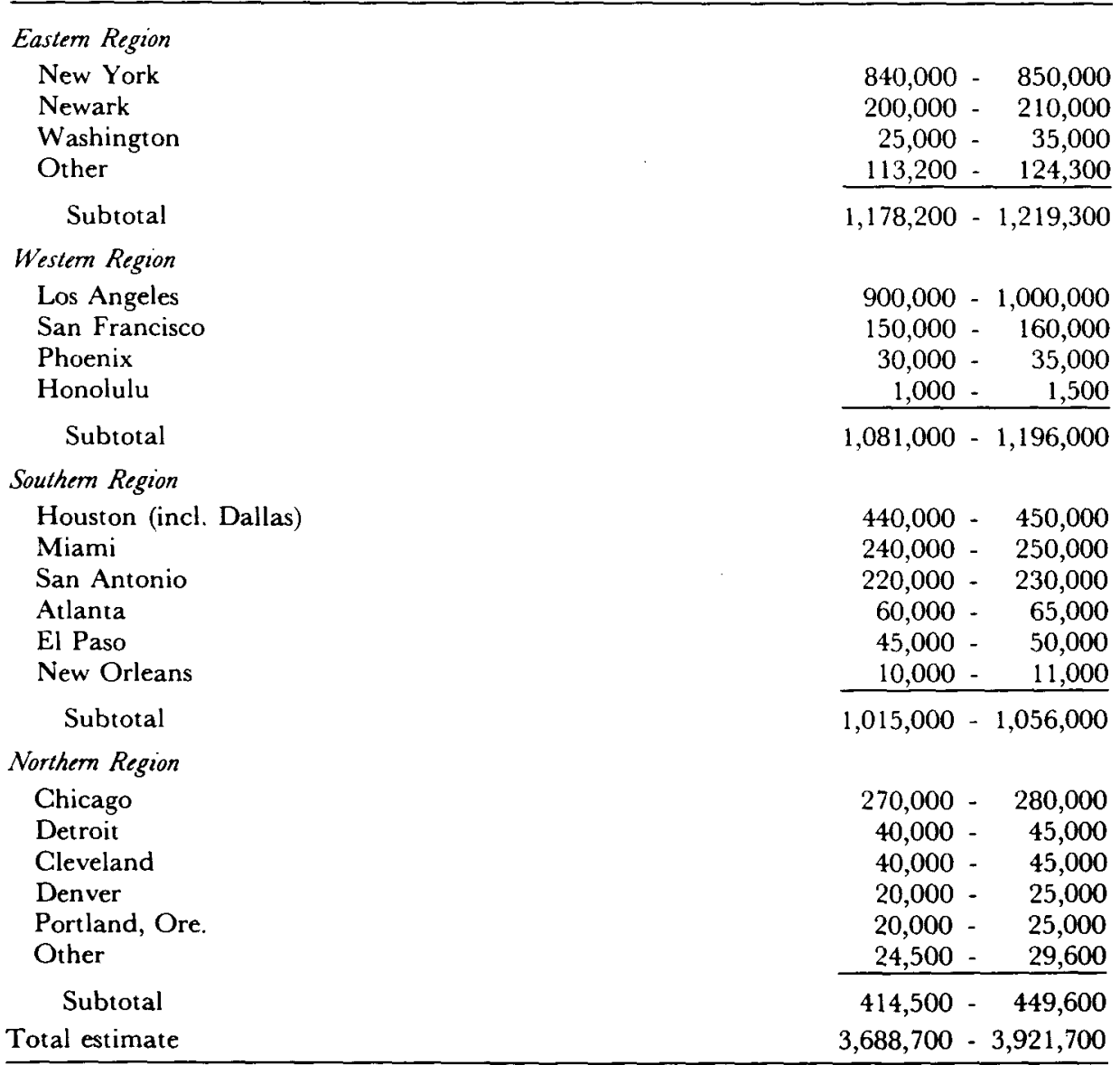

Source: Immigration 1976: Hearings on S. 3074 Before the Subcomm. on Immigration and Naturalization of the Senate Judiciary Comm., 94th Cong., 2d Sess. 39-41 (1976).

86. Corwin, A Human Rights Dilemma: Carter and "Undocumented" Mexicans, in IMmigrants-AND 
hension data indicating the distribution of illegal workers by industry and comparative wage levels.

\section{B. The North and Houstoun Study of 1976}

In January 1975, in the middle of the recession, the Ford administration set up a Domestic Council Committee on Illegal Aliens consisting of top officials and their aides from all major departments of the Federal Government under a coordinating arrangement with the Department of Justice and its Immigration Service. The Domestic Council task force initiated, through several federal agencies, factgathering studies to determine, if possible, the number of illegals and their real impact on the job market and the American economy, and the "dollar drain" to immigrant sending countries. Social costs were also to be investigated because local officials increasingly were seeking compensation from the Federal Government for health, welfare, and education services rendered to illegal immigrants and their families. ${ }^{87}$

The most important and influential of the studies initiated by the Domestic Council was that done in 1976 under contract to the Department of Labor by David S. North and Marion F. Houstoun. ${ }^{88}$ This study was the first methodical effort to establish the employment and wage patterns of deportable aliens, and to get at least some comparative information on non-Mexican illegals. The INS assisted with the project, in part because it was a logical extension of the study design sponsored by Commissioner Chapman, discussed above in section III.

In the spring of 1975 at nineteen different sites, including Los Angeles, San Francisco, Seattle, San Antonio, Miami, Chicago, Detroit, Washington, D.C., Newark, and New York City, researchers interviewed 793 illegals, of whom 481 were from Mexico, 237 from other Western Hemisphere countries, and 75 from Eastern Hemisphere countries. Some of them had not been apprehended.

From this sample a much needed socioeconomic profile of the illegal work force was obtained. The respondents' average stay in the United States was 2.5 years, their average age 28.5 years (compared to an American work force average of 35 ), and their average education 6.7 years, with Mexicans averaging 4.9 years. Although some had family dependents already in the host country, $88 \%$ of the Mexican respondents said they were supporting dependents in Mexico, sending home an average of $\$ 129$ per month out of an average monthly wage of $\$ 424 .{ }^{89}$

Immigrants: Perspectives on Mexican Labor Migration to the United States 320, 320-22, 325 , 335, 339 (A. Corwin ed. 1978).

87. See Corwin \& Fogel, supra note 24, at 281.

For an example of social-cost studies generated by the Domestic Council Committee on Illegal Aliens, see U.S. Comptroller General (GAO), Impact of Illegal aliens on Public Assistance ProGRAMS: TOO LITTLE IS KNOWN (1977).

For an example of fact-finding at the state level, see DeP'T of Justice, STATE of CaLifornia, Undocumented Aliens: A Califor nia Focus (1977).

88. D. North \& M. Houstoun, The Characteristics and Role Of Illegal Aliens in the U.S. LABOR MARKET: AN EXPLORATORY STUDY (1976) (prepared for the Employment and Training Administration, U.S. Dep't of Labor).

89. Id. at 80 , Table IV-5. 
Another significant finding was that hourly wages were lower for apprehended illegals, $\$ 2.71$ on the average, compared to $\$ 3.95$ for undetected illegals. Other hourly wage averages were: Eastern Hemisphere illegals, \$4.08; Western Hemisphere illegals, $\$ 3.04$; and Mexican illegals, $\$ 2.33$. Average hourly wages in agriculture, where many Mexicans were employed, were $\$ 2.01$ compared with $\$ 2.83$ for nonagricultural work. The further from the Mexican border one moved, the higher the average wages became: $\$ 3.18$ for the Midwest and Northwest, and $\$ 3.29$ for the east coast. At that time minimum wages in the United States ranged from $\$ 2.00$ to $\$ 2.50$. The declared occupation of informants in their home countries is indicated in the table below.

TABLE 12

OCCupational Distribution of Illegals InTERviewed

\begin{tabular}{lcccc}
\hline Illegals & $\begin{array}{c}\text { \% in White-collar } \\
\text { jobs }\end{array}$ & $\begin{array}{c}\% \text { in } \\
\text { Crafts }\end{array}$ & $\begin{array}{c}\text { \% Working as } \\
\text { Operatives }\end{array}$ & $\begin{array}{c}\% \text { in Service and } \\
\text { Laborers }\end{array}$ \\
\hline E.H. & 48 & 13 & 27 & $13(1.3 \%$ in agriwork $)$ \\
W.H. & 34 & 15 & 27 & $24(13 \%$ in agriwork $)$ \\
Mexican & 7 & 15 & 13 & 63 (50\% in agriwork) \\
\hline
\end{tabular}

Source: Employment and Training Administration, U.S. Dept. of Labor, Executive Summary of D. North \& M. Houston, The Characteristics and Role of Illegal aliens in THE U.S. LABOR MARKET (1976), (1976).

Except for operatives, skilled illegals, like many immigrant groups coming from a village craft economy, tend to lose occupational status on entering an industrialized economy. On the other hand, the least skilled, those from Mexico, exhibit some upward mobility, especially as operatives in factory work. ${ }^{90}$

TABLE 13

Economic Mobility of Mexican Illegals

\begin{tabular}{lcc}
\hline Mexican Illegals & \% in Mexico & \% in United States \\
\hline White-collar workers & 7 & 1.5 \\
Craft workers & 15 & 16.0 \\
Operatives & 13 & 24.0 \\
Service and Laborers & 65 & 58.0 \\
\hline Source: & Employment and Training Administration, U.S. Dep't of Labor, Executive Summary of \\
& D. NORTH \& M. HOUSTON, THE ChARACTERISTICS AND ROLE OF ILLEGAL ALIENS IN \\
&
\end{tabular}

North and Houstoun concluded from their sample of aliens from both hemispheres that most "illegals are taking jobs that no Americans want."91

C. Other Important Profile Studies

Other researchers raised similar doubts about the restrictionist concern that

90. See id. at 80-113, Table V-7; see also U.S. Comptroller General, supra note 87, ch. 5.

91. D. NORTH \& M. HOUSTOUN, supra note 88 , at $162-63$. 
illegal aliens were, all in all, a socioeconomic liability, or that most job slots opened by removing illegal aliens would be filled by jobless Americans, as Commissioner Chapman was wont to say. Aside from Bustamante, Cornelius, and the Mexican side of the research discussed in section VII, researchers on the American side, including Manuel Villalpando, Michael Piore, Gilbert Cardenas, and Toni Breiter, rejected the common assumptions that illegal aliens from Mexico and other Third World countries pay little in taxes, generate high social assistance costs, displace native workers, adversely affect the nation's balance of payments, or always seek permanent settlement. ${ }^{92}$

In elaboration on such a study of San Diego County, Villalpando and others pointed out that in 1975-the depths of the recession in Los Angeles-2,154 jobs were opened by the removing of illegals, but the State Human Resources Development Agency could not fill them. ${ }^{93}$ Moreover, when the INS opened 340 jobs in San Diego County in 1975-1976 under an Employer Cooperation Program, the jobs could be filled only by greencard commuters from Tijuana. Half of those jobs were in the hotel-motel business and paid $\$ 2.00$ per hour and tips. ${ }^{94}$ Villalpando calculated that a welfare family of five could then receive about $\$ 4,800$ annually tax free (plus food stamps, health care, and other subisides), but that a family head working alone could not have made that much at $\$ 2.00$ to $\$ 2.50$ per hour. He therefore concluded that, "it is unlikely that persons eligible for welfare benefits would work for the wages that the majority of illegal aliens receive."95

In another example of revisionist thinking, Michael Piore, an M.I.T. economist, provided a more controversial perspective. By holding wages down, he argued, illegals encouraged labor-intensive industries to remain in a given place and to discourage automation. "In this sense, the presence of aliens serves to preserve native jobs." And he warned, "any wholesale attempt to end the migration is, therefore, likely to be exceedingly disruptive to the operations of the society." 96 This argument, elaborated in subsequent writings and in congressional testimony, seemed to match the warnings of Cornelius, Bustamante, and Mexican officials that any police-like cutoff of transborder labor migration would threaten economic stability in Mexico and civil liberties in both countries. From this perspective the only justified action, if any, would be a massive work permit program or some form of mass amnesty. ${ }^{97}$

92. See M. Villalpando, A Study of the Socioeconomic Impact of Illegal Aliens ON THE County of SAN Diego (1977); Breiter \& Barceló, Hispanics on Welfare: The Facts and the Figures, AGENDA, Mar.-Apr. 1977, at 4, 4-10; Cardenas, United States Immigration Policy Toward Mexico: An Historical Perspective, Chicano L. Rev., Summer 1975, at 66, 80-81, 88-89; M. Piore, Undocumented Workers and United States Immigration Policy (M.I.T. offprint 1976).

93. M. Villalpando, supra note 92 , at 53-61.

94. Id. at $58-60$.

95. Id. at $60-61$.

96. Piore, Illegal Immigration to the United States: Some Observations and Policy Suggestions, in NATIONAL Council on Employment Policy, Illegal Aliens: An Assessment of the Issues 28 (1976).

97. Id. For Piore's full interpretation of the economic role of immigrant labor in the U.S. economy,

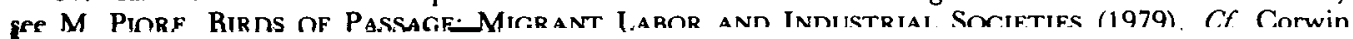

Mexican Policy and Ambivalence Toward Labor Emigration to the United Stales, in IMMIGRANTS-AND IMMIGRaNTS: Perspectives ON Mexican Labor Migration to the United States 176, 201-02, 208-09 (A. Corwin ed. 1978) (delineating Mexican officials' position). 
On the other hand, there are researchers, including North and Houstoun, who acknowledge both the need of some employers for alien labor and the exaggerations of the restrictionists, and yet insist that illegal aliens undermine wage and labor standards, force local labor either to move out or to go on social assistance, and sooner or later settle down and compete for the better jobs.

With respect to Mexican illegals in particular, economists Vernon M. Briggs, Walter F. Fogel, and Fred H. Schmidt, and political scientist Richard Sterling, have emphasized that the Mexican influx is so massive and so concentrated in certain economic sectors such as field labor and in certain geographical regions such as the southwestern border states that even yesterday's "wetback" is adversely affected. ${ }^{98}$ Ray Marshall, University of Texas labor economist, rejected facile comparisons between Europe's guestworkers and the massive border spillover from Mexico. He maintained that the massive presence of illegal aliens from Mexico and other Third World countries made it virtually impossible to bring down American unemployment rates. ${ }^{99}$ Later, speaking as Secretary of Labor in the Carter administration, Marshall estimated in 1980 that if all illegal jobholders could be removed, the national rate of unemployment would drop to $4 \% .{ }^{100}$ It was then around 7\%. More recently, Donald Huddle, who researched the boomtown Houston area, has suggested that the Federal Government itself is a major employer of illegal aliens through a system that favors contractors who make lower bids on construction projects because of illegals in the work crews. ${ }^{101}$

The Select Commission was charged with assessing, among other things, the socioeconomic impact of immigrants. It solicited a number of significant studies from immigration and labor experts, but it did not itself undertake any field studies of illegal residents, nor provide funding for such studies. ${ }^{102}$ This was partly because much more was expected from the major field surveys then being undertaken by Reyes Associates, by Mexico's CENIET surveys, and from the 1980 census. In any event, SCIRP has been criticized for not generating studies leading to more empirical data about illegal aliens. ${ }^{103}$ Moreover, it has been faulted for reaching policy recommendations-such as amnesty for illegals who entered the country before 1980, higher immigration ceilings, and a special one-time allotment of 500,000 visas-to absorb illegal alien pressures when no firm demographic data

98. See V. Briggs, W. Fogel \& F. Schmidt, The Chicano Worker 93 (1977); W. Fogel, supra note 12, at 154-58; Briggs, Mexican Workers in the United States Labor Market: A Contemporary Dilemma, 112 INT'L LAB. REV. 351, 361-62 (1975); R. Sterling, International Labor Markets: The United States-Mexican Case 1-5 (Sept. 1974) (unpublished manuscript).

99. Marshall, Economic Factors Infuencing the International Migration of Workers, in VIEws ACROSS THE Border: The United States and Mexico 175-77 (S. Ross ed. 1978); see also What Illegal Aliens Cost the Economy, BuS. WK., June 13, 1977, at 86, 87.

100. See Funds to Help Jobless Scraping Bottom, U.S. News \& WORLD REP., June 30, 1980, at 66; see also F. Marshall, Illegal Immigration: The Problem, the Solutions (FAIR Immigtation Paper No. 3 , 1982); Immigration Law Reform, San Francisco Chron., May 26, 1981, at 4A, col. 1 (editorial).

101. Press release on research findings of Professor Donald Huddle, Dep't of Economics, Rice University (Oct. 1981).

102. See supra notes $79-84$ and accompanying text.

103. See Joint Hearings, supra note 83, at 457, 467, 511, 524-25, 530-31, 535 (opinions of L. Bouvier, Population Reference Bureau; D. North, New Transcentury Foundation; and Michael Teitelbaum, Ford Foundation). 
was available on the size of the illegal alien population or on the number of immediate relatives that might be brought in by legalized aliens. ${ }^{104}$

Other studies that provide socioeconomic profiles of certain illegal alien groups have continued to emerge. David S. North's Government Records: What They Tell Us About the Role of Illegal Immigrants in the Labor Market and Income Transfer Programs, ${ }^{105}$ is a revealing followup study of a group of 580 illegal aliens, mostly Mexican, who were originally apprehended in 1975 and whose identity and contacts with various income transfer programs and the labor market could be traced through INS apprehension records and valid social security numbers.

Among North's findings were the following: a high rate of return to the U.S. labor market after apprehension (for example, of 192 members of the study group apprehended in California, 147 subsequently had earnings recorded by the California state unemployment insurance system); a high rate of filing for unemployment benefits but not social security benefits; a high rate of having taxes deducted from paychecks; a low rate of acquiring legal status and U.S. citizenship; longer duration of stays; and a continuing pattern of lower wage levels for illegal workers. The North study also contains a convenient listing of other important socioeconomic surveys of illegal alien groups as seen in table 14 .

The above listing of field studies, together with the research of North and others, helps fill in a socioeconomic profile of illegal aliens. It also serves to suggest to what extent illegal aliens-especially the Mexican migrant labor class-may be using tax-supported services. Still, one finds virtually no available data on the extent to which any "undocumented" groups use private philanthropic services such as Catholic and Protestant migrant ministries, community funds like United Way, or adult education programs. Moreover, there is at most only fragmentary data on "undetected" aliens and their families who commonly use costly public assistance programs, such as public health services, public education, public housing, and food stamps. ${ }^{106}$

One notable exception to this general lack of data is a major study of Mexican aliens in San Diego County that builds on the earlier study by Villalpando and associates. ${ }^{107}$ Prepared for the county government by Community Research Associates in May, 1980, Undocumented Immigrants: Their Impact on the County of San Diego is in some ways a model of informative research about elusive illegal aliens. ${ }^{108}$ Aside from information collected from numerous federal, state, and county agencies, trained Spanish-speaking researchers used a variety of research methods and

104. Id.

105. D. North, Government Records: What They Tell Us About the Role of Illegal Immigrants in THE Labor MaRket and Income Transfer Programs (1981) (prepared for U.S. Dep't of Labor, with assistance of $J$. Wagner).

106. See U.S. Comptroller General (GAO), Report to the Congress of the UNITED StATES: Illegal Aliens: Estimating Their Impact on the United States 2 (1980); see also A. Corwin, A Tale of Woe: Report on Immigration Manpower Needs in Select Areas (Apr. 20, 1981) (unpublished manuscript prepared for Hoover Institution) (reporting author's interviews with immigration officers and border patrolmen during winter and spring of 1981).

107. See supra note 93 and accompanying text.

108. In the preparation of this study, William Bramberger served as a subcontractor, Alfredo Velasco as a consultant, and Alberto Attia as an associate researcher. Other individual participants in the study were too numerous to mention. 


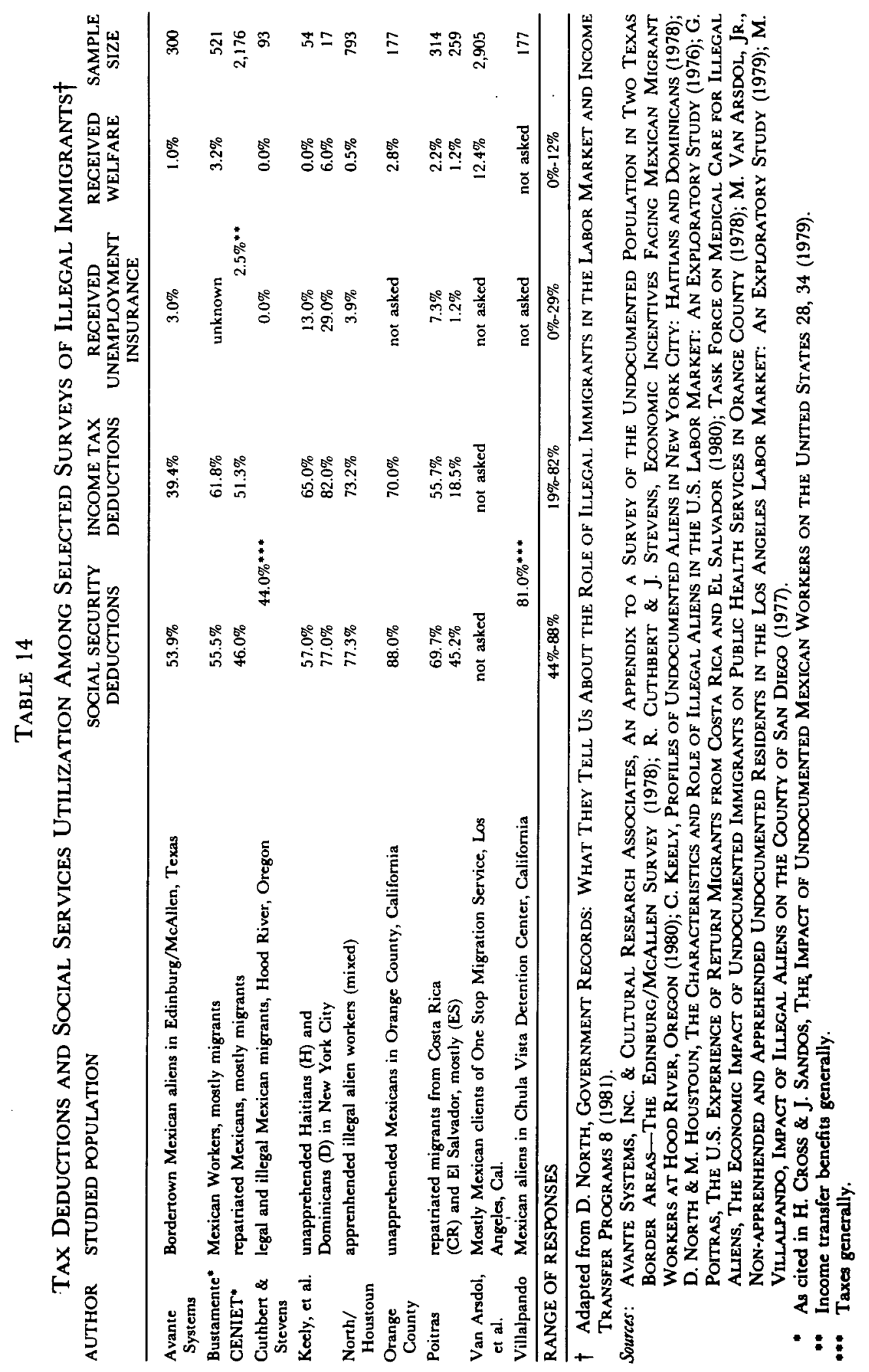


informant samples of various sizes. ${ }^{109}$ Some of the results are as follows. There were an estimated 25,000 to 48,000 illegal immigrants living in San Diego County. Of these between 13,000 to 25,000 held jobs in the regional labor force, contributing possibly $0.5 \%$ to the local unemployment rate. The removal of these undocumented workers would presumably involve short-term disruptions in the regional economy, particularly in the agri-labor sector where they made up $34 \%$ to $59 \%$ of the hired labor force, and in the restaurant and hotel-motel business. In 1979 , these workers paid an estimated $\$ 5,900,000$ to $\$ 11,800,000$ in job-related taxes and insurance, but illegal agri-workers probably paid no federal or state income tax. One third of the firms surveyed in San Diego and Orange counties were found to be violating minimum wage and overtime standards.

The monetary impact of illegal aliens on the county welfare system was minimal because, unlike most other states, California requires proof of legal residency or citizenship before benefits are issued. ${ }^{110}$ The total unpaid billings for all the hospitals in the county ranged from $\$ 4,400,000$ to $\$ 8,200,000$. The estimated undocumented student population in county schools, from kindergarten through twelfth grade, ranged from 6,034 to 11,662 . The cost of schooling illegals ran from an estimated $\$ 10,900,000$ to $\$ 21,000,000$, or from $1.9 \%$ to $3.7 \%$ of the total county school costs. In fiscal 1979, over 384,000 illegal entrants were arrested in the borderline counties of San Diego and Imperial. Of that number 9,811 were remanded to the U.S. Marshal. These persons comprised 85\% of the prisoners in the Metropolitan Correctional Center; of that percentage, material witnesses accounted for $52 \%$, alien smugglers for $15 \%$, with fraudulent documents and illegal re-entry cases constituting the remainder.

Local government officials are increasingly concerned with the social and labor-displacement costs associated with uncontrolled migration. A significant indicator of this concern is a detailed socioeconomic profile of the undocumented Mexican migrant population of Texas. This study was hurriedly done in MarchJuly 1982 for the Governor's Task Force on Illegal Aliens by Lance Tarrance and Associates, specialists in public-opinion surveys. ${ }^{11}$ Using random samples, the researchers interviewed 1,443 migrant workers apprehended by the Immigration Service and 2,312 informants throughout the state-including 620 citizens of U.S.Hispanic descent - to help fill out the social profile. Among the findings, about $60 \%$ of undocumented workers would choose a "temporary work permit" if given

109. The samples included 50 undetected aliens, 405 "Silva cases," 665 aliens in the Metropolitan Correctional Facility, and 187 employers. Community Research Associates, Undocumented Immigrants: Their Impact on the County of San Diego (May 1980) (prepared for county government). "Silva cases" are quasi-legal Mexican workers, usually with families in the United States, who remain in this country under stays of deportation while the Immigration Service determines their eligibility for "recaptured visas" mistakenly awarded to Cuban immigrants prior to 1976. Silva-case families were generally quite willing to be interviewed, thus presenting Community Research Associates with an unusual research opportunity.

110. Cal. Welf. \& INST. CODE $§ 11104$ (West 1980).

Regulations promulgated under this statute require the alien to submit Form CA-6 ("Alien Status Verification"). The statute provides that benefits are obtainable upon the filing of certification, but entitlements are subject to confirmation of status by the U.S. Immigration and Naturalization Service. Id.

111. Office of Governor, State of Tex., A Study of Undocumented Workers in the State of Texas, March-July 1982 (F. Newport, Director 1982). 
the chance. ${ }^{112}$

Policymakers in the United States and Mexico thus have at hand a substantial accumulation of socioeconomic information about "undocumented" Mexicans who are commonly thought to constitute around $60 \%$ of all illegal aliens in the United States. The problem is that there is no comparable profile information about other fast-growing groups of illegal aliens, such as Filipinos, Orientals, Colombians, Haitians, Dominicans, or Salvadorans, although occasionally a study is concerned with some of these groups. ${ }^{113}$

\section{VII}

\section{The Mexico Side of The "Numbers Game"}

\section{A. Official Attitudes of the Mexican Government}

Mexican officials and editorialists were alarmed at the rapid emergence of an immigration restrictionist movement in the United States during the early 1970's. Of particular concern were the Rodino bills during the period 1971-1975 that would have applied sanctions to employers of illegal aliens. ${ }^{114}$ Facing a population explosion and a serious trade deficit with the United States, Mexican authorities were determined to keep open a border safety valve.

In the fall of 1972, through the initiative of President Luis Echeverria, both governments agreed to set up interagency study groups to examine independently migrant labor problems and to exchange proposals on what could be done through binational cooperation. ${ }^{115}$ An interagency Commission for the Study of Surreptitious Labor Emigration was thereupon established in Mexico's Ministry of Foreign Affairs. The Nixon administration set up a similar group, the so-called Cramton Commission.

Foremost in the mind of the Mexican Government was protecting Mexican access to jobs in the United States. It also wanted the most humane treatment possible for deportees and American assistance in collecting unpaid wages. President Echeverria also sought to revive the binational Bracero labor program abandoned by the American Government in 1964. The Cramton Commission had principally in mind greater cooperation from Mexican officials in controlling illegal migration and alien smuggling. ${ }^{16}$

In spite of an increased number of consular offices in the United States, the

112. Id. at $5-9,155-56,165$.

113. Stepick, Root Causes of Haitian Migration, in Immigration Reform. Hearings Before the Subcomm. on Immigration, Refugees and International Law of the House Comm on the Judiciary, 97th Cong., 1st Sess. 698-762 (1982). For a guide to other academic and government works that seek to assess the socioeconomic impact of "undocumented" immigrants, see J. VIALET, supra note 2. See also U.S. CoMPTROLLER GeNERAL, supra note 106; U.S. Select Comm'N ON Immigration and Refugee Policy, U.S. Immigration Policy AND The National INTERest: Staff Report (L. Fuchs ed. 1981).

114. See J. Vialet, Illegal/Undocumented Aliens 4-5 (July 31, 1981) (Issue Brief 74137, Congressional Research Service); see also Corwin, supra note 97, at 202.

115. Corwin, supra note 97, at 197, 199.

116. See Office of AtT'y General, U.S. Dep't of Justice, A Program for Effective and Humane Action on Illegal Mexican Immigrants: Final Report of the Special Study Group 1 8 (1973) (R. Cramton, Chairman). 
Mexican government in 1972 had practically no statistical knowledge of Mexicans furtively there. At that time, Mexican government agencies were no more prepared to do research on illegal migration than American agencies. For statistical information about Mexicans illegally in the United States both governments had to turn to the INS which could only provide rising apprehension figures. These always alarmed sensitive Mexican nationalists. Arrests of Mexican citizens by the hated Migra (Mexican slang for the INS) shot upwards from 55,349 in fiscal year 1965 , when the Bracero program ended, to 430,200 in fiscal year 1972, with no sign of a letup. ${ }^{117}$

Mexican officials decided they wanted their own independent statistical evaluation of the "new wetback problem" in the United States. Consequently, for the first time, the Mexican Government, through its interagency commission, undertook serious research on the phenomenon of surreptitious emigration. It was decided that the simplest way to gather field information was to interview Mexican deportees unloaded at specific points in Mexico by the American immigration officers under the nonpenalty "voluntary departure" system. During the period 1972-1974, study commission officials gathered interviews from more than 3,000 deportees. In addition, consular officers and researchers from ministries, such as Labor and Social Welfare, contributed special reports to the commissioners. ${ }^{118}$

The commission found that depending on the season, an estimated 1,000,000 to $2,000,000$ compatriots lacking proper authorization were working or seeking work in the neighboring republic. Around 1973, these people were sending home somewhere near $\$ 1,000,000$ a year, in addition to whatever they carried on their person. Wage averages of deportees, most of whom were unskilled or semiskilled workers in agri-industries, were somewhat less than $\$ 1.50$ an hour. The American minimum wage then was from $\$ 2.00$ to $\$ 2.50$ an hour (but some migrant workers were given room and board free). Wages were notably higher in the interior of the United States and notably lower in an immediate border area flooded with Mexican labor. ${ }^{119}$

Most informants, nearly all males, were originally rural campesinos whose subsistence village economy had come to depend on dollar earnings. When the Bracero program closed in 1964, and indeed long before that, they simply continued to migrate to the United States, with or without permiso. The typical age group was sixteen to thirty. Mexican officials were shocked to learn that in this category were grown men who had never tried to work in Mexico. They uniformly protested their love for la madre patria but complained of low wages for unskilled labor in Mexico, then from $\$ 1.00$ to $\$ 5.00$ per day in U.S. currency. Everyone knew, they explained, about the good wages on the other side. Although Mexican officials promised that $e$ Presidente would provide jobs for repatriates in new industrial and agricultural programs, apparently most deportees were determined to

117. Corwin, supra note 97 , at $196-98$.

118. Interviews with members of Mexico's Intersecretarial Commission on Surreptitious Emigration, in Mexico City (Apr. 3 \& 10, 1975).

119. See Comisión Intersecretarial para Estudio del Problema de la Emigración Subrepticia de Trabajadores Mexicanos, Informe de ACtividades y Recomendaciones 9-14 (1972). 
return to the United States "just as soon as they finished lunch."120

The study commission found also that many deportees were no longer content with agri-labor in the United States but were seeking higher wages in service and industrial employment there. They learned further from deportees and consular reports that better-paid Mexican nationals in services and industries were largely going undetected in the American economy, and that increasingly Mexican industrial workers were leaving jobs in Mexico for better wages in the American labor market.

TABLE 15

TyPe of JOB Held in MEXico by UNDOCUMENTEd IMMIGRANTS Recently DePORTED by U.S. IMMIgRation Authorities (IN PERCENTAGES)

\begin{tabular}{|c|c|c|c|}
\hline Type of Job & $\underline{1972}$ & 1974 & 1975 \\
\hline Employer or business owner & 1.7 & 2.2 & 2.7 \\
\hline Self employed & 5.5 & 6.1 & 7.1 \\
\hline Land holder (ejidatario) & 4.4 & 12.9 & 4.3 \\
\hline Landless agri-worker & 43.1 & 35.1 & 35.6 \\
\hline Industrial worker & 15.8 & 18.0 & 21.5 \\
\hline Services worker & 17.8 & 18.0 & 18.6 \\
\hline Wageless family worker & 5.7 & 4.0 & 3.9 \\
\hline Never employed before & 6.1 & 4.2 & 6.3 \\
\hline Total & 100.0 & 100.0 & 100.0 \\
\hline $\mathrm{n}=$ & 2,791 & 1,316 & 1,658 \\
\hline
\end{tabular}

$\mathbf{n}=$ number of interviewees

Source: Results from interviews with Mexican deportees in eight border cities in 1972, 1974, and 1975, done by Comisión Intersecretarial para el Estudio del Problema de la Emigración Subrepticia de Trabajadores Mexicanos a Estados Unidos de América, Secretaria de Relaciones Exteriores, Mexico City. Adapted From Bustamante, Undocumented Immigration From Mexico: Research Report, 11 INT'L MigRation Rev. 162 (1977).

With this new information in hand, and considering the dramatic increase in arrests of Mexican nationals by the INS (709,459 in fiscal 1974 alone), Mexican officials no longer saw much point in insisting on a renewed Bracero program for perhaps 200,000 or 300,000 agri-workers. Such an arrangement obviously would not cover better-paid mojados ("wetbacks") already in industrial and service work abroad, nor legalize more than a small part of the campesinos seeking agribusiness work in the United States.

In a border meeting in October, 1974, President Echeverría told President Ford that Mexico was no longer actively seeking a new contract labor program. ${ }^{121}$ By then the Mexican Government had decided to develop labor-intensive industries to absorb surplus labor and to concentrate its emigration policy on protecting

120. Interview with Juan Barona Lobato, Director of Migratory Affairs, Mexican Ministry of Foreign Relations, Mexico City (Jan. 21 \& 31, 1974); Interview with Victor Ramirez, Deputy Director of Human Development Studies, Institutio de Estudios Políticos, Económicos, y Sociales, Mexico City (Feb. 12, 1974).

121. Corwin, supra note 97 , at 199-200. 
its vested interest in the U.S. labor market. The official position became explicit: there are no illegals in the United States, and no apologies. There are only "undocumented workers" who subsidize the American economy and the American welfare state, and who deserve full human rights. Thereafter Mexico's protectionist strategy included pressing American officials to accept the term "undocumented worker" and a concept of international labor rights much like that recommended for European "guest workers" by the Geneva based International Labour Organization. ${ }^{122}$

Mexican officials and negotiators could now use their own statistical facts to serve protectionist needs. For example, they challenged the "exaggerated" 1975 estimate of the Lesko study that an estimated 5,200,000 Mexicans were settled illegally in the United States, as well as the common estimate of American immigration officials that $60 \%$ or more of the annual inflow of permanent illegal settlers were of Mexican origin. Mexican data indicated that in many cases the same undocumented workers were repeatedly arrested while attempting to reach job sites in the United States, thus leading to a grossly exaggerated view of the "Mexican invasion" as reflected in U.S. apprehension statistics. ${ }^{123}$

In this manner, Mexican officials contested the meaning of the "alarmist" immigration-arrest figures circulated during the recession of 1973-1975 by the INS under Commissioner Chapman. Just as the Commissioner played up Mexican apprehensions to get more enforcement legislation and resources, the Mexican government began using statistics to play down enforcement needs, keeping its safety valve open.

\section{B. Revisionist Studies}

After 1974 Mexico's position on undocumented nationals in the United States was reinforced and publicized by an emerging group of revisionist scholars. Chief among the revisionists is Mexico's Jorge Bustamante, a professor of sociology at El Colegio de Mexico, a center of graduate studies and research in the social sciences in Mexico City. Bustamante, who has a doctoral degree in sociology from the University of Notre Dame and who has been associated with the Chicano Studies Center there, established himself during the Echeverría administration (19701976) as Mexico's leading authority on emigration studies. He is also foremost among a new genre of advocate scholars who seek to change government policies in both countries and defend the international rights of the working class at home and abroad.

While doing participant-observer research on mojado emigration in 1969, Bustamante himself crossed the Texas border as a "wetback." Since then he has interviewed large samples of Mexican deportees and voluntary returnees, and has written numerous chapters, reports, and position papers. In 1975, Dr. Bustamante became President Echeverria's chief consultant on labor emigration to the United

122. Id. at 203; see also Excelsior (Mexico City), Nov. 18, 1976, at 19A

123. Interview with Juan Barona Lobato, supra note 120; Interview with Victor Ramirez, supra note 120 . 
States. Later, as head of the Center for Border Studies of Northern Mexico, he directed a series of border research studies. ${ }^{124}$

Bustamante's findings supported the Mexican official view that most undocumented border crossers were either cyclic agri-workers or unskilled and semi-skilled workers in the U.S. secondary labor market, and in neither case did they pose a serious competitive threat to American workers. Nor were they a burden on American tax-supported services. In one study of several hundred deportees, Bustamante found that only $2.3 \%$ had used welfare services and only $7.8 \%$ had used public health services. ${ }^{125}$ Professor Bustamante's research is especially valuable for demonstrating the growing links of interdependency between the American labor market and Mexico's migrant labor force, as suggested by the following table.

Meanwhile, Bustamante developed a neo-Marxist interpretation of labor emigration from Third World countries which is widely shared by Mexican and Chicano leaders of la Raza. According to this thesis, Mexico has historically provided, and still provides, the main source of proletarian immigrant labor for the development of the American Southwest and many special sectors of the American economy, including agriculture, railroads, mines, garment shops, and factories, as well as maintenance, construction, and service industries, including domestic service. The unpaid surplus value of Raza labor serves to increase American corporate wealth and capitalist expansion both in the United States and in Mexico itself. In turn, this contributes to maintaining a colonial relationship between the two countries, at the same time serving to support a privileged standard of living for the Anglo-American capitalist class, and, incidentally, for Mexico's collaborating elite. ${ }^{126}$

By doing work that Americans refuse to do, by laboring at low wages, by paying taxes in most cases, and by making little use of American social services, Mexico's undocumented migrant workers (unable to survive at home in a regressive colonialist structure) provide a major subsidy for the American economy that neither government can ignore. From this fact is derived, in Bustamante's term, "the rights of the undocumented taxpayers." To this is added a "moral right" to an open border since the American imperialists expropriated Mexican territory in 1848. ${ }^{127}$ Adhering to this interpretation, Mexican and Chicano labor organiza-

124. See Corwin, The Study and Interpretation of Mexican Labor Migration: An Introduction, in IMMIgrants-and Immigrants: Perspectives on Mexican Labor Migrition to the United States 11 (A. Corwin ed. 1978).

125. Bustamante, Undocumented Immigration from Mexico: Research Report, 11 INT'L Migration REv. 170 (1977); see supra notes 86-113 and accompanying text.

126. Bustamante, Commodity Migrants: A Structual Analysis of Mexican Immigration to the United States, in Views ACross the Border: The United States and Mexico 183 (S. Ross ed. 1978).

127. Id.; see also Bustamante, The Historical Context of the Undocumented Immigration from Mexico to the United Stales, 3 AzTlan-INT'L J. Chicano Stud. Research 257 (1972).

For a survey of similar Chicano interpretations, and of contrasting "establishment school" approaches, see Corwin, Mexican-American History: An Assessment, in The Chicano 1, 6-8, 32-33, 36, 40 (N. Hundley ed. 1975).

Perhaps the most extreme formulation of Chicano ideology is that which regards the Anglo-American United States citizen as the true illegal alien. See R. Acuna, Occupied America: The Chicano's StrugGle Toward Liberation 210, 220-31, 274-77 (1972). 


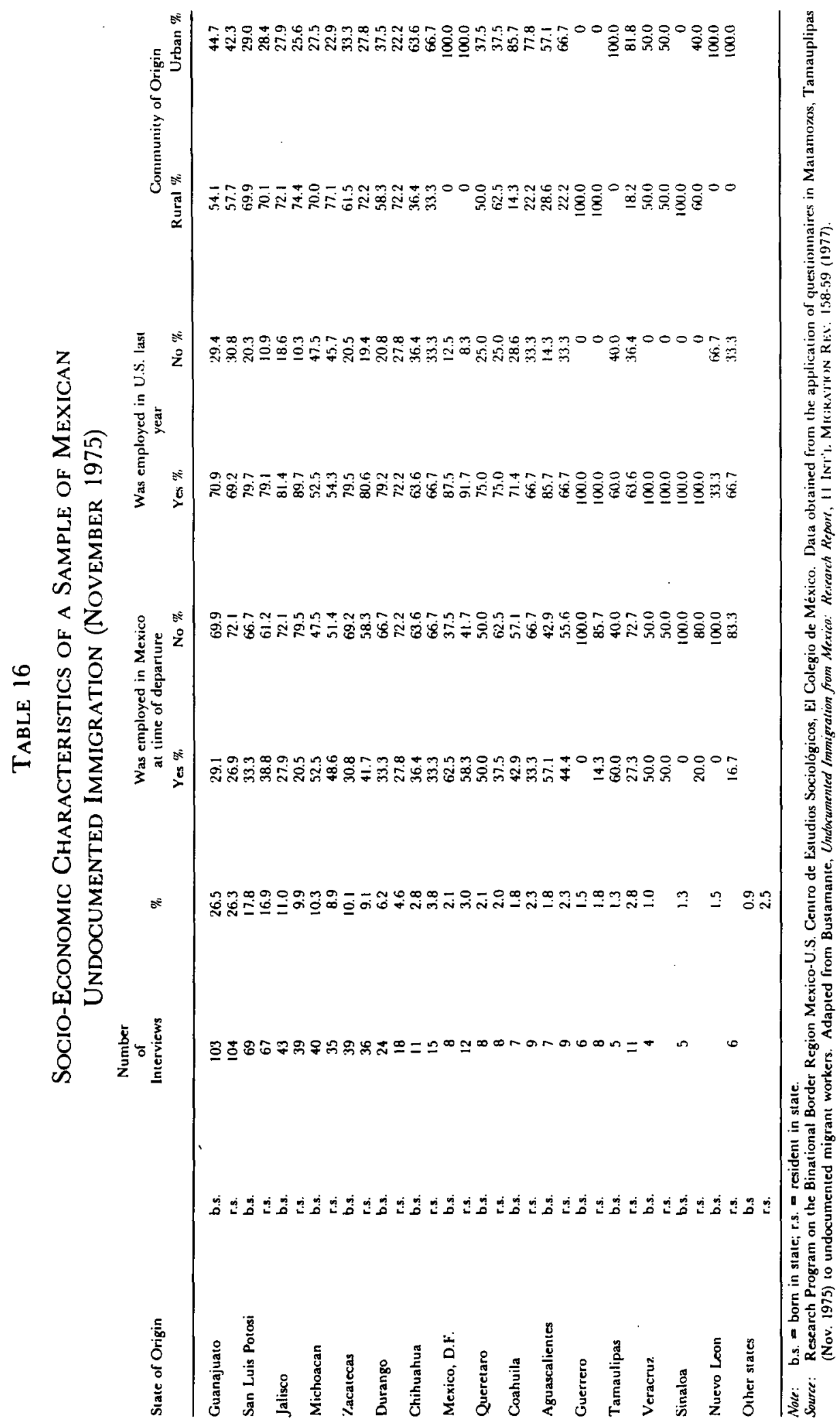


tions, who seek to achieve a transborder solidarity movement and free access to either labor market have declared a sweeping "Bill of Rights for Undocumented Workers." 128

Another revisionist thesis, also giving support to the official Mexican view that American officials, legislators, and labor leaders tend to exaggerate the numbers and the adverse social impact of Mexican immigrants, has been developed by $\mathrm{Dr}$. Wayne Cornelius. Dr. Cornelius, a political scientist, was at Massachusetts Institute of Technology and now is at the University of California, San Diego, where he directs the Center for United States-Mexican Studies. Since 1973, Dr. Cornelius has done extensive field studies particularly of villages in the State of Jalisco from which three generations of seasonal workers have come to the United States. Like Bustamante, Cornelius holds that such migrants are no serious threat to the American job market because they do low-pay, short-term work that for the most part requires great mobility, and because they return cyclically to Mexico. Both researchers tend to ignore other currents of permanent Mexican immigration to the United States. ${ }^{129}$

According to the Cornelius profile, migrants from Jalisco villages, and other central Mexico villages, are mostly younger men who, if married, leave their families behind. They save a high percentage of their earnings and make very little use of American social, health, or educational services. Returning to Mexico, they use their savings to advance small business or property interests. ${ }^{130}$ (One might here question whether or not these small proprietors, landholders, tradesmen, and shopkeepers are typical of the "landless lumpenproletariat" found in so many other parts of Mexico and along the Mexico-U.S. border.)

Unlike Bustamante, who tends to stress capitalist exploitation of a defenseless labor class, Dr. Cornelius emphasizes that both countries benefit from this symbiotic form of foreign aid. Also, according to the thesis, any attempt by American authorities to cut off the flow of cyclic migrants would be counterproductive, ${ }^{131}$ serving only to profit alien smugglers and to force Mexican migrants to settle down on the American side. Instead of trying to stop it, why not regulate it? After all, nearly three quarters of the Jalisco migrant workers studied by Cornelius returned to their native villages.

Professor Cornelius, who has urged his interpretations in position papers and in

128. Apart from the labor organizations, Chicano rights organizations, legal services offices in the barrios and colonias, and other groups with a protectionist mission commonly circulate declarations of rights of the undocumented international worker. Such groups include the Chicano Awareness Center of Omaha, the Committee on Chicano Rights, Inc., of National City, Cal., the Legal Aid Society of San Diego, the Manzo Area Council of the Legal Service Center of Tucson, and Centro Aztlan of Houston.

129. See infra notes 136-52 and accompanying text.

130. See W. Cornelius, Illegal Mexican Migration to the United States: A Summary or Recent Findings and Policy Implications 8-13 (M.I.T. Center for Int'l Studies 1977); W. CoRnelius, Mexican Migration to the United States: Causes, Consequences and U.S. Responses 5-9, 2939 (M.I.T. Center for Int'l Studies 1978); W. Cornelius \& J. Diaz Canedo, Mexican Migration to the United States: The View from the Rural Sending Communities $31-41$ (M.I.T. Center for Int'l Studies 1976).

131. For the gist of Cornelius' arguments against cutting off the migrant Mexican labor flow, see W. Cornelius, Illegal Mexican Migration to the United States, supro note 130, at 8; W. Cornelius \& J. Diaz CANEDO, supra note 130 , at 44-49. 
congressional testimony, would have the American Government issue 750,000 Mexican labor permits according to seasonal demand as a means of solving most of the border migration-control problem. That number would cover most of the perennial migrants or "repeaters," and would also liberate the Border Patrol from a fruitless and thankless task. ${ }^{132}$ According to Cornelius, an appropriate month-bymonth distribution of visas issued during the first year of the system would be as follows:

\section{TABLE 17 \\ Distribution OF VISAS}

\begin{tabular}{|c|c|}
\hline Month: & Maximum number of Visas to be issued: \\
\hline January & 50,000 \\
\hline February & 200,000 \\
\hline March & 200,000 \\
\hline April & 100,000 \\
\hline May & 50,000 \\
\hline June & 50,000 \\
\hline July & 50,000 \\
\hline August & 25,000 \\
\hline September & 25,000 \\
\hline October & 0 \\
\hline November & 0 \\
\hline December & 0 \\
\hline TOTAL: & 750,000 \\
\hline Source: $\begin{array}{r}\text { Co } \\
\text { IM } \\
\text { OF } \\
\text { RA }\end{array}$ & $\begin{array}{l}\text { igrant Workers from Mexico: A Proposal, in U.S. } \\
\text { INTEREST: APPENDIX F TO STAFY REPORT } \\
\text { AND REFUGEE POLICY, PAPERS ON TEMPO- }\end{array}$ \\
\hline
\end{tabular}

When the President of Mexico, Jose Lopez Portillo, inaugurated in November 1976, met with American president Jimmy Carter in February 1977, he presented the Mexican side of the argument using some elements of the Bustamante and Cornelius theses. Lopez Portillo vehemently opposed any "police solutions" to the border control problem. He warned an impressionable Carter that to cut off the escape valve for Mexican labor emigration would be economically harmful for both countries, and could even lead to serious, perhaps revolutionary, political repercussions in Mexico. ${ }^{133}$ The Mexican president urged Carter not to raise the level of immigration enforcement while Mexico sought "a long range solution" by promoting industrial development and family planning. He did agree, however, to cooperate with American officials in the pursuit of alien smugglers who, increasingly, were transporting Central Americans and South Americans across Mexico to the porous American frontier. ${ }^{134}$

132. Cornelius, Legalizing the Flow of Temporary Migrant Workers from Mexico: A Proposal, in Appendix F to SCIRP FinAL REPORT, supra note 70, at 315; see also W. CoRnelius, Building the CaCTus CuRTAIN: MEXico AND U.S. RESPONSES From WILSON TO CARTER (forthcoming); Bustamante, Mexican Undocumented Immigration: A 'Domestic' Problem, Migration TODAY, June 1978, at 7, 7-10; Cornelius, Undocumented Immigration: A Critique of the Carter Administration's Policy Proposals, Migration Today, Oct. 1977, at 5, 5-8, $16-20$.

133. See Corwin, supra note 97, at 206-11; Corwin, supra note 86, at 331-32.

134. See Corwin, supra note 86 , at 331 . 
In August 1977, the Carter administration proposed not only an amnesty program for Mexican and other illegal aliens, but a higher level of border patrol enforcement as well. ${ }^{135}$ Adverse public opinion on amnesty and the opposition to immigration law enforcement by spokespersons for the Hispanic vote, together with confirmation of huge oil discoveries in Mexico, led both governments to agree that the whole subject of immigration policy deserved less action and more study. In the United States this took the form of the President's Select Commission on Immigration and Refugee Policy (SCIRP) (1978-1981) and in Mexico the CENIET surveys (1978-1980).

\section{Mexico's CENIET Surveys}

In 1977 a number of social scientists proposed that the Mexican Government sponsor and fund the most complete field surveys ever undertaken of Mexican labor migration to the United States. The administration of President Lopez Portillo agreed with the proposal because of the fear that the growing importance of both legal and "undocumented" emigrant workers to the Mexican national economy and the controversy surrounding "exaggerated numbers" might lead to unwarranted restrictive measures against Mexican migrants by the American Government. Consequently, the National Center for Labor Information and Statistics (Centro Nacional de Información y Estadística del Trabajo), a research agency associated with the Ministry of Labor and Social Welfare (Secretaria del Trabajo y Prevision Social) became the coordinating center for the so-called CENIET Surveys. ${ }^{136}$ Essentially, the surveys sought to determine how many Mexican workers legally or illegally crossed the U.S. border annually, and how many actually remained in the United States more or less permanently. The surveys also hoped to determine the economic character and importance of internal and external labor migration to Mexico's economy.

While the CENIET surveys were the result of careful, collaborative efforts involving sociologists, demographers, economists, political scientists, government employees, and hundreds of interview trainees, three revisionist scholars with a keen interest in public policy had a special influence in shaping the monumental design: Jorge Bustamante, ${ }^{137}$ Manual García y Griego, ${ }^{138}$ a Mexican-American demographer, and Wayne Cornelius. ${ }^{139}$

In the primary stage elaborate samples of migration histories were collected in a "First Border Survey" in October-November 1977. Data was collected from two groups: apprehended persons returned to Mexican border port-of-entry by American immigration officers, and a smaller group of voluntary returns. Special attention was given to the duration of stay in the United States, type of employment, payroll deductions, if any, use of social services, and voluntariness of return. Inter-

135. President's Message to Congress on Undocumented Aliens, 13 Weekly Comp. Pres. Doc. 1170 , 1171, 1174-75, (Aug. 4, 1977).

136. For information about development of the CENIET surveys, see APPROACHES, supra note 49.

137. See supra notes $124-35$ and accompanying text.

138. Mexican-American demographer, associated with El Colegio.

139. See supra notes $129-32$ and accompanying text. 
view data was compared to INS deportation figures for Mexican aliens during period 1970-1977. In order to have a more comparative and current view of the annual flow cycle, research teams collected more migration histories during a "Second Border Survey" from August 1978 to May 1979. In all, about 35,000 deportees and voluntary returnees were interviewed in the two surveys. Thus CENIET researchers gathered more interviews than all previous surveys of "undocumented" Mexican workers. ${ }^{140}$

The preliminary findings of the CENIET border surveys were first released in December 1979 and slightly revised in 1980. According to the surveys, the estimated gross annual flow of Mexican nationals, legal and illegal, to the United States between 1972 and 1976 ranged between 629,000 and 2,043,000, depending on the season. However, the net annual flow of deportable Mexican workers to the United States was estimated to be much lower: 50,000 to 158,000 . Here one must take into account that the net flow figures were for January, a low point of Mexican seasonal labor migration, and apparently did not include family members. Also, one should note that the net flow estimates for 1976 alone were notably higher: 113,000 to 284,000 . In any case, according to CENIET authors, only a small percentage of the annual emigration flow of "undocumented" Mexican migrants actually remained in the United States.

TABLE 18

Estimates of Gross and Net Flow of Deportable Mexicans in THE U.S., 1972-1977 (THOUSANDS)

\begin{tabular}{lllrr}
\hline & \multicolumn{2}{c}{ Gross Flow* } & \multicolumn{2}{c}{ Net Flow** } \\
\cline { 2 - 5 } YEAR & Low & High & Low & High \\
\hline 1972 & 645 & 1497 & 12 & 39 \\
1973 & 545 & 1770 & 28 & 131 \\
1974 & 651 & 2139 & 20 & 77 \\
1975 & 680 & 2239 & 75 & 256 \\
1976 & 799 & 2591 & 113 & 284 \\
Average & 629 & 2043 & 50 & 158 \\
\hline
\end{tabular}

* Entries into deportable status.

** The difference between entries and exits from deportable status.

Source: M. García y Griego, El volumen de la Migracion de MExicanos no docuMENTAdOS a los Estados Unidos: neuvas hipotesis Table 5.2 (1980).

The CENIET border surveys' estimate of the deportable Mexican stock population living more or less permanently in the United States in January 1977, and presumably including family members was estimated to range from 482,000 to $1,224,000$.

Demographers with the U.S. Census Bureau, believing that the CENIET

140. See APPROACHES, supra note 49, at 103-04. 
figure for the deportable Mexican stock population was unrealistically low, made a

TABLE 19

Estimates of the Number of Deportable Mexicans in the

UNITED STATES 1972-1977

(THOUSANDS)

\begin{tabular}{lcr}
\hline YEAR* $^{*}$ & LOW & HIGH \\
\hline 1972 & 234 & 436 \\
1973 & 246 & 476 \\
1974 & 274 & 606 \\
1975 & 294 & 684 \\
1976 & 369 & 940 \\
1977 & 482 & 1,224 \\
\hline
\end{tabular}

* Estimates for January of each year.

Source: M. García Y Griego, El volumen de la migración de MEXicanos no docuMENTADOS a los ESTADOS UNIDOS: NEUVAS hIPOTESIS Table 5.1 (1980).

recalculation of the CENIET estimate based on alternative reasonable assumptions concerning projected return rates to Mexico and came up with a higher estimate for January 1977: 700,000 to $2,200,000 .{ }^{141}$

A common criticism of border town surveys of returning migrants and deportees, seasonal laborers for the most part, is that they tend to ignore deportable nationals who settle, along with family members, on the American side in higherpay, year-round industrial and service jobs. To meet this criticism and to fill an informational void, the CENIET researchers were prepared to move into a second stage of research even more impressive in scope than the first stage. Stage two involved a "National Household Survey of Emigration to the Northern Border and to the United States" that was carried out December 1978 through January 1979 , in communities that historically have sent countless workers and families over the border. These communities include those in the central states of Guanajuato, Michoacan, San Luis Potosí, Jalisco, and Zacatecas and the border state of Chihuahua. Some 60,000 households in 115 different localities were visited by interview teams and asked whether any members of the household age fifteen years or older, documented or undocumented, were presently working in the United States or looking for work there. ${ }^{142}$ The Mexican national household survey estimated that the number of Mexican nationals, legal or "undocumented," age fifteen or over, at work or looking for work in the United States, and who habitually reside in Mexico was, as of January 1979, around 405,000.

141. Siegel, supra note 17 , at 16 .

142. For accounts of the National Household survey, see C. Zazueta \& R. Corona, Los trabajadores en los Estados Unidos: Primeros Resultados de la' encuesta nacional de EMIGRACIÓN (1979); C. Zazueta, Mexican Workers in the United States: Some Initial Results and Methodological Considerations of the National Household Survey on Migration (Jan. 1980) (unpublished paper prepared for Working Groups on Mexican Migrants and U.S. Responsibility, Univ. of Maryland Center for Philosophy and Public Policy). 
TABLE 20

\section{Estimated Mexican Workers in the United States in DECEMBER, 1978 AND IN JANUARY, 1979*}

\begin{tabular}{lrrr}
\hline AGE GROUPS & TOTAL & MALES & FEMALES \\
\hline $15-19$ years & 79,889 & 62,767 & 17,122 \\
$10-24$ & 106,042 & 91,812 & 14,230 \\
$25-29$ & 67,075 & 57,660 & 9,415 \\
$30-39$ & 74,892 & 69,222 & 7,670 \\
$40-49$ & 47,674 & 40,756 & 6,918 \\
$50-54$ & 13,301 & 11,903 & 1,398 \\
$55-59$ & 9,560 & 8,204 & 1,356 \\
60 years and over & 5,424 & 4,794 & 630 \\
Not reported & 1,610 & 1,288 & 322 \\
TOTAL & 405,467 & 346,406 & 59,061 \\
\hline
\end{tabular}

* Legal and "undocumented."

Source: Adapted from CENIET data, Encuesta Nacional de Emigracion a la Frontera Norte del Pais y a los Estados Unidos (ENEFNEU), Table Population V (1978-1979).

Hardly any serious students of Mexican immigration to the United States accepted the low range of certain CENIET estimates. Census Bureau demographers Siegel, Passel, and Robinson pointed out some of the possible defects. For example, during December-January. when the household surveys took place the outflow of Mexican workers would be at a minimum and the backflow at a maximum, because hundreds of thousands of legal and illegal migrants spend Christmas and most of the winter in Mexico. Moreover, since the questionnaires asked only about household members age fifteen or over at work in the United States, persons under fifteen as well as old people and housewives residing in the United States would not have been counted. In addition, there would have been a natural reluctance to report household members working illegally in the United States.

According to INS data, around 480,000 Mexicans were admitted as legal immigrants to the United States in the period July 1, 1969 to September 30, 1977. Possibly half of these were in the labor force as seasonal or permanent workers. Also, in 1977 some 930,000 legal Mexican immigrants registered under the Alien Address Program of the Immigration Service. Possibly half of this accumulated number were in the U.S. labor market, and would include an unknown percentage who actually reside part-time in Mexico. Given the foregoing data and considerations, and the fact that CENIET researchers were counting both legal and "undocumented" Mexicans in the United States, the Census Bureau demographers could only conclude, half in jest, that perhaps the Mexican national survey succeeded in counting only those Mexican nationals who had a "green card," or legal resident alien status. ${ }^{143}$

In fact, there is considerable evidence that large groups of Mexican "immi-

143. Siegel, supra note 17 , at $25-28$. 
grants" admitted legally to the United States, even those who register annually; as U.S. resident aliens, actually live in Mexico much of the year. Cornelius, in his extensive field studies of villages in the state of Jalisco, found that for several generations some village dwellers have gone to labor in the United States. Nearly all of them return seasonally and eventually permanently, even though many possess a permanent resident alien card which they regard more as a work permit than a residence permit. ${ }^{144}$ Reichert and Massey found a similar migratory backflow in their 1979 study of a village in the central Mexican state of Michoacan. Of 465 families, over three-fourths depended on migrant income from the United States. Two-thirds of the migrants had F-151 immigration cards (green cards), some of them acquired fraudulently. Since 1910 only 70 migrants had remained permanently in the United States. ${ }^{145}$ These findings are even more true of the Mexican border towns where tens of thousands of Mexicans hold legal resident alien cards, as well as border visitor or "shopping cards," yet prefer to live on the Mexican side and commute daily or seasonally to jobs in the American border states. ${ }^{146}$ Also, there are several thousand U.S. citizens of Mexican descent who hold American jobs but who actually live on the Mexican side of the line. ${ }^{147}$

Garcia y Griego, one of the principal authors of the CENIET surveys, has contested criticisms of the CENIET surveys by Census Bureau demographers. He defended the interview period of December-January because most members of the household would be home during those months, and thus it could be more accurately determined which members had remained in the United States. Moreover, he stated that CENIET interviewers generally found that household informants did not attempt to hide the facts about relatives illegally in the United States. This finding accords with the experience of other students of Mexican migration. García y Griego readily conceded that some CENIET findings, such as the fact that 405,000 legal and illegal Mexican workers were in the United States from December 1978 to January 1979, are on the low side of the migratory cycle. He emphasized, however, that the Mexican surveys also established that the average season-by-season peak for migrant workers abroad, legal or undocumented, for any year between 1974 and 1979 was $750,000,{ }^{148}$ as seen in table 18 . The 750,000 cycle figure also agrees with the Cornelius findings. According to Cornelius and García, this figure suggests the real size of a rotating migrant flow, mostly undocumented, between the United States and Mexico for the recent past period. The same figure, incidentally, has been used in some legislative proposals as the number of temporary work permits that would be needed to legalize or regularize the annual transborder flow of Mexican migrant workers. ${ }^{149}$

144. W. Cornelius \& J. Diaz Canedo, supra note 130 , at 5-7, 42-43.

145. Reichert \& Massey, Patterns of U.S. Migration from a Mexican Sending Community: A Comparison of Legal and Illegal Migrants, 13 INT'L Migration ReV. 599, 604-06 (1979).

146. D. North, The Border Crossers: People Who Live in Mexico and Work in the United STATES 106-49 (1970) (prepared for the Manpower Administration, U.S. Dep't of Labor).

147. Id. at 107-08, 121-25, 137.

148. CENIET, supra note 49 , at 122.

149. See Cornelius, Legalizing the Flow of Temporary Migrant Workers from Mexico: A Aoposal, supra note 132 , at 315 .

Various bills introduced in both houses of Congress to establish a Mexican temporary worker program 
Although some of the designers of the CENIET surveys seek to influence public policy on both sides of the border, the surveys themselves are models of academic objectivity and empirical methodology. 150 However, the "low estimates" of the CENIET studies, like the "high estimates" of other studies, naturally lend themselves to political use. Those who wish to show, for example, that there is no real immigration burden from Mexico but only a labor subsidy for the American economy, or that there is a need for a new Mexican Bracero program, can find plenty of scientific "facts" in the CENIET surveys.

Perhaps the most serious shortcoming of the CENIET household surveys is that countless households from nearly all of Mexico's thirty-two states and territories that have settled in the United States over the years would hardly have been reported. After all, there are many areas of Mexico that were not covered by the CENIET household survey where landless peasants and urban proletarians show little regret at bidding "Adios" to la madre patria. The visible evidence on the American side is simply overwhelming. Immigration, police, and educational authorities, surrounded by a rising tide of Spanish-speaking settlers, commonly estimate the number of deportable residents, including men, women, and children, in Los Angeles County alone, to run from 1,500,000 to 2,000,000, with over $75 \%$ of that number thought to be of Mexican origin. There is similar settler evidence in San Jose, El Paso, San Antonio, Houston, Dallas, Denver, Chicago, Gary, and many other locales. ${ }^{151}$ Conjectural estimates aside, community studies show that since the 1880's, when railroads first linked Mexico to the United States, undocumented or uninspected Mexican workers and their families have continuously established permanent colonias or barrios in American communities which, in turn, are steadily reinforced and expanded by extended family migration from landless Mexican villages, or, more recently, from the urban slums of Mexico. ${ }^{152}$

Nevertheless, the CENIET findings, based on such mammoth and methodical survey efforts, cannot be taken lightly. While these findings, still in the final stage of revised processing, may not accurately portray the real size of the accumulated population of deportable Mexican aliens in the United States, they undoubtedly

were influenced by Cornelius' findings. See, e.g., Remarks by Senator Schmitt on S. Res. 47, 97th Cong., 1st Sess., 127 Cong. Rec. S59-61 (daily ed. Jan. 5, 1981); see also H. Schmitt, Los Companeros: A Rational Mexican Migration Policy 14 (1980) (unpublished manuscript prepared with assistance of D. McCullough).

150. Jorge Bustamante, Director of U.S.-Mexico Border Studies at El Colegio de Mexico, spoke to this effect at an August 4, 1981 press conference before the National Press Club in Washington on "The Reagan Administration's Immigration Plan." See N.Y. Times, Aug. 5, 1981, at 18A, col. 1.

Cf. 127 CoNG. REC. S59-61 (daily ed. Jan. 5, 1981) (statement of Sen. Schmitt) (concurring in, without citing, CENIET findings).

151. Interviews with immigration officers, law enforcement authorities, social workers, and other public officials (Mar. 1-Apr. 10 \& May 1-June 15, 1981).

152. For examples of Mexican settlement studies, see R. LOUV, The MexiCAN Migration: SOUthwind (1980); P. TAYlor, Mexican Labor in THE United States (Univ. of California Publications in Economics, Vol. 6, No. 1-5, 1928-30; Vol. 7, No. 1-2, 1931-32; Vol. 12, No. 1-3, 1933-34); J. Laird, Argentine, Kansas: The Evolution of a Mexican-American Community, 1905-1940 (1975) (unpublished Univ. of Kansas Ph.D. thesis); R. Mines, Las Animas, California: A Case Study of International Network Village Migration (1980) (unpublished Univ. of California at Berkeley Ph.D. thesis); M. Nazif Shahani, Immigrant Workers in Winnemucca: A Socio-Cultural Demographic and Economic Assessment (1979) (unpublished paper available at Reno, Dep't of Anthropology, Univ. of Nevada). 
do provide a solid empirical basis for downward revision of exaggerated estimates of the rate of illegal Mexican immigration to the United States. Furthermore, they have already provided the Mexican government planners with a great stock of data about internal and external migration. Unfortunately, the CENIET surveys are not well known to American legislators and policymakers, partly due to the lack of a brief English summary of the principal findings.

\section{VIII}

\section{The 1980 Census}

\section{A. The Politics of the 1980 Census}

As the 1980 census year approached, there was still no satisfactory count, or widely accepted estimate of illegal aliens in the United States. The Carter administration found itself caught between conflicting interest groups. On the one hand, human rights and ethnic leaders, many of whom were affirmative action appointees to the administration's various advisory staffs for minority affairs, wanted the full incorporation of all minority residents, legal or otherwise, in the census count. ${ }^{153}$ Given President Carter's political commitments to minorities, and in view of the upcoming presidential election year, he could hardly ignore such pressure.

On the other hand, the administration was urged to order a special count of the illegal population. This pressure came mostly from legislators and restrictionists, some of them members of Carter's own political party, who wanted illegal residents subtracted from the census total so that this special population would count neither in political reapportionment, nor in the distribution of federal funds. Additionally, there were social scientists and demographers who thought that the Census Bureau should seize the opportunity to do a special count of illegal residents and thereby settle the perplexing question of "how many?"

After high-level consultations involving the politics of the upcoming election year, Census Bureau officials rejected a special count of illegal aliens as a constitutional, methodological, and political impossibility. First, the Census Bureau was under a sweeping constitutional mandate to count all persons in the country for purposes of apportioning political representation in the House of Representatives, according to the Constitution of 1789 , which originally mandated the decennial census. ${ }^{154}$ Following the abolition of slavery, the 14 th amendment to the Constitution (1868) reinforced the mandate: representatives shall be apportioned among the several states according to their respective numbers, "counting the whole number of persons in each state excluding Indians not taxed." 155 The Census Bureau has taken that formula quite literally except in the case of foreign embassy personnel and

153. Lindsey, Brown Power Arrives, N.Y. Times, Dec. 30, 1979, at 6D, col. 5. For President Carter's commitment to minorities, see A. Corwin, A Human Rights Dilemma, in ImMigrants-AND IMMIGRANTS: Perspectives on Mexican Labor Migration 320-46 (1978); Reinhold, Blacks and Hispanics Critical of. Census, N.Y. Times, Mar. 9, 1979, at 17A, col. 1.

154. U.S. ConST. art. I, § 2, cl. 3.

155. Id. amend. XIV, \& 2 (emphasis added). 
foreign tourists. ${ }^{156}$

Second, Census Bureau officials could not conceive of any methodology by which a reliable count of furtive illegal residents could be obtained. This view was supported by the 1978 testimony of demographers before the House Select Committee on Population that there was no accurate way one can count people who did not want to be counted, ${ }^{157}$ as well as the apparent failure of the Reyes residential survey of illegal aliens. ${ }^{158}$

Third, and perhaps most important, the Carter administration decided to direct the Census Bureau to find as many minority people as possible, particularly blacks and Hispanics, in order to remedy what were considered political undercounts of the 1970 census. Leaders of black and brown power movements saw the Voting Rights Act of 1965 as the key to further electoral gains in the twenty some states under its oversight jurisdiction. They wanted a fuller count of minority populations, legal or otherwise, within the census itself in order to broaden gains made under that act. Since the 1975 amendments to the act provided for bilingual voting in communities where census counts show that $5 \%$ or more of the adult voting population are of a foreign language heritage, the Hispanic leaders particularly had an added reason to press for a full count. ${ }^{159}$

In addition, minority leaders were interested in a full count because political counts determine how the "loaves and fishes" would be distributed. Census figures have become the vital statistics of the welfare state in more than one sense; they are used in distributing federal funds for social assistance and education programs, which, in many cases, serve as power bases for ethnic political movements. Here, the "patronage" stakes alone were enormous. By 1979 some 100 federal programs were distributing nearly $\$ 50,000,000,000$ annually on the basis of census counts. ${ }^{160}$ Much of this money was categorically marked for disadvantaged minority groups. Census data-data that included an unknown number of deportable alienswould also be used to set guidelines for equal employment opportunity hiring, job training programs, educational assistance, including bilingual education, and general revenue sharing. ${ }^{161}$

Little wonder that census advisory groups sprang up like mushrooms. These groups included: the Hispanic Advisory Panel, headed by Professor Augustan Reccio of the University of Miami; the Special Advisory Committee on Spanish Population, headed by Vilma Martinez, militant director of the Mexican-American Legal Defense Fund (MALDEF); the Black Advisory Committee, headed by

156. Some "one person-one vote" decisions of the U.S. Supreme Court relate to the controversial policy to count illegal aliens for political apportionment. Matthew v. Diaz, 426 U.S. 67 (1976); Westberry v. Sanders, 376 U.S. 1 (1964); Gray v. Sanders, 372 U.S. 368 (1963); see also 126 CoNG. Re.c. 32 (1980) (statement of Sen. Huddleston).

157. H.R. Select Comm. On Population, 95th Cong., 2d Sess., World Population: Myths and Realities 59-60 (Comm. Print 1978); see also H.R. Select Comm. on Population, 95Th Cong., 2D Sess., Legal and Illegal Immigration to the United States (Comm. Print 1978).

158. Telephone interview with Robert Warren, Researcher, U.S. Census Bureau (Oct. 6, 1981).

159. Crewdson, Houston Hearing Told of Mexican-American Fears on '80 Census, N.Y. Times, May 7, 1979, at $12 \mathrm{~B}$, col. 1.

160. Reinhold, supra note 153.

161. Crewdson, supra note 159. 
the Reverend George Riddick of Operation PUSH in Chicago; and the Special Census Inquiry Committee, set up by the United States Conference of Mayors, headed by the black mayor of Atlanta, Maynard Jackson. ${ }^{162}$ Minority leaders made no apologies for exerting influence to shape the census so that it would seek out minorities. Said Vilma Martinez, "We are trying to get our fair share of political influence and federal funds. There's nothing sinister about it."163

Given the politics of the 1980 census preparations, one can better understand why Congress gave the Census Bureau $\$ 1,000,000,000$, a sum four times larger than the cost of the 1970 census, to achieve the most complete count ever of the country's population. Furthermore, the Carter administration, in deference to the demands of the Hispanic Advisory Panel, had the Census Bureau set up a special recruitment program to hire hundreds of ethnic census-takers familiar with the neighborhoods and language differences. Since census-taking is commonly seen as a patronage job by the party in power there was some politicking involved.

Another concession to minority advisers was a multilingual media blitz that also generated about $\$ 38,000,000$ worth of "free advertising" to promote census cooperation. Minority actors, television stars, and celebrities were employed to assure minority persons that census results would be totally confidential, and to explain the revenue sharing benefits of full cooperation. ${ }^{164}$ Some state governments, such as California, invested their own money in this effort. As a satirical cartoonist put it: "Fill in your census form like a good illegal alien, thank you."165

A more remarkable concession made by the Carter administration was to permit Hispanic advisory groups to modify the census questionnaire to encourage more self-identification of Hispanics. The "Spanish question" appeared for the first time on the short form to be sent to $80 \%$ of American households: "Is this person's origin or descent Mexican-American, Mexican or Chicano, Puerto Rican, Cuban, other Spanish, not Spanish." Critics contended that the question was patently designed to inflate the Hispanic minority counts by encouraging wellassimilated people, who normally would have self-identified as white, to include themselves in the Hispanic minority count.

What more would Hispanic advisors want in an election year? The Carter administration, imprisoned by its own human rights rhetoric, fearing for its political future, and beset by its own Hispanic advisory groups, made yet another extraordinary decision. To promote a bigger count of minorities the administration ordered the U.S. Attorney General to ban all immigration searches for illegal aliens in residential communities.

On November 26, 1979, over four months prior to the starting of the census on April 1, 1980, Attorney General Benjamin Civiletti issued a directive discontinuing community area control investigations by the Immigration Service. After this directive, immigration officers could knock on a door and investigate reports of

162. Id.

163. Census Planning to Ask Racial Questions, Des Moines Reg., May 14, 1978, at 13A.

164. Jackson, Statistical Squabble, Wall St. J., Dec. 9, 1980, at 1, col. 1; Reinhold, supra note 153. Star).

165. U.S. NEwS \& WORLD REP., Apr. 14, 1980, at 7 (Oliphant cartoon reproduced from Washington 
"undocumented aliens" in places of residence only if they suspected such things as smuggling operations centered in a residence, ill-treatment or physical harm reportedly being done to undocumented aliens, fugitives misusing a residence for concealment, or Iranian students who had violated American immigration laws. ${ }^{166}$ Otherwise investigators would need search warrants, the availability of which was dependent upon detailed information about the identity of suspected illegal residents. According to Mr. Civiletti, himself a civil rights advocate, the administration's decision recognized that: "Accurate counting, so essential to the census, might be severely handicapped and full census responses chilled by a misperception of resident investigations and apprehensions . . . ."167

On March 28, 1980, Mr. Civiletti made the Carter administration's ultimate concession to Hispanic advisory groups by ordering a ban on immigration searches in places of employment unless immigration officers could show a judicial search warrant based on specific information about the identity of the illegal workers to be apprehended. Because illegal aliens use a variety of identities, such requirements meant that many work sites, like suspected residences, were no longer normally inspected by immigration officers. ${ }^{168}$ Because preliminary census results were assailed as "too low" and emerging lawsuits demanded recounts, the census bans on interior immigration control were in effect for over thirteen months. During that period immigration officers, social workers, and school teachers noted a heavier inflow of illegal alien families into American communities as "the grapevine spread the word." 169

The census ban on immigration searches and the media enticement campaign, both unprecedented in American immigration history, led a critic of the Carter administration, Senator Huddleston, a Democrat, to observe: "Illegal aliens are, in effect, being promised temporary immunity from our immigration laws and are being coached on the benefits that will accrue to their communities . . . in the form of federal funds if they come forward to be counted."170

Finally, on January 15, 1981, the ban on immigration searches at job sites was lifted. However, the ban on residential searches was left in place by the outgoing Carter administration, and has been continued by the Reagan administration. According to district directors of immigration, this residential ban, together with the chronic lack of immigration manpower, leaves American neighborhoods wide open to settlement by illegal family members. ${ }^{171}$

\section{B. The FAIR Suit and Congressional Efforts to Adjust the Census}

In November 1979 the Federation for American Immigration Reform (FAIR), an organization dedicated to immigration control and equitable immigration

166. Office of Att'y General, U.S. Dep't of Justice, (memorandum to David Crosland, Acting Commissioner of Immigration and Naturalization, from Benjamin R. Civiletti, Nov. 26, 1979).

167. Id.; see also Herman, As Census Nears, the Fears of Some Are Unrelieved, N.Y. Times, Mar. 31, 1980, at 3B, col. 2.

168. Interviews with immigration officers, supra note 151.

169. Id.

170. 126 CONG. REc. S.1984 (daily ed. Feb. 28, 1980) (statement of Sen. Huddleston).

171. Corwin, supra note 106. 
quotas, filed a motion in federal district court to stop illegal aliens from being included in the 1980 Census for purposes of reapportioning congressional electoral districts, and, implicitly, state and local districts. The Committee for Representative Government, speaking for a number of concerned organizations, joined the "FAIR suit," and so did twenty-four Congressmen and two Senators, mostly from states such as Pennsylvania and Illinois, who were concerned about losing seats to states heavily settled by illegal aliens. The defendants in the suit were the Secretary of Commerce, the Director of the Census Bureau, the Clerk of the House of Representatives, and the President of the United States. The constitutional questions raised by the FAIR suit merit special emphasis because they will probably be raised again in future census conflicts.

The plaintiffs contended that counting illegal aliens for legislative representation violated the constitutional principle of "one man, one vote." Because membership in the House of Representatives is fixed at 435, to count illegal residents would have the effect of shifting some congressional seats to states with large populations of illegal aliens, such as Texas and California, while diluting political representation in states such as Iowa and Kentucky that have a relatively constant population size. ${ }^{172}$ Moreover, plaintiffs argued that because illegal aliens would not be voting residents, certain legislators would be representing large nonvoting populations, just as Congressmen "represented" the Negro population in the period when that population was denied the vote. Plaintiffs asked for "declaratory and injunctive relief' that would require the Census Bureau to make the best effort possible to count illegal aliens separately and exclude them from the apportionment population. ${ }^{173}$ The Census Bureau responded that it was constitutionally bound by the 14th amendment to count for apportionment "the whole number of persons in each state." Furthermore, Census demographers again insisted that, in any case, an accurate method for counting illegal residents did not exist, and that any attempt at a separate count would delay the Census by several months. ${ }^{174}$

New York State and the Mexican-American Legal Defense Fund entered the suit on the side of the defendants. The intervenors argued that any attempt to count illegal aliens separately or to ascertain their resident status would "alarm the minority populations" and "inevitably trigger hostility, resentment, and refusal to cooperate" thus leading to an undercount of the total population for apportioning and revenue sharing purposes. ${ }^{175} \mathrm{MALDEF}$ contended that there was no constitutional difference between legal and illegal aliens; both are persons to be counted for political representation. ${ }^{176}$ Earlier, attorneys for the United States Department of Justice went so far as to say: "Nothing in the Constitution forbids a state from

172. Ferrell \& Slade, More Trouble for the Census, N.Y. Times, Dec. 23, 1979, at 7E, col. 4.

173. Federation for Am. Immigration Reform v. Klutznick, 486 F. Supp. 564, 568 (D.D.C. 1980).

174. Herbers, Census Bureau Bars Shifl in '80 Figures, N.Y. Times, Dec. 12, 1980, at 17A, col. 1.

175. 486 F. Supp. at $\mathbf{5 6 8 .}$

176. Mexican American Legal Defense Fund, Amicus Memorandum of Points and Authorities in Opposition to Plaintiffs' Application for Preliminary Injunction and the Plaintiffs' Motion for Summary Judgment and in Support of Defendants' Motion to Dismiss at 10 n.8. 
permitting even illegal aliens from voting for representatives"177 in state elections.

Actually the three-judge court decided the case on a procedural rather than a constitutional principle. The procedural question was whether or not the plaintiffs had established "the indispensible minimum" that "a concrete injury had been suffered," or would be suffered personally by the party seeking relief. Since no one could possibly know how many illegal aliens would be present in the census counts, nor exactly which states might gain or lose representation, the court, although admitting that a hardship may arise, decided that the plaintiffs could not demonstrate with requisite specificity where that concrete injury would fall, and so denied plaintiffs "injunctive relief." 178 Besides, said the court, "a separate head count of illegal aliens would be extremely expensive, delay the Census by as much as a year, and likely be ineffective in any case."179 The court, sounding a practical note, observed that the plaintiffs' suit came too late, "an eleventh hour challenge" just a few months before the census was to begin on April 1, 1980.!80 As critics commented,

[T] he court placed the plaintiffs in a 'Catch 22' position. A favorable ruling would have required the Census Bureau to obtain solid information on the number and distribution of illegal aliens thereby demonstrating a concrete injury. But because the information was not available beforehand the plaintiffs lacked standing to correct that injury. ${ }^{181}$

In response to the failure of the FAIR suit, Senator Walter D. Huddleston of Kentucky and others introduced Senate Bill 2366 in January 1980. That bill would have required the Secretary of Commerce and the Director of the Census. Bureau to adjust the total population figures so that illegal aliens would not be counted in tabulating population for electoral and revenue sharing purposes. The sponsors argued that the intent to grant representation to unlawful aliens could not logically be attributed to the framers of the Constitution; that the concept of illegal alien was unknown to the Founding Fathers; that there were no illegal aliens as such until the Act of March 3, 1875 excluded prostitutes and convicts. "Thus, it was only since 1875 that an individual could have been an illegal alien'." Like the FAIR plaintiffs, the sponsors of S. 2366 contended that the inclusion of illegal aliens defeated the purpose of apportionment and the principle of equal representation. ${ }^{182}$

The exclusion bill went nowhere due to the lack of an actual count of illegal aliens on which the Census Bureau could base the requested adjustments. Before giving up, however, some Senators considered a last minute plan to produce such a count by offering amnesty to a representative sample of illegal alien residents in exchange for their cooperation. ${ }^{183}$

Other legislators made a final try. In August 1980, when census results were

177. Dep't of Justice Memorandum of Points and Authorities in Support of Defendants' Motion to Dismiss the Action or in the Alternative for Summary Judgment and in Opposition to Plaintiffs' Application for a Preliminary Injunçtion at 10.

178. 486 F. Supp. at $575-77$.

179. Id. at 575 .

180. Id. at 577 .

181. 126 CONG. Rec. S1984 (daily ed. Feb. 28, 1980) (statement of Sen. Huddleston).

182. Id.

183. Telephone interview with Dan Melinck, Population Specialist, Congressional Research Service, 
widely disputed, the House of Representatives approved an amendment by Congressman Joseph McDade of Pennsylvania and others, to a routine appropriations bill, that would have forbidden the spending of further public money to count noncitizens in the census, and would have banned for apportionment purposes the use of census data containing nonvoting aliens, both legal and illegal. ${ }^{184} \mathrm{~A}$ companion amendment introduced by Senator Huddleston was approved by the Senate Appropriations Committee, but for reasons of practicality was allowed to die in the post-election session of November $1980 .{ }^{185}$ In any case, senators representing a whole state seem less concerned with reapportionment and redistricting.

\section{Census Bureau Findings: Disputed Numbers As Seen From Fort Apache}

Before considering how many residents were missed by the 1980 Census one should first consider the 1970 Census which found 189,000,000 people but by all accounts missed a substantial part of the minority populations. For example, in 1979 the Houston area Urban League estimated that the 1970 Census had missed more than 300,000 persons, mostly minorities, which had resulted in a loss of federal revenue sharing of $\$ 6,000,000$ or more annually. Similar complaints came from New York, Chicago, Detroit, and other cities. ${ }^{186}$ By the Census Bureau's own estimates, one out of seven Hispanics was missed in 1970, compared to one out of every thirteen blacks, and one of every fifty whites. ${ }^{187}$ The Bureau estimated that it missed about $2.5 \%$ of the resident population in 1970 , or about 5,300,000 people, of whom an admittedly disproportionate number were minorities. ${ }^{188}$ (Later the Bureau revised the undercount to $2.3 \%$.)

With regard to the 1980 Census, Census Director Vincent Barabba assured the Federal Government that the more elaborate efforts made to find American residents-especially minority residents-had succeeded in eliminating any substantial undercount. Obviously some illegal residents were included in the total, but no specific figure could be provided because, as had been the case with the 1970 Census, there was no question on the 1980 Census forms that could be used specifically to identify the illegal alien. When the census was completed in early summer of 1980, the "political position" of census officials was that its total count of 226,500,000 was the most complete Census count ever.

Many big city mayors did not buy the Census Bureau "line." As soon as preliminary results were known, city officials initiated court suits seeking to revise minority counts upwards. They wanted access to confidential census address regis-

The Library of Congress (Sept. 23, 1981); Telephone interview with Jeffrey Passel, Demographer, U.S. Census Bureau (Sept. 29, 1981).

184. Census Chief Asks for Appeal to Ruling that Correction Is Made for Undercount, Wall St. J., Oct. 6, 1980, at 6, col. 2; Telephone interview with Barnaby Zall, Executive Director, FAIR, Congressional Task Force (Dec. 8, 1981).

185. Jackson, Statistical Squabble, Wall St. J., Dec. 9, 1980, at 1, col. 1; Telephone interview with member of Sen. Huddleston's staff (Dec. 10, 1981).

186. Crewdson, supra note 159; Fowler, Rehearsal of Census Gets Bad Review, N. Y. Times, Mar. 31, 1979, at 24 , col. 2.

187. Crewdson, supra note 159; Reinhold, supra note 153.

188. Census Chief Asks for Appeal to Ruling that Correction /s Made for Undercount, supra note 184. 
ters to establish their case. ${ }^{189}$ On September 25, 1980, a federal judge in Detroit, Horace Gilmore, ordered the Bureau to inflate its official count of blacks and Hispanics before allowing the numbers to be used for dispensing federal aid and political reapportionment. The Bureau said that it was impossible to comply. If it did so, it would have to inflate arbitrarily every minority figure across the country. ${ }^{190}$

Mayor Edward Koch of New York City was one of those filing suit to gain higher counts. He declared the Federal Government incompetent and hinted that there was at the head of the Census Bureau a certain Barabbas, a thief (referring to Census Director Barabba). The Mayor believed that the City stood to lose $\$ 1,500,000$ in the 1980 's. A federal judge, citing independent surveys that showed an undercount of 517,000 to 650,000 for New York City and 772,000 to 905,000 for the State, ordered the Census Bureau to revise its figures upwards. ${ }^{191}$

By December 1980 there were fourteen lawsuits pending against the Census Bureau. In some of these cases, the judge ordered a restraint on the Bureau's obligation to certify the census results to the President of the United States and the Clerk of Congress on December 31, 1980. ${ }^{192}$

In the meantime, Census Bureau officials were holed up in Suitland, Maryland, in a converted warehouse that "looked more like a desolate army post than the world's leading statistical mill." Inside, the atmosphere was reportedly "pure Fort Apache." Beseiged by contempt of court charges, Census Director Barabba valiantly mounted the ramparts and declared that never in its history had the Bureau surrendered confidential information. He would go to jail first. ${ }^{193}$

Given the circumstances, it is little wonder that Census officials continued to insist that the 1980 Census was the most complete count ever. Its figure of $226,500,000$ for the total population of the United States was presented as being so close to the true population that the undercount was too small to measure. Later, Census demographers conceded an undercount but insisted that it was a mere $3,100,000$, or $1.4 \%$ of the total population, compared to $2.3 \%$ in $1970 .{ }^{194} \mathrm{Mr}$. Barabba admitted that some minority groups had been undercounted, but found such omissions were compensated for by the Bureau's ability to count some of the illegal residents. ${ }^{195}$ Finally, in spite of a ring of lawsuits, the unchanged 1980 Census results were certified and delivered to the President and the Congress on December 31, 1980. Thereupon, Mr. Barabba stepped down from the ramparts and joined private business.

For years to come the nation will have to live with the murky ethnic data of the 1980 Census. The self-identification method of counting minorities, instead of the

189. Keeping Secrets, Wall St. J., Oct. 27, 1980, at 28, col. 1.

190. Jackson, supra note 185.

191. Lubasch, Judge Mandates Census Revision, N.Y. Times, Dec. 4, 1980, at 18A.

192. Herbers, Census Bureau Bans Shift in '80 Figures, N.Y. Times, Dec. 12, 1980, at 17 A.

193. Jackson, supra note 185.

On February 22, 1982, the Supreme Court, in a decision that undercuts many census suits, unanimously held that raw census data must remain confidential and refused to review a lower court's ruling against. Detroit's challenge to the census count.

194. Consus Chief Asks for Appeal to Ruling that Correction Is Made for Undercount, supra note 184.

195. Herbers, supra note 192. 
more objective criteria of the 1970 Census which was based on place of birth and parentage, introduced a more subjective dimension. In effect, every American was asked to think ethnically or racially. Many persons of mixed ancestry, unable to fit themselves into the brief list of suggested racial or ethnic categories, listed themselves in the catch-all category of "other."196

With respect to the "Spanish question," demographers charged that the term "other Spanish" would not provide meaningful data on substantial groups such as the native Hispanics of northern New Mexico, or on immigrant groups like the Dominicans, Salvadorans, or Colombians. ${ }^{197}$ However, Census Bureau demographers believed that information about "other Spanish" could be obtained through the "long form" mailed to $20 \%$ of American households. On that form persons were asked their country of birth and whether household members born outside the United States were American citizens. But this information will not be available until long-form information can be processed. This may take many months. ${ }^{198}$ In any event, the subjective ethnic self-identifiers of the 1980 Census have made it very difficult to compare ethnic data with the 1970 Census.

The "Spanish origin" population in 1970 numbered $9,100,000$, or $4.5 \%$ of the national total. According to the 1980 figures, still considered preliminary, people of "Spanish origin" numbered $14,500,000$ or $6.4 \%$ of the national population. ${ }^{199}$ This remarkable increase may be due to a better count, the "Spanish question," high fertility rates, or higher levels of legal and illegal immigration. Of the total 1980 Hispanic population an estimated $60 \%$ were of Mexican origin, $14 \%$ Puerto Rican (not counting the Island's population), $8 \%$ Central and South American, 6\% Cuban, and $12 \%$ other Hispanic. Significantly, Mexican-origin numbers rose from $4,900,000$ in 1970 to $8,800,000$ in 1980 , a gain of $80 \% .^{200}$ By contrast, blacks numbered $22,600,000$ in 1970 , or $11.1 \%$ of the population, and $26,500,000$ in 1980 , or $11.7 \%$ of the population. ${ }^{201}$

According to Census demographers, a large percentage of Hispanics could have misunderstood the Census questionnaire. The first question on the short form had listings for whites, blacks, and twelve Asian, Indian, Native American, and Pacific Island groups, as well as "other." About $55.6 \%$ of the Spanish origin persons, or $8,100,000$ reported as "white," but it is noteworthy that $40 \%$, or $5,800,000$, did not report a specific race, but chose "other," with smaller numbers reporting black (some Dominicans or Puerto Ricans, for example), American Indian (for example, Navajos with spanish surname), or Asian and Pacific

196. Reinhold, 1980 Census Shows 17\% Growth of Blacks Surpassed Rise for U.S., N.Y. Times, Feb. 24, 1981 , at 1 , col. 1 .

197. Bureau of the Census, U.S. Dep't of Commerce, 1980 Census Population Totals for Racial and Spanish Origin Groups 1 (Public Information Release, CB 81-32, Feb. 23, 1981); cf. Reinhold, 'Others' (Among Others) Play Havoc With Census, N.Y. Times, Oct. 11, 1981, at 8E, col. 3.

198. Telephone interview with Dan Melinck, supra note 183; Telephone interview with Jeffrey Passel, supra note 183.

199. Herbers, Census Shows Minority Groups Gaining in Big Cities, N.Y. Times, Apr. 16, 1981, at 1, col. 1.

200. Congressional Hispanic Caucus, Hispanics in the United States, AvanCE, June 1982, at 3.

201. Bureau of the Census, U.S. Dep't of Commerce, supra note 197. 
Islanders (Filipinos with Spanish surname, for instance). ${ }^{202}$ In any case, the "other" population grew remarkably from about 500,000 in 1970 to $6,800,000$ in 1980, apparently because many Hispanics, including an unknown number of illegals, picked that category, rather than identify themselves as Salvadorans, Colombians, Peruvians, Dominicans, or other Latin nationality. ${ }^{203}$

According to 1980 Census findings, Hispanics, who are commonly thought to compose up to $75 \%$ of all illegal residents, had a much younger median age, 23.2, compared to 24.9 for blacks, and 30 for the population as a whole. Of the $14,600,000$ Hispanics counted, $63 \%$ were under the age of 30 . Such age data seems to give some clues as to the demographic impact of illegal immigration. For instance, there were more Hispanic men than women in the age groups 20 to 24 and 25 to 29, "an unusual demographic pattern" according to demographer Bryant Robey. ${ }^{204}$ Another clue was the presence of $50 \%$ more Hispanic males in the 20 to 34 age group than in 1970. Yet the differences in growth rates between Hispanic men and women disappeared at age 40 . This type of data tends to confirm the common visual observation that illegal Hispanic immigration is dominated by young men. ${ }^{205}$

No matter how they classified themselves, Hispanics obviously made extraordinary gains in the 1980 Census. Nevertheless, those Hispanic leaders who want Hispanics to overtake blacks as America's number one minority, had hoped for a count of 20,000,000 or more, while some Mexican Americans had anticipated a count of $10,000,000$ or $11,000,000$ for people of Mexican origin. ${ }^{206}$ Census Bureau demographers explain that Hispanic "undercounts" as perceived by Hispanic leaders, may be in part due to some Hispanic leaders, rejecting any special racial or ethnic category and identifying themselves as "white." But, more importantly, many illegal Hispanic residents simply did not report under any category. ${ }^{207}$

\section{Illegal Aliens in the Census: How Many?}

The stubborn fact is that there were no questions on either the short or long census form from which an alien's legal status could be determined. Thus any estimate of the illegal resident aliens counted by the census would have to be based on residual techniques which always involve questionable assumptions. ${ }^{208}$ In a supplemental affidavit to the FAIR suit, Lance Tarrance, a population survey expert, expressed the belief that the Bureau could obtain a residual figure on illegal residents without confronting delays and added costs from long-form data.

202. Telephone interview with Dan Melinck, supra note 198; Telephone interview with Jeffrey Passel, supra note 198 .

203. Reinhold, supra note 197.

204. Robey, Age in America: 1980 Census Trends, Am. DemograPhics, July/Aug. 1981, at 16.

205. Id.

206. Interview with Herman Baca, Director, Committee on Chicano Rights, Inc., National City, Cal. (May 11, 1981); Interview with Francisco Garaza, Congressional Liaison, National Council of La Raza (Aug. 6, 1981); Interview with Rose Marie Salazar, Migration Specialist, Hispanic Secretariat, U.S. Catholic Conference (June 18, 1981).

207. Telephone interview with Dan Melinck, supra note 198.

208. Telephone interview with Dan Melinck, supra note 198; Telephone interview with Jeffrey Passel, supra note 198 . 
The long form which asked about citizenship status was sent to one-fifth of American households-some 17,000,000 nationwide. Assuming that family members were fully reported, the Bureau could statistically estimate from that data persons born outside the United States who were not naturalized citizens. It could then compare this estimate with a figure based on immigration data for legal aliens. Subtracting the second figure from the first would lead to an estimated number of illegal aliens counted by the Census. ${ }^{209}$ However, the INS does not have accurate exit records for immigrants; and further, information from the long forms is still being processed. It may be months before any such estimate can be determined from this source.

Census Bureau demographers have been using other residual techniques in the meantime in order to determine the size of the illegal population within the census count. They have been giving special attention to the Hispanics because this category apparently contains the greatest number of illegal residents. The reported number of Hispanics increased 5,500,000 between 1970 and 1980. Of this increase census demographers figure only $1,800,000$ can be attributed to natural increase. $^{210}$ Another 1,200,000 can be attributed to the net inflow of legal Hispanic immigrants during the decade. ${ }^{211}$ That would leave 2,500,000 Hispanics to be accounted for. However, this entire number would not necessarily represent the number of illegal aliens. It could be the result of better census coverage, or the result of the "Spanish question" that, in some cases, added persons normally thought of as "non-Hispanic."212 For instance, in 1970 some 2,400 Filipinos with Spanish surnames labeled themselves Hispanics; in 1980 some 200,000 did so. Also, more American Indians in the Southwest with Spanish surnames identified themselves as Hispanics in $1980 .^{213}$ Here one reaches a methodological impasse.

Census Bureau demographers are also quietly at work on revising the number of U.S. residents, including illegal aliens, that may have been missed by the 1980 Census. The revision involves analytic and matching techniques that include U.S. birth and death rates, immigration and emigration data, and sample survey data from the current population surveys and the 1980 Census, such as those presently being used by Robert Warren and Jeffrey Passel. ${ }^{214}$ The possible undercount has been raised hypothetically to $2 \%$ of the total population of $226,500,000$, or approximately 4,500,000. But in the opinion of census experts, there is no known method for determining what part of that tentative undercount estimate could be illegal aliens. ${ }^{215}$

209. Federation for Am. Immigration Reform v. Klutznick, 486 F. Supp. 564, 575 (D.D.C. 1980) (quoting affidavit of Lance Tarrance, regarding counting of illegal aliens for political representation and federal-revenue sharing).

210. Robey, supra note 204.

211. Immigration and Naturalization Service, Dep't of Justice, Annual Report Table 8 (1980); Interviews with Hispanic leaders, supra note 206.

212. Robey, supra note 204.

213. Robey, supra note 204 , at $16,18$.

214. See supra text accompanying note 58.

215. Telephone interview with Dan Melinck, supra note 183; Telephone interview with Jeffrey Passel, supro note 183 . 


\section{IX}

\section{Time fOR Legislative ACtion?}

What, if anything, should be done about illegal alien residents? In its final report issued in March 1981, SCIRP recommended a one-time generous amnesty program for persons who had illegally settled in the United States prior to January $1,1980 .{ }^{216}$ In proposing other generous reforms the Commission was influenced by the conservative estimate of $3,500,000$ to $6,000,000$ illegals provided by Census Bureau demographers. ${ }^{217}$ The Inter-Agency Task Force, appointed in February 1981 by a newly elected Reagan administration, and under the direction of Attorney General William French Smith, proposed a similar amnesty arrangement using the same cut-off date and the same speculative estimate of illegal aliens. ${ }^{218}$ Under the administration's plan, however, applicants for permanent resident alien status would have to prove continuous residence in the United States for a period of ten years, and during that time, as "renewable-term entrants," they could not bring in spouses, children, or other dependents. ${ }^{219}$

Many immigration experts, legislators, and INS officials consider the estimate of 3,500,000 to $6,000,000$ to be too low and outdated. ${ }^{220}$ However, the Reagan administration, which incidentally is not clear on whether the estimate refers to an illegal work force, or covers family dependents as well, is not keenly interested in higher estimates no matter how plausible. Higher estimates would justify demands for increased funding for the helpless Immigration Service in a period of fiscal restraint for all government agencies, and could result in even greater public opposition to the administration's proposals for mass legalization of foreign workers and a new temporary labor program for Mexican nationals. With unemployment at crisis level and state and local governments expected to take on

216. SCIRP FINAL REPORT, supra note 2, at 72-85.

217. Among the Commission's recommendations were the following: an amnesty program that would offer legal resident alien status to aliens otherwise admissable who had entered before January 1, 1980; a raise in the annual ceiling on immigration from 290,000 to 350,000 , plus an additional 100,000 visas each year for five years in order to clear backlogs of visa applicants many of whom were already residing illegally in the United States. And, for the same reason, more immediate relatives of permanent resident aliens would be allowed to enter under a special worldwide ceiling to be established for that purpose. SCIRP FINAL REPORT, supra note 2, at 47-48.

218. The Task Force proposed a limited amnesty for illegal workers, but not family members. Apparently the Task Force assumed that most of the estimated illegals were in the labor force. To prevent any disruption in certain sectors of the American economy the amnestied alien would enjoy a "renewable entrant status," which paradoxically would allow the "entrant" to change employers virtually at will. After a proven ten-year residence, the entrant could apply for a permanent visa.

To help further with the problem of "absorbing" illegal aliens and visa backlogs, Mexico and Canada would be given a special immigration ceiling of 40,000 per year (not counting immediate relatives), compared to 20,000 for all other countries. The unused Canadian visas would be available to Mexican applicants. Additionally, the Reagan administration would have established an experimental two-year temporary worker program to help legalize 50,000 Mexican seasonal workers. Presumably the program could have been expanded to cover several hundred thousand perennial transborder migrants.

219. Office of Att'y General, U.S. Dep't of Justice, Omnibus Immigration Control Act, Title I: Temporary Resident Status for Illegal Aliens (submitted to the President and Congress, Oct. 20, 1981).

220. Interviews with immigration officers, supra note 151; see also Knowing Employment of Illegal Immigrants, 1981: Hearings Before the Subcomm. on Immigration and Refugee Policy of the Senate Comm. on the Judiciary, 97th Cong., 1st Sess. 194-98, 218-22 (1981) (statement of Vernon M. Briggs, Cornell Univ. \& David S. North, Director, Center for Labor and Migration Studies). 
increasing social and educational costs related to poverty-stricken immigrants and refugees from the Third World, the administration was not about to raise the illegal alien count. ${ }^{221}$

Congress is presently confronted with a number of bills containing amnesty provisions, but federal legislators still have no firm residential data on the size, the ethnic character, or the flow of the illegal alien population. As the U.S. Comptroller General advised Congress:

Given the above situation, legislators will have to, in a sense, make their own estimate of the undocumented alien population. Legislators may wish to weigh the desirability and feasibility of any proposed actions on both a "best" and "worst" case basis. What may seem right premised on an undocumented alien population of 1 or 2 million could be inappropriate if this population was actually 10 million or more. ${ }^{222}$

Meanwhile, in the face of the great uncertainty about alien numbers and the American economy, a major bipartisan bill, introduced on March 17, 1982, called for a sweeping legalization program. The Immigration Reform and Control Act of 1982, introduced by Senator Alan K. Simpson and Congressman Romano Mazzoli, ${ }^{223}$ makes illegal aliens who have resided continuously in the United States prior to January 1, 1978, and who have no serious criminal record, eligible for permanent immigrant status, for social assistance, and for the right to petition for the admission of relatives. After five years they become eligible to apply for naturalization and the right to bring in immediate relatives with no wait. Illegal aliens who entered between January 1, 1978 and January 1, 1980, may apply for "Temporary Resident" status which carries no social entitlements except health care, but which provides the legal right to seek any kind of employment. After two years they become eligible to apply for permanent residence with entitlements if they can demonstrate a minimal knowledge of English. Aliens who entered after January 1, 1980 would be considered "deportable." There are also accompanying provisions aimed at future immigration control included in the bill.

In considering amnesty proposals Congress must consider the question of how many aliens might be legalized under a given cut-off date, such as 1980 or 1982 . It is equally important to consider the potential multiplier effects: How many mil-

221. Another fitting comment on the politics of numbers is that the Governor of Texas, Bill Clements, decided to attempt his own residential survey of illegal Mexican aliens in Texas. He planned to use the figures in the Supreme Court case involving undocumented children in Texas public schools and in an attempt to convince the federal government to institute a "guest worker" program for border migration control according to Memorandum of October 23, 1981, from the State of Texas Office of State-Federal Relations, Wash., D.C.; Hearings on H-2 Workers and Non-Immigrants Before the Subcomm. on Immigration and Refugee Policy of the Senate Comm. on the Judiciary, 97TH CoNG., 1ST. SESs. (1981) (Gov. Clements testifying).

222. U.S. Comptroller General, Number of Undocumented Aliens Residing in The UNITED STATES UNKNOWN: REPORT 4 (1981).

223. Among other things the Simpson/Mazzoli bill, Immigration, Reform and Control Act of 1982, S. 2222, H.R. 6514, 97th Cong., 2d Sess. (1982); would establish the following: a fixed annual cap on immigrant admissions of 425,000 , but not including refugees; civil sanctions for employers of illegal aliens; a new identification system for all job applicants; stiff penalties for persons engaged in bringing in aliens not authorized to enter the United States; a higher immigration ceiling of 40,000 for Mexico and the same for Canada, with an understanding that unused Canadian visas would go to Mexican applicants, while all other countries would be limited to 20,000; expedited procedures for handling asylum and deportation cases, and for bringing in temporary foreign workers mainly for agricultural employment. The bill was reintroduced in 1983 by Senator Simpson and Congressman Mazzoli. 
lions of immigrant visa petitions would be generated by legalized aliens? How many visa petitioners would come in anyway as tourists and visitors while waiting for restricted visa numbers? How many legalized aliens and their dependents would go on social assistance and minority entitlements programs? Taken together such questions pose an amnesty dilemma.

Meanwhile, as 1983 opened a persistent economic recession was sending unemployment rates to well over $10 \%$ of the national labor force. The Immigration Service was expected to protect jobs for Americans, but received little help from a budget-cutting administration. Until some action is taken, illegal entrants and overstay visitors will continue to enter the country almost at will through hurried visa services, through poorly inspected airport terminals, and through poorly guarded land borders. ${ }^{224}$ It is clear that the numbers game will be around for a long time to come.

224. An understaffed and underfunded Immigration Service, far behind in processing papers, has no idea how many of the millions of foreign visitors (who entered on I-94 forms) actually leave the United States. See, e.g., 20 Million Lost in U.S. Maze, Chicago Trib., Nov. 23, 1981, at 1, col. 1.; see also supra text accompanying notes 25,34 . 


\section{APPENDIX A}

Deportable Aliens Located, Aliens Deported, and Aliens REQUiRed to DePART Years Ended June 30, 1892-1976, JULY-SEPTEMBER 1976 AND YEARS ENDED

SEPTEMBER 30, 1977-1982

\begin{tabular}{|c|c|c|c|}
\hline PERIOD & $\begin{array}{c}\text { Deportable } \\
\text { Aliens Located } \\
\text { (Arrested) }\end{array}$ & $\begin{array}{l}\text { Aliens Formally } \\
\text { Deported }\end{array}$ & $\begin{array}{c}\text { Aliens required } \\
\text { to Depart }{ }^{2}\end{array}$ \\
\hline $1892-1978 \ldots \ldots \ldots$ & $13,195,175$ & 777,483 & $12,416,140$ \\
\hline $1892-1900 \ldots \ldots \ldots$ & - & 3,127 & - \\
\hline $1901-1910 \ldots \ldots$ & - & 11,558 & - \\
\hline $1911-1920 \ldots \ldots \ldots$ & - & 27,912 & - \\
\hline $1921-1930 \ldots \ldots$ & 128,484 & 92,157 & 72,233 \\
\hline $1931-1940 \ldots \ldots \ldots$ & 147,457 & 117,086 & 93,330 \\
\hline $1941-1950 \ldots \ldots$ & $1,377,210$ & 110,849 & $1,470,925$ \\
\hline $1941 \ldots$ & 11,294 & 4,407 & 6,531 \\
\hline $1942 \ldots \ldots \ldots \ldots$ & 11,784 & 3,709 & 6,904 \\
\hline $1943 \ldots \ldots \ldots \ldots$ & 11,175 & 4,207 & 11,947 \\
\hline $1944 \ldots \ldots \ldots \ldots$ & 31,174 & 7,179 & 32,270 \\
\hline 1945 & 69,164 & 11,270 & 69,490 \\
\hline $1946 \ldots \ldots \ldots$ & 99,591 & 14,375 & 101,945 \\
\hline $1947 \ldots \ldots \ldots$ & 193,657 & 18,663 & 195,880 \\
\hline $1948 \ldots \ldots \ldots \ldots$ & 192,779 & 20,371 & 197,184 \\
\hline $1949 \ldots \ldots \ldots$ & 288,253 & 20,040 & 276,297 \\
\hline $1950 \ldots \ldots \ldots$ & 468,339 & 6,628 & 572,477 \\
\hline $1951-1960 \ldots \ldots$ & $3,598,949$ & 129,887 & $3,883,660$ \\
\hline $1951 \ldots \ldots \ldots$ & 509,040 & 13,544 & 673,169 \\
\hline 1952 & $543,535^{3}$ & 20,181 & 703,778 \\
\hline $1953 \ldots \ldots \ldots$ & 885,587 & 19,845 & 885,391 \\
\hline $1954 \ldots \ldots \ldots$ & $1,089,583$ & 26,951 & $1,074,277$ \\
\hline $1955 \ldots \ldots \ldots$ & 254,096 & 15,028 & 232,769 \\
\hline $1956 \ldots \ldots \ldots$ & 87,696 & 7,297 & 80,891 \\
\hline $1957 \ldots \ldots \ldots$ & 59,918 & 5,082 & 63,379 \\
\hline $1958 \ldots \ldots \ldots$ & 53,474 & 7,142 & 60,600 \\
\hline $1959 \ldots \ldots \ldots$ & 45,336 & 7,988 & 56,610 \\
\hline $1960 \ldots \ldots \ldots$ & 70,684 & 6,829 & 52,796 \\
\hline $1961-1970 \ldots \ldots$ & $1,608,356$ & 96,374 & $1,334,528$ \\
\hline$\ldots \ldots \ldots$ & 88,823 & 7,438 & 52,383 \\
\hline $1962 \ldots \ldots \ldots \ldots$ & 92,758 & 7,637 & 54,164 \\
\hline $1963 \ldots \ldots \ldots$ & 88,712 & 7,454 & 69,392 \\
\hline 1964 & 86,597 & 8,746 & 73,042 \\
\hline$\ldots \ldots \ldots$ & 110,371 & 10,143 & 95,263 \\
\hline $1966 \ldots \ldots \ldots$ & 138,520 & 9,168 & 123,683 \\
\hline $1967 \ldots \ldots \ldots$ & 161,608 & 9,260 & 142,343 \\
\hline $1968 \ldots \ldots \ldots$ & 212,057 & 9,130 & 179,952 \\
\hline $1969 \ldots \ldots \ldots$ & 283,557 & 10,505 & 240,958 \\
\hline $1970 \ldots \ldots \ldots$ & 345,353 & 16,893 & 303,348 \\
\hline $1971-1980 \ldots \ldots$ & $8,321,498$ & 231,694 & $7,246,812$ \\
\hline $1971 \ldots \ldots \ldots$ & 420,126 & 17,639 & 370,074 \\
\hline $1972 \ldots \ldots \ldots$ & 505,949 & 16,266 & 450,927 \\
\hline $1973 \ldots \ldots \ldots$ & 655,968 & 16,842 & 568,005 \\
\hline
\end{tabular}




\begin{tabular}{lrrr}
$1974 \ldots \ldots \ldots \ldots$ & 788,145 & 18,824 & 718,740 \\
$1975 \ldots \ldots \ldots \ldots$ & 766,600 & 23,438 & 655,814 \\
$1976 \ldots \ldots \ldots \ldots$ & 875,915 & 27,998 & 765,094 \\
$1976 \ldots Q \ldots \ldots \ldots$ & 221,824 & 8,927 & 190,280 \\
$1977 \ldots \ldots \ldots \ldots$ & $1,042,215$ & 30,228 & 867,015 \\
$1978 \ldots \ldots \ldots \ldots$ & $1,057,977$ & 28,371 & 975,515 \\
$1979 \ldots \ldots \ldots \ldots$ & $1,076,418$ & 25,888 & 966,137 \\
$1980 \ldots \ldots \ldots \ldots$ & 910,361 & $17,273^{4}$ & 719,211 \\
$1981 \ldots \ldots \ldots \ldots$ & 975,780 & $16,654^{4}$ & 820,946 \\
$1982 \ldots \ldots \ldots$ & 962,687 & 14,154 & 809,577 \\
\hline
\end{tabular}

1. Aliens apprehended first recorded in 1925. Prior to 1960, represents total aliens actually apprehended. Since 1960, figures are for total deportable aliens located (arrested), including nonwillful crewmen violators.

2. Aliens required to depart as "non-penalty voluntary departures", first recorded in 1927.

3. Adjustment made for 1952 .

4. Drop due to personnel shortages and special details for Cuban/Haitan entrants. TQ equals 3 months. Fiscal year changed from June 30, to September 30.

1980 drop in apprehensions due to ban on certain immigration control operations during the Census period, November 26, 1979 to January 15, 1981. Drop in 1982 partly due to high U.S. unemployment rates of around $10 \%$.

Note: In recent years about $87 \%$ to $90 \%$ of apprehensions have been Mexican nationals, mainly because the Immigration Service concentrates enforcement efforts more on the states bordering Mexico. Arrest figures for Mexican nationals will probably rise sharply in fiscal 1983 due to Mexico's severe financial crisis.

Source: Immigration and Naturalization Service, U.S. Dep'T or Justice, Annual Report Table 30 (1979); Data from Statistical Office, Central Office, INS. 


\section{APPENDIX B}

\section{INS STAFFING LEVELS}

The outgoing Carter administration, which had done little about immigration and refugee control, recommended an Immigration Service budget of $\$ 385,000,000$ for fiscal 1982 , compared to a working budget of $\$ 371,500,000$ for fiscal 1981. Given the $10 \%$ annual rate of inflation, the proposed increase was actually a substantial cut in INS resources and personnel.

When the Reagan team took over early in 1981, it was largely ignorant about the seriousness of immigration affairs. Before coming to Washington, administration study groups had labored on a range of conservative policy reforms but not specifically on immigration and refugee problems. The new administration, dedicated to reducing the size of the federal bureaucracy, was determined to spare no federal agency from budget cuts. At first, the President's Office of Management and Budget (OMB) slashed $\$ 21,600,000$ and 973 positions from the INS budget as proposed by the Carter administration! That would have left the INS with a fiscal 1982 budget of $\$ 363,400,000$ and a permanent staffing level of only 9,531 positions-approximately its 1977 level of budget and personnel.

The Reagan administration soon learned, however, that it had inherited a colossal immigration and refugee mess, plus a formidable list of reform recommendations from the distinguished Select Commission on Immigration and Refugee Policy. The response of the new administration was to set up an inter-agency task force, under Attorney General William French Smith, to study policy responses. Although Mr. Smith came to Washington innocent about immigration enforcement needs, after listening to budget proposals from his own immigration agency and confronting embarrasing questions from Congress, he urged the White House to give higher priority to immigration and refugee control problems, particularly in south Florida. At the same time, the Senate and House appropriation committees, which were more aware of public demands for migration control than the OMB, worked not only to restore the Immigration Service cuts proposed by the Reagan administration, but to substantially increase funding and personnel over the 1981 level.

As a result the INS budget authorization of $\$ 428,500,000$ for fiscal 1982 was $\$ 65,000,000$ over what the administration had first proposed. The funding increase was accompanied by staff increase of 1,073 permanent positions over the administration's first proposal, giving the INS a total staff of 10,604 for fiscal 1982, plus about 852 "work years" for nonpermanent employees and added costs related to permanent employees.

In view of the fiscal restraints the administration put on nearly all government agencies (except the Pentagon) the final fiscal 1982 budget for the INS represented a remarkable concession to the needs of the Immigration Service. Unfortunately, the 1982 budget distribution actually left less funding available for enforcement at major points of illegal entry and for keeping illegal aliens out of the American job market. Under heavy political pressure to "save Florida," the administration allo= cated over $\$ 40,000,000$ of the 1982 INS budget increase to cover costly detention programs and case-by-case asylum hearings related mostly to Cuban refugee "mis- 
fits" and illegal Haitian "boat people." This allocation was made even though the Caribbean refugee problem was numerically insignificant compared to the massive number of illegal and mala fide entries on the southern land border and through superficially inspected airports.

The INS also lost some enforcement positions in 1982. In spite of a critical shortage of inspectors and investigators, the administration reduced these positions by 202 and 190, respectively, leaving a token force of about 1350 field inspectors to cover some 430 ports-of-entry (many of them open twenty-four hours a day, seven days a week) and 725 investigators for interior immigration control throughout the United States. By contrast, in 1976, when the INS was already pathetically undermanned, there were in the field around 1,400 inspectors and over 800 investigators. Personnel levels in both Adjudications and Status Verifications were also cut. In Adjudications, where staff was needed to process a huge backlog of claims and petitions, 195 positions were cut. In Status Verifications, where staff members winnow out fraudulent documents and statements, 91 positions were lost. This left staff totals of 575 and 162, respectively, for fiscal 1982.

On the other hand, the Border Patrol was slightly increased in fiscal 1982 by 54 positions above the congressional authorization, giving it a total authorized force of 2,694. Not all of those positions may be funded, however. Currently, under normal operating procedures, the Border Patrol can allocate only about 450 men to any given eight-hour shift on the Mexican border. That border stretches some 1,900 miles. Rather than affording some slight improvement to the problems of border coverage, this small increase in staff size was more than offset by the extensive use of border patrolmen as detention officers in centers where Haitians are held pending review of asylum claims. Relatedly, the number of detention and deportation officers was enlarged by 232 , but again, this was done mainly to allow the detention of Haitian "boat refugees" in order to stem any future Caribbean "refugee" flows.

The INS continuing resolution for fiscal 1983 was $\$ 495.7$ million, including the anticipated pay raise, with a total authorized personnel of 10,483, plus about 671 "work years" for nonpermanent employees, and added costs such as overtime. At the beginning of fiscal 1983, the total on-duty enforcement personnel was as follows: 1355 inspectors, 888 investigators, and 2504 border patrol officers. In weighing the total amount of the 1983 budget one should bear in mind that, again, a large part of the same, $\$ 27.2$ million, was destined for the reception, processing, and care of Cuban and Haitian entrants.

Thus far, the Reagan administration has concentrated mostly on a refugee deterrent policy for south Florida while it hoped for congressional approval of its Omnibus Immigration Control Act submitted to Congress on October 20, 1981. This act proposed civil sanctions for employers who hire three or more illegal aliens and other preventive measures. Meanwhile, however, the ability of the Immigration Service to apply existing preventive-measures to illegal entrants has actually been further diminished by the Reagan administration. Further, the administration has made no provision to add public service personnel to the INS. Consequently, it is expected that the "service mess" at most immigration offices 
will continue. More serious, the administration, in 1982 and 1983, was caught undermanned and flatfooted by an exodus over the southwestern border of undocumented Mexican naturals fleeing Mexico's current financial crisis.

- Sources: Department of JUStice ApPropriations AUthorization Act, Fiscal Year 1982, H.R. REP. No. 105, 97th Cong., 1st Sess., 20-21 (1981); Chaze \& Migdail, Invasion from Mexico-It Just Keeps Growing, U.S News \& WOR LD ReP., Mar. 7, 1983, at 37, 37-44; Kelly, The Great American Immigration Nightmare, U.S. NEWS AND WORLD REP., June 22, 1981, at 27, 27-32; Pear, It's Time for Immigration Law Reform-Or Is It?, N.Y. Times, Jan. 3, 1982 (contains a handy resume of the Administration's proposals for immigration control and the prospects for congressional approval); Letter from Michael G. Harpold, President, National Immigration and Naturalization Service Council of the American Federation of Government Employees, to Congressman Romano Mazzoli, Chairman, House Subcommittee on Immigration, Refugees, and International Law (Nov. 4, 1981); Memorandum from Peter Regis, Legislative Assistant, to Chairman Mazzoli on Summary of Fiscal Year 1982 Revised Budget Request (Nov. 2, 1981); Data from INS Budget Office, Central Office (Jan. 21-22, 1982; Feb. 1983). 
INS: Staffing Levels and Ceilings Since Fiscal Year 1977

Authorized full-time permanent positions

Actual end of year Full-time permanent

Other than full-time permanent

\section{Total}

OMB ceiling end of year

Full-time permanent

Other than full-time permanent

Total

\begin{tabular}{|c|c|c|c|c|c|c|}
\hline \multicolumn{7}{|c|}{ Fiscal Year } \\
\hline 1977 & $\underline{1978}$ & 1979 & $\underline{1980}$ & 1981 & $\underline{1982}$ & $\underline{1983}$ \\
\hline$\underline{9,472}$ & 10,071 & b $\underline{10,997}$ & c 10,943 & $\mathrm{~d}$ & 10,619 & ${ }^{h} \underline{10,483}$ \\
\hline 8,812 & 9,859 & 9,695 & 9,993 & a $\underline{9,786}$ & $\underline{9,957}$ & $\underline{9,950}$ \\
\hline r & $f$ & $f$ & $\mathrm{f}$ & 81,545 & 1,391 & ${ }^{\mathrm{i}} \underline{1,805}$ \\
\hline- & - & - & - & 11,331 & 11,348 & 11,755 \\
\hline 9,046 & 9,827 & 10,110 & 10,445 & 9,739 & 9,964 & $j$ \\
\hline 731 & 731 & 678 & 729 & 682 & 696 & $\mathbf{j}$ \\
\hline$\underline{9,777}$ & 10,558 & 10,788 & 11,174 & $\underline{10,423}$ & 10,660 & \\
\hline
\end{tabular}

actual on-board strength as of April 4, 1981.

b495 positions were not allocated in FY 1979 in anticipation of an equivalent cut in FY 1980.

c227 positions were not allocated in FY 1980 in anticipation of an equivalent cut in FY 1981.

d 170 positions were not allocated in FY 1981. The \$6 million saved, according to INS, was used to fund the pay raise.

ePositions are for the pay period nearest the end of the fiscal year for which data was available.

Data not readily available.

gOn-duty as of April 18, 1981.

h Judicial review program (136 positions) dropped.

iAs of 12/25/82.

jData no longer available due to a change in report format.

Source: Letter from Clifford I. Gould, Director of U.S. General Accounting Office, to Congresswoman Geraldine A. Ferraro, Chairwoman, Subcommittee on Human Resources (Aug. 20, 1981). 


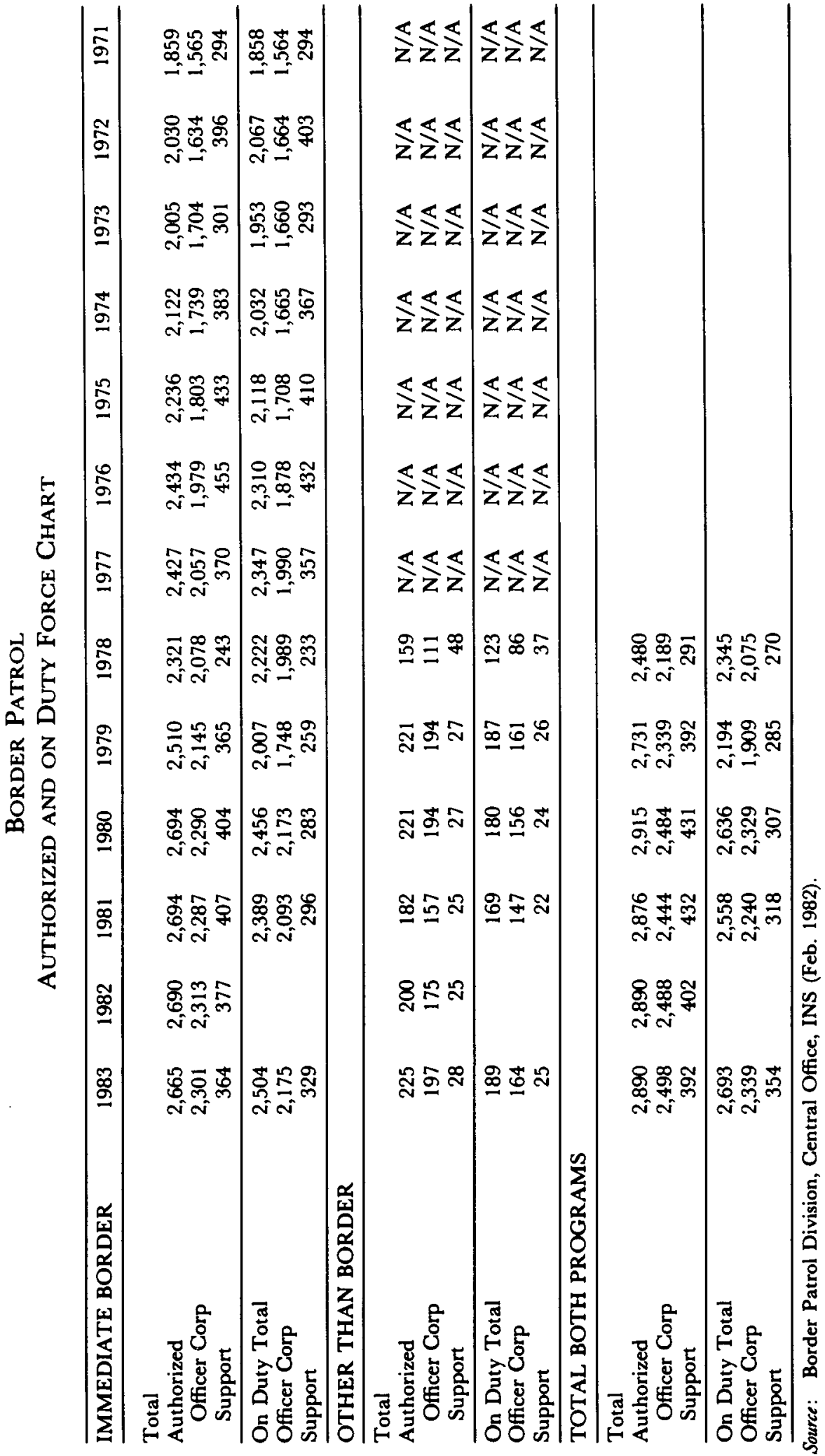




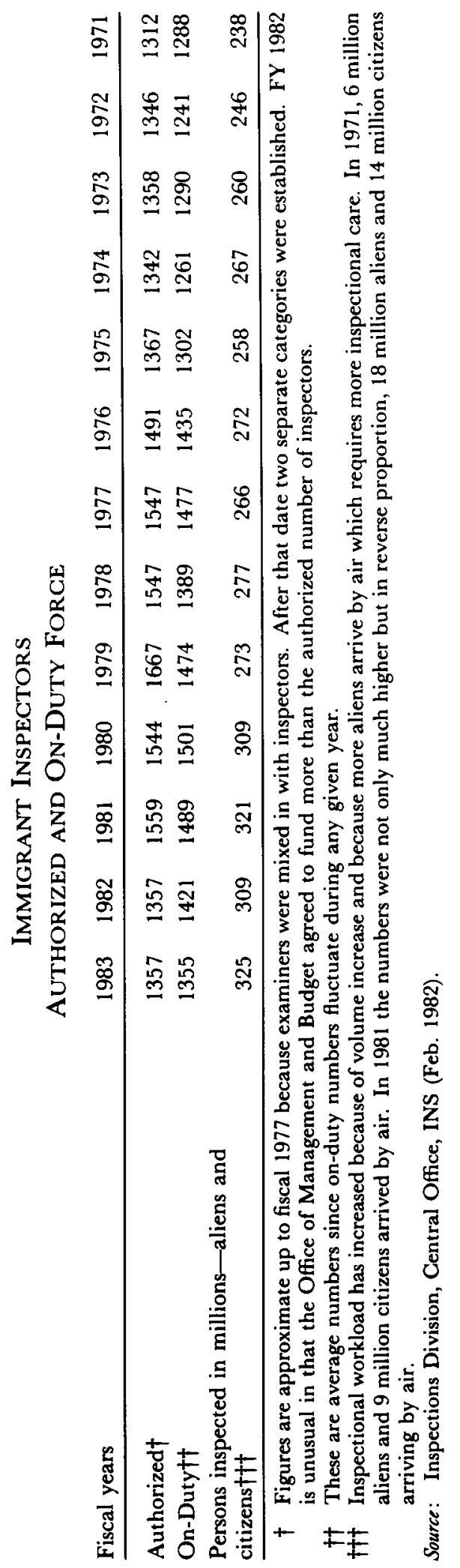




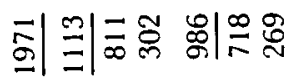

$\overleftrightarrow{z}$

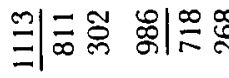

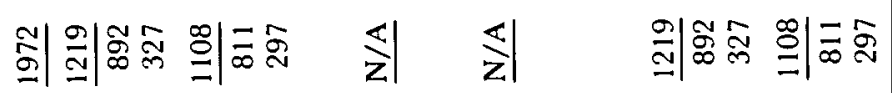

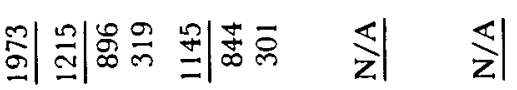

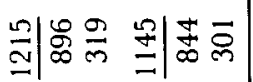

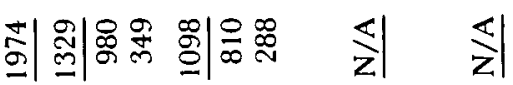

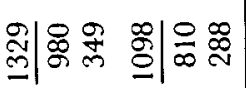

芯

文至

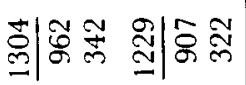

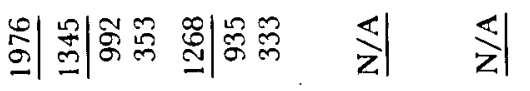

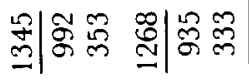

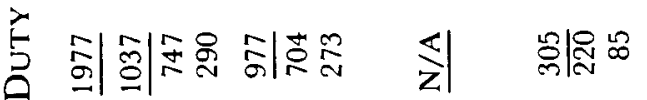

:

z

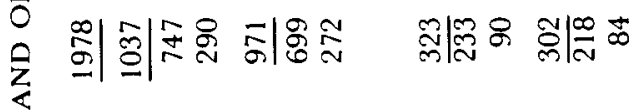

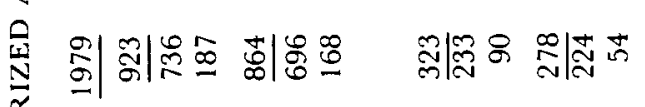

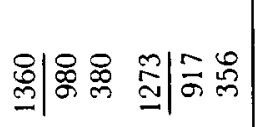

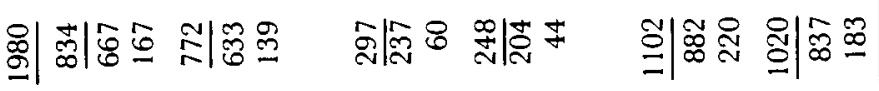

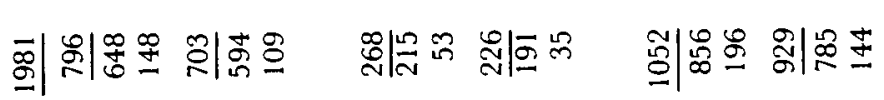

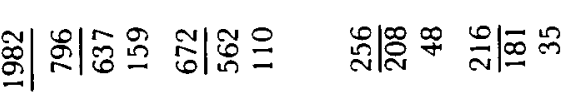

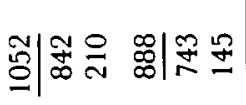

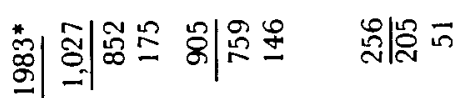

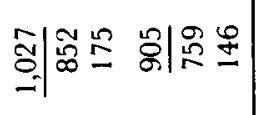

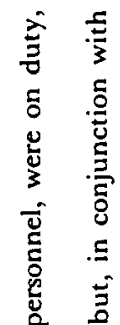

范

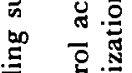

政 政 的施 要 范范

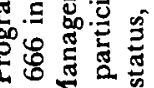

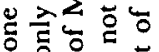
웜 政

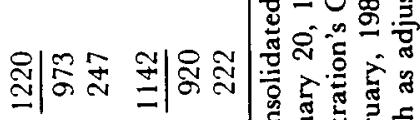

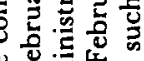

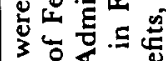
5 र

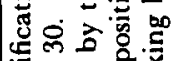

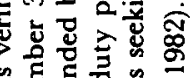
胥

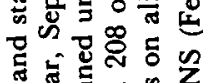
E

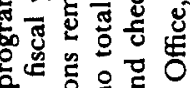

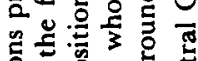

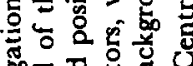

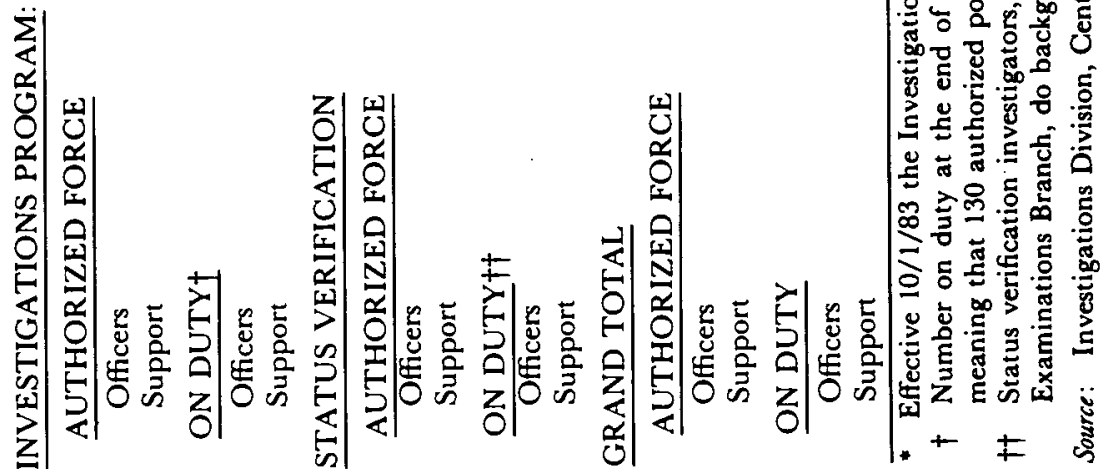




\section{APPENDIX $\mathrm{C}$}

American Consular Positions and Caseloads 1975, 1980

1975

Consular positions

(Foreign national Positions: 1,593$)^{*}$

1980 Consular positions

(Foreign national positions: 1,843 )

1975 Immigrant visas issued:

Immigrant visas refused:

CASELOAD: Subtotal

Nonimmigrant visas issued:

Nonimmigrant visas refused:

CASELOAD: Subtotal
563

696

304,000

91,000

395,000

$3,330,00$

331,000

1975 CASELOAD T O T A L

1980 Immigrant visas issued:

Immigrant visas refused:

CASELOAD: Subtotal

Nonimmigrant visas issued:

Nonimmigrant visas refused:

CASELOAD: Subtotal

$7,318,000$

1980 CASELOAD T O T A L

$3,661,000$

$\underline{4,046,000}$

333,000

110,000

443,000

$6,735,000$

583,000

$\ldots \ldots \ldots \ldots \ldots \ldots \ldots \ldots \ldots \ldots \ldots, 761,000$

* In smaller American consulates overseas persons occupying foreign national positions sometimes do consular work.

\section{TRAINING FOR FOREIGN SERVICE OFFICERS:}

6.5 weeks basic training at Foreign Service Institute, Rosslyn, Virginia

5 weeks consular training, including visa, and all services at FSI.

2 weeks consultation training at "country desk" of Department of State, reads, observes, consults as "apprentice".

20-24 weeks language training in one specific language at FSI, and continues to study language at overseas post.

Source: Mike Hancock, Executive Office, Consular Affairs, U.S. Dep't of State (Aug. 27, 1981). 


\section{Estimates of Aliens Illegally Residing in the United States for VARIOUS DATES IN THE 1970S}

\begin{tabular}{|c|c|c|c|}
\hline $\begin{array}{l}\text { Date of } \\
\text { Estimate }\end{array}$ & $\begin{array}{c}\begin{array}{c}\text { Estimate } \\
\text { (in millions) }\end{array} \\
\end{array}$ & Comments & $\begin{array}{l}\text { Source and } \\
\text { Publication Date }\end{array}$ \\
\hline 1970 & 1.6 & Mexican-origin population only & Goldberg (1974) \\
\hline 1973 & $\begin{array}{c}3.9 \\
(2.9-5.7)\end{array}$ & $\begin{array}{l}\text { Ages } 18 \text { to } 44 \text { only. The numbers in } \\
\text { parentheses represent rough } 68 \text {-percent } \\
\text { confidence limits }\end{array}$ & $\begin{array}{l}\text { Lancaster and } \\
\text { Scheuren (1978) }\end{array}$ \\
\hline 1975 & 8.2 & $\begin{array}{l}\text { The Lesko report also contains an estimate of } \\
5.2 \text { million for the Mexican-origin population }\end{array}$ & $\begin{array}{l}\text { Lesko Associates } \\
(1975)\end{array}$ \\
\hline 1975 & $0.6-4.7$ & $\begin{array}{l}\text { Illegal white male population, ages } 20 \text { to } 44 \\
\text { only }\end{array}$ & Robinson (1980) \\
\hline 1975 & $0.4-1.2$ & $\begin{array}{l}\text { Net illegal immigration of Mexican-origin } \\
\text { population, } 1970-75\end{array}$ & Heer (1979) \\
\hline 1975 & $5.5-6.0$ & $\begin{array}{l}\text { Survey by districts. Rough estimates by } \\
\text { experienced immigration officers }\end{array}$ & $\begin{array}{l}\text { U.S. Immigration } \\
\text { Service, Commissioner } \\
\text { Chapman (1975) }\end{array}$ \\
\hline 1975 & 0.5 & $\begin{array}{l}\text { Annual flow estimate. Fraudulent entrants } \\
\text { study of Mexican border ports and major } \\
\text { international airports }\end{array}$ & $\begin{array}{l}\text { U.S. Immigration } \\
\text { Service, Commissioner } \\
\text { Chapman (1976) }\end{array}$ \\
\hline 1977 & $0.7-2.2$ & Mexican-origin population only & $\begin{array}{l}\text { Reestimation of } \\
\text { Mexico CENIET } \\
\text { (1979a) by U.S. } \\
\text { Census Bureau }\end{array}$ \\
\hline 1978 & $3-6$ & & Castillo, INS (1978) \\
\hline 1978 & $1.1-4.1$ & Total population, ages 20 to 44 & Robinson (1981) \\
\hline $\begin{array}{l}1978-79 \\
\text { (Dec.- } \\
\text { Jan.) }\end{array}$ & 0.4 & $\begin{array}{l}\text { Seasonal flow estimate. Mexican nationals } \\
\text { over } 15 \text { years of age working or looking for } \\
\text { work, without regard to legal status }\end{array}$ & $\begin{array}{l}\text { Mexico, CENIET } \\
\text { (1979b) National } \\
\text { Survey of Emigration }\end{array}$ \\
\hline 1978 & $3.5-6$ & $\begin{array}{l}\text { Speculative estimate of illegal alien } \\
\text { population, based on methodological } \\
\text { assessment of other studies listed }\end{array}$ & $\begin{array}{l}\text { Siegel, Passel, and } \\
\text { Robinson, Census } \\
\text { Bureau (1980) }\end{array}$ \\
\hline 1978 & .6 & $\begin{array}{l}\text { Speculative estimate of net annual inflow of } \\
\text { long-term illegal workers, } 75 \% \text { Mexican }\end{array}$ & $\begin{array}{l}\text { Edwin P. Reubens } \\
(1980)\end{array}$ \\
\hline 1979 & 1.1 & $\begin{array}{l}\text { Analytic estimate of Census-counted illegal } \\
\text { residents who entered } 1970 \text { to November } \\
1979 \text {, includes estimate of } 734,000 \text { Mexicans }\end{array}$ & $\begin{array}{l}\text { Robert Warren, } \\
\text { Census Bureau (1981) }\end{array}$ \\
\hline
\end{tabular}

Source: Adapted from Siegel, Passel \& Robinson, Preliminary Review of Existing Studies of the Number of Illegal Residents in the Uniled Slates, U.S. IMMIGRATION POLICY AND THE NATIONAL INTEREST: Appendix E to Staff Report of the Select Immigration and Refugee Policy, United States 13 (1980). 
